\title{
INDUSTRIAL ENGLAND IN THE
}

EIGHTEENTH CENTURY H. T. WOOD 


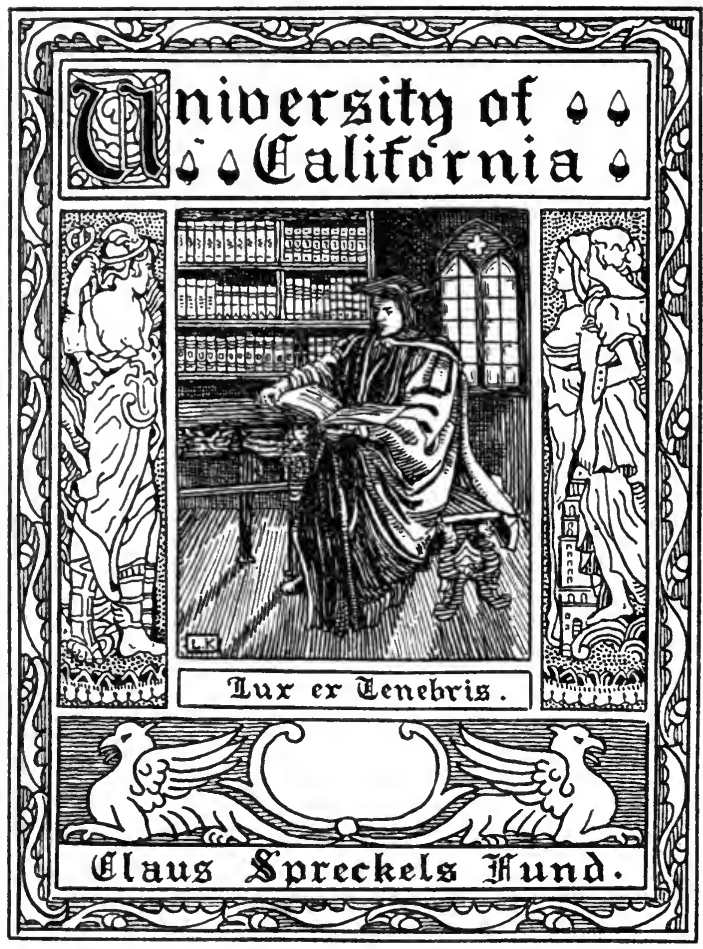




\section{Digitized by the Internet Archive in 2007 with funding from \\ Microsoft Corporation}


INDUSTRIAL ENGLAND IN THE MIDDLE OF THE EIGHTEENTH CENTURY 
. 


\section{INDUSTRIAL ENGLAND IN THE MIDDLE OF THE EIGHTEENTH CENTURY}

BY SIR HENRY TRUEMAN WOOD, M. A. SECRETARY OF THE ROYAL SOCIETY OF ARTS

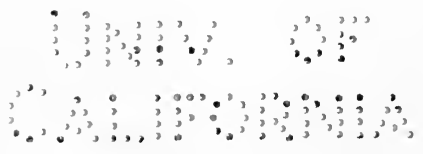

LONDON

JOHN MURRAY, ALBEMARLE STREET, W.

1910 
<smiles>[As]C1[As][As]=[As]1</smiles> 


\section{PREFACE}

This little book grew out of a paper read last April at a meeting of the Royal Society of Arts, in which the author endeavoured to describe the industrial condition of the country at the time of the foundation of the Society in 1754. The task turned out to be one of considerable interest, and the available material soon proved itself to be in excess of the limits even of a paper far exceeding the normal length.

The time dealt with was the period just preceding that of the Industrial Revolution. The prime factors of that revolution were the introduction of machinery, and the improvement of the steam-engine, but there were many other causes at work, chief among them the application of Science to Arts and Manufactures. The development of the factory system, the destruction of the old domestic industries of the country, the concentration of the people into cities, the changes thereby brought about in the conditions of agriculture-these are some of the effects, as they are also some of the causes, of the changes 
in the social, economic, and industrial life of the country. The growth of the iron manufacture and its effects on large districts of the North of England, the development of mining, are other effects, bringing in their train still further changes. How far these rapid and extensive alterations in the conditions of production affected men's minds, and how far they were the result of developed-or modified-mental capacity, is a question too large for consideration here; but if it be worth argument, material for the discussion may be provided by a general view of things as they were when the change was impending, or had indeed begun.

Hence it appeared possible that an account of the conditions which led to or accompanied the change from the old mercantile system under which industry was officially controlled and regulated, to the modern method of "laissez faire" and unrestricted competition, might interest others than members of a Society whose establishment was an indication of the tendency of the time, and whose success has certainly justified the intentions of those who established it. With this idea some considerable additions were made to the original paper, and it is now issued in its present form.

The Industrial Revolution in England has not indeed attracted the same attention as the contemporary Political and Social Revolution in 
France, but it has of course been adequately described by historians, who have appreciated the interest of the subject and the importance of the changes involved. Nobody, however, has yet taken the trouble to prepare a technical account of each industry and to describe it with sufficient detail to enable a comparison to be drawn between its condition then and its condition now. That has been the endeavour of the present writer, who, if he cannot profess an expert knowledge of any single manufacture, has been obliged for many years past to familiarise himself to some extent with the science and technics of them all, and to make a special study of the history of invention in England. $\mathrm{He}$ hopes, therefore, that the present treatise may be of use as ancillary to the work of the historians of the eighteenth century, and as containing, in a collected form, information now for the most part scattered about in trade and local histories. In such work no claim can be made for originality. The information is all available somewhere, for those who know where to look for it; but perhaps not very many do know where to look, or would care for the trouble of the search. In all cases acknowledgment has been made of the sources from which information has been derived, and references are given, for the benefit of any who desire ampler knowledge.

The aim of the writer has been in every case 
to describe the state of each industry as it existed in the year 1754 or thereabouts, but it has generally been necessary, for the sake of intelligibility, to deal to a certain extent with its earlier history, and its later development. Perhaps the treatment has not always been as uniform as it should have been, but some attempt has been made to devote more space to the less familiar subjects, and to treat in more summaly fashion those which have already been sufficiently dealt with by previous writers.

Some changes have been made in the arrangement of the different sections, and some fresh matter has been added, but on the whole the book retains the original form in which it was first presented to the audience of the Society of Arts. It has been thought well to preserve the introductory chapter, though its contents have but little of an industrial character. It was meant to indicate very briefly the general condition of the country in 1754, and it may serve the same purpose still.

It would be hopeless to expect that, in dealing with such a variety of technical subjects, there have not been a good many mistakes. If such blunders are less numerous than they might have been, it is due to the friendly criticism to which the proofs of the original paper were subjected. The writer desires specially to acknowledge the help he received from two old 
friends, Mr R. B. Prosser, formerly librarian of the Patent Office, and Mr H. B. Wheatley, for many years assistant secretary of the Society of Arts. Sir William White contributed the section on shipbuilding. The late Mr Lewis Day, Mr William Burton, Mr Seymour Jones, Mr Knight Clowes, Mr John Cross, Professor John Millar Thomson, Mr William Whitaker, Mr Frank Cundall (the secretary of the Institute of Jamaica), Mr E. W. Hulme (the librarian of the Patent Office), Mr Mervyn Macartney (the architect to St Paul's Cathedral), and Mr Ernest Pullan (of Messrs Barclay, Perkins \& Co.) have all helped most kindly in different sections of the book. Mr Henry Tedder, the librarian of the Athenæum, has saved the writer much labour by his frequent and valuable suggestions, and $\mathrm{Mr}$ G. K. Menzies, the present assistant secretary of the Royal Society of Arts, has rendered useful aid in the revision of the proofs.

Royal Soctety of ARts, August 1910. 
. 


\section{CONTENTS}

\section{CHAPTER I}

Introductory-Literature-Art-Architecture - Science-

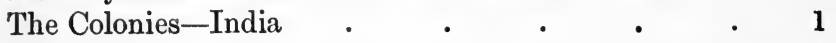

\section{CHAPTER II}

The Industrial Revolution-Motive Power and its Applications-Machine Tools-Roads-Canals

\section{CHAPTER III}

Wool-Cotton-Calico-Printing, Dyeing, etc.-LinenSilk-Hemp : Rope-making, etc.

\section{CHAPTER IV}

Iron-Copper and Brass-Lead-Pewter-Gold and Silver-Coal-Quarries and Stone-mining $\quad . \quad$. 73

\section{CHAPTER V}

Glass - Pottery and Porcelain -Watchmaking - Paper-

Printing and Bookbinding-Furniture, Carpets, etc. . 101 xi 


\section{CHAPTER VI}

Brewing - Distilling - Tanning - Candles and Soap-

Salt - Saltpetre - Gunpowder - Alum - Copperas Sulphuric Acid-Sugar-Tobacco $\quad$. $\quad$. 129

\section{CHAPTER VII}

Shipbuilding and Shipping-Fishing-Agriculture-Minor and Miscellaneous Industries-Patents for Inventions

- - Banking-Conclusion . . . . . 158

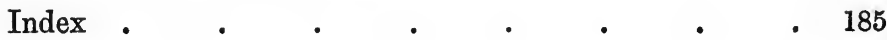




\section{INDUSTRIAL ENGLAND IN THE MIDDLE OF THE EIGHTEENTH CENTURY}

\section{CHAPTER I}

Introductory-Literature-Art - Architecture - Science - The Colonies-India

WHEN the Society of Arts was founded in 1754, the New Style had been established for not much more than a year, since it was in September 1752 that the eleven days, whose loss was so bitterly denounced by the people, were removed from the calendar. George II. was nearing the close of his reign, which was to end six years later. The last Jacobite rising had a few years before been successfully put down, and the Hanoverian succession was firmly established. The country was enjoying an interval of peace between the treaty of Aix-la-Chapelle (1748) and the breaking out of the Seven Years' War (1756). There was a pause in the complicated series of wars that devastated Europe, mainly on questions of successions and dynasties, in which for the most part England had small 
interest, and in which she had but too often been embroiled against her own desires. Her supremacy at sea had been established, despite the remnant of Spanish claims to dominion in the South Seas. The long rule of Walpole was over (he resigned office in 1742, and died in 1745). Pitt had been in office and in opposition, but was not yet in power. The country was prosperous and rich, ready to start on the career of manufacturing and commercial success which, by means of the marvellous development of industrial machinery and by aid of the imported riches of India, converted England within a span of fifty or sixty years from a pastoral country into the workshop and the emporium of the world. ${ }^{1}$

\section{LITERATURE.}

The great writers of Queen Anne's time had all passed away. Pope survived till 1744, and Swift for a year longer. Johnson had just finished his Dictionary, which was published in

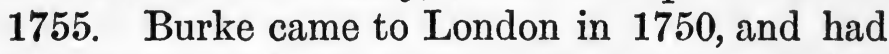
yet his reputation to make. Gray had made his,

1 The history of England in the eighteenth century has been written once for all by Lecky, and it seems almost superfluous for one who attempts to deal with a small fraction of that history to acknowledge indebtedness to a source so obvious. It may perhaps be hoped that some of the technical details which follow will serve to illustrate those chapters of the history which treat of the industrial progress of England in the latter part of the century. 
for he was offered, and declined, the Laureateship in 1757. Collins died unappreciated in 1759, and Shenstone, then appreciated but now forgotten, in 1763. Richardson published his last book, Sir Charles Grandison, in 1753, and Fielding, who died in the year in which the Society was founded, his Amelia in 1751. Smollett, whose Roderick Random had appeared in 1748, was busy writing. Goldsmith was still a bookseller's hack, the Vicar (written in 1761) not having been published till 1766, after the author had attracted attention by his Traveller. Sterne was only known as a writer of sermons; Tristram Shandy began in 1759. Horace Walpole (who was born in 1717) had not yet begun to write, or at all events to publish. It was in 1757 that he set up at Twickenham the private press from which most of his works were originally issued. John Home wrote the once famous tragedy of Douglas in $\mathbf{1 7 5 4 .}$ Percy's Reliques appeared in 1765. Hume began to publish his History in 1754, but Gibbon had only just left Magdalen ; and it was not till ten years later that he formed the plan of The Decline and Fall, the first volume of which appeared in 1776. Adam Smith was a Professor at Glasgow, not yet even contemplating The Wealth of Nations. Arthur Young was younger still, being a lad of thirteen in $\mathbf{1 7 5 4}$. 


\section{ART.}

"At the commencement of the eighteenth century in England there was no taste or feeling for art whatever." 1 The same remark applies almost equally well to the end of the first half of the century. Hogarth's name alone shines out, and Hogarth had to wait for a posthumous reputation which his contemporaries were incompetent to award. In 1754 Hogarth painted his largest, and what some people consider his best, pictures, the four scenes of "The Election." His last plate was published in 1764, the year of his death.

The English school of painting was not yet born, though some of those who made it were. It was this school which rendered possible the establishment of the Royal Academy (1768), and owed its own development and its own growth to that great institution. Reynolds, a young man of thirty, lately returnedlfrom Italy, had started on the career which rapidly led to fame and to fortune. West did not come to London till 1764, and was not yet a Court favourite. James Barry, to whom the Society of Arts owes a debt of gratitude, and whose name the Society has in return preserved from oblivion, appeared here a year sooner than West. Romney

${ }^{1}$ Hodgson and Eaton, The Royal Academy and its Members, p. 2. 
was a year earlier still. All were alike as yet unknown. Gainsborough, a little older than any of the three last named (he was born in 1727), was living happily at Ipswich with his young wife, busy painting, but he did not come into his own till after the establishment of the Royal Academy. Cosway was a boy of fourteen at Shipley's Drawing Academy in the Strand.

Engraving was in a poor state at the period of the foundation of the Society, and when Hogarth wanted assistance in engraving his pictures, he had to appeal to Frenchmen. John Boydell (1719-1804) changed all this, and formed a school of first-rate engravers, including Woollett, MacArdell, Earlom, Thorpe, Heath, Valentine Green, and others. He established a great continental trade in English engravings. The first engraving of importance published by Boydell was Woollett's plate after Wilson's Niobe in 1761, which Mr Cosmo Monkhouse described in the Dictionary of National Biography as being, with the exception of Hogarth's prints, "the first important engraving by a British engraver after a British painter."

In sculpture we may look in vain at this particular date for any artist above mediocrity. Nollekens (born 1737) was a lad of seventeen. John Bacon was three years younger. Flaxman was born the year after the Society was founded. To judge from the monuments of Westminster 
Abbey in the middle of the eighteenth century, the art was in a poor state, though the works of Roubiliac (1695-1762) were far above mediocrity; in fact, however much his "Frenchiness" may be condemned, he was a genius.

Rysbrach (1693?-1770) and Scheemakers (1691-1770) both produced fine busts-and Wilton, who practised in London from 1755, may be mentioned.

\section{Architecture.}

"The history of architecture in England during the eighteenth century, if not characterised by anything so brilliant as the career of either Jones or Wren, is marked in the beginning by the daring originality of Vanbrugh, and closes with the correct classicality of Chambers." I

Chambers was the architect of Somerset House (designed 1775), "undoubtedly the greatest architectural work of the reign of George III." ${ }^{2}$ The most popular and the most original architects of the time were the Brothers Adam, who may be said to have become fashionable by the middle of the century, and who continued to work till the century was almost over. (Robert died in 1792.) The House of the Society of Arts was built by them in 1774. George Dance the elder (1700-1768) built the Mansion

1 Fergusson's History of the Modern Styles of Architecture (1891), vol. ii., p. 53.

${ }^{2}$ Fergusson, p. 62. 
House in 1739, and the younger Dance (17411825) in 1770 rebuilt Newgate, "which, though only a prison, and pretending to be nothing else, is still [1891] one of the best public buildings of the metropolis." 1 Gibbs (1682-1754), the architect of St Martin's-in-the-Fields, may also be mentioned. The latter half of the century was the time of the classical revival, though the first suggestion of the much later Gothic revival which succeeded, is credited by $\mathrm{Mr}$ Eastlake ${ }^{2}$ to the influence of Horace Walpole and his writings. It was in 1747 that he purchased Strawberry Hill, and a few years later that he started rebuilding the villa in accordance with his own notions of Gothic art.

Fergusson tells us that some two hundred "great manorial mansions" were erected in England and Scotland during the century, all in the classical style, and all, in his opinion, of small artistic merit. So we may consider it a great building age if not one of great architecture.

\section{Science.}

Science, about the middle of the eighteenth century, was not in a condition of active progress either in England or abroad. The time was not a happy one, either for science or for scientific

${ }^{1}$ Fergusson, p. 68. Dance's Newgate has now of course disappeared.

${ }^{2}$ The Gothic Revival (1872), p. 42. 
men. International intercourse was impeded by wars, national progress was hindered by political differences. The great days of Newton, Hooke, Boyle and Halley were past. Those of the founders of modern science were yet to come. Cavendish had just left Peterhouse. In 1756 he discovered hydrogen, and it was not till 1784 that he (and Watt) discovered the composition of water. Priestley had not yet turned his attention to natural philosophy-his scientific work began in 1758. Banks, who ruled the Royal Society for so many years, was in 1754 a boy of eleven. Gilbert White (b. 1720) commenced his Garden Kalendar in 1751, but he did not make Pennant's acquaintance till thirteen years later, when he started the famous correspondence which formed the groundwork of the immortal Natural History of Selborne. Franklin had completed and made public his epoch-making experiments, and (in 1752) proposed to protect buildings by the lightning-rod. Black, the friend of Watt, and the enunciator of the principle of "latent heat," produced his first important work as a thesis for his M.D. degree in $\mathbf{1 7 5 4}$.

In the earlier part of the century, the power of mathematics in enabling us to grapple with the most abstruse problems of nature was first clearly demonstrated. In the latter part the foundations were laid, on which the modern science of chemistry was built. The intervening 
years were not characterised by any marked progress in abstract science.

The Royal Society (to which a charter had been granted in 1662) was now firmly established at the head of British science. Though it was still deemed a suitable object for the occasional shafts of humorists, ${ }^{1}$ and though it was sometimes attacked by quacks, whose pretensions it declined to countenance, it was recognised and respected by all serious students of science, both at home and abroad. It had gathered to itself the best thought of the country, and was affording to what would otherwise have been the isolated efforts of scientific pioneers, the advantage of co-ordination and co-operation.

Scientific attention was then principally, though by no means exclusively, directed to astronomy and to exploration. The transits of Venus of 1761 and 1769 had been predicted by Halley, and great importance was attached to their proper observation. An Act of 1743 offered a reward of $£ 20,000$ for the discovery of a North - west Passage, and later the discoveries of Captain Cook received full scientific recognition by the award of the Copley Medal.

Perhaps no better indication of the state of

1 Samuel Butler and Sir William Temple were among the more eminent of those who found the proceedings of the Royal Society fit subject for ridicule in earlier days. Horace Walpole records a joke made at its expense, but not by himself. 
scientific progress at any time in England could be found than is provided by the list of the Royal Society's Copley Medallists. In 1731 and 1732 the medal was awarded to Stephen Gray, ${ }^{1}$ the ingenious electrician who contrived a method of sending signals by means of frictional electricity, and who made therefore the first electric telegraph. It must, however, be added that the award seems to have been rather in the nature of acknowledgment of a skilful experiment than of appreciation of an important discovery. Bradley received the medal in 1748 for his discovery of the aberration of light, and Harrison in 1749 for his chronometer. In 1753 it was given to Franklin for the lightning-rod, and in 1758 to Dollond for his achromatic telescope.

The nature of these last three awards shows the tendency of the time towards practical, rather than towards abstract science, and justifies the conclusion that the leaders of scientific thought of those days were working rather for practical results than for the advance of theoretical knowledge.

\section{The Colonies.}

In the year 1754, the word colonies meant only "His Majesty's Colonies and Plantations abroad" in America and in the West Indies.

${ }^{1}$ Gray it was who first proposed the theory of positive and negative electricity. 
Captain Cook, the results of whose later voyages were to extend so widely the British Empire, was still a common sailor in the navy. In North America, British rule extended along the coast from Nova Scotia to Georgia, and as far inland as the colonists could hold the country against the Indians and the French. France still owned Canada, from which-only five years later-she was to be thrust out by Wolfe after his defeat of Montcalm (1759). Louisiana was also hers, and she possessed a shadowy claim to the vast inland spaces watered by the Mississippi, after the adventurous journey of $\mathrm{La}$ Salle, in 1682. Florida was still Spanish, and so was California. Newfoundland had been British since 1583. The Hudson's Bay Company had long held its own against the French, aided by the advantage of its possessing a sea-route into the interior of the country, since the "navigation of Hudson's Straits, with all its dangers, was a very preferable route to the long land journeys on which the French were thrown back by the insufficiency of their marine." 1

During the constant wars many of the Hudson Bay forts changed hands more than once, but at the date of the battle of Quebec there were certainly numerous forts or factories held by the Company, ${ }^{2}$ even if there was no regular settlement or colony.

${ }^{1}$ Cunningham's English Industry and Commerce, vol. i., p. 280.

2 Causton and Keane, Early Chartered Companies, p. 166. 
Our West Indian possessions then included Barbados, Jamaica, Trinidad, Antigua, and the Bahamas, with a settlement in Guiana on the mainland. The Bermudas also belonged to us.

In 1754, the Bermuda Islands had been British for a century and a half; Barbados, Antigua, St Kitts, Nevis and Montserrat for about a century and a quarter; the Bahamas and Jamaica for a century, and the Virgin Islands for a little less.

The land that is now known as British Honduras, though not formally recognised as British till 1798, was in the hands of British subjects who had become logwood-cutters when piracy was no longer profitable, and who in that very year (1754) successfully repulsed an attempt made by Spain to oust them.

By the peace of Aix-la-Chapelle

(1748) Dominica, St Vincent, St Lucia and Tobago were recognised as neutral, in the possession of the native Caribs.

Of the British possessions the most settled and most valuable were Jamaica, which exported sugar, rum, coffee, and pimento (allspice), with Barbados and Antigua, the foremost of the sugar islands. ${ }^{1}$

1 According to Long's History of Jamaica (1774), about half the cultivated land in Jamaica was devoted to sugar-growing. Excluding land used for raising stock and growing crops for local consumption, the next largest area was given up to coffee-growing, an industry which seems to have been started not very long 
The African Company held certain factories on the Gold Coast which, after many vicissitudes, have developed into the British West African Colonies. St Helena was held by the East India Company. ${ }^{1}$

\section{INDIA.}

In India the struggle between France and England for the domination of the country was nearing its close. The first sign of the tide having turned was the defeat of Dupleix by Clive at Arcot (1751), though the question as to which of the two great rivals should rule India was not finally settled for another ten years, until the defeat of Lally and our capture of Pondicherry. Plassy, too (1757), was not yet fought, and it was by the defeat of Surajah Dowlah that the foundation of our Empire in Hindostan was firmly laid. Henceforth the East India Company, no longer traders on sufferance, depending on the good-will of the princes of the country, were themselves the

before (in a list for 1751 coffee is not mentioned) and to have developed rapidly. Then comes cotton, and after this, in much smaller proportion, pimento and ginger. Tobacco is not mentioned.

1 The eighteenth century was indeed the time of the "Expansion of England," but the discussion of the great questions with which Sir J. R. Seeley dealt would be out of place here. It was at a little later date than the one with which we are specially concerned that England lost her most important colonies, and discovered in the Southern Seas the great lands with which that loss was made good. 
rulers of India. It was now that they entered on the great dominion they were to hold for a hundred years, till it outgrew their capacity, and had in our own days to be handed over to the Crown. 


\section{CHAPTER II}

The Industrial Revolution-Motive Power and its ApplicationsMachine Tools-Roads-Canals

\section{The "Industrial Revolution."}

IT is not very easy for us now to understand how backward England was, in the middle of the eighteenth century, in all those arts and sciences which have since made her rich and powerful, or to realise that all her industrial progress has been compressed into the space of, at most, a hundred and fifty years.

"During the period of history known as the Middle Ages, the industrial attainments of the English were far below the level of their Continental rivals-France, Germany, Italy, Spain, and the Low Countries. Moreover, throughout Europe, progress in the manufacturing arts is found to be due, not so much to individual experimental efforts, as to the slow infiltration of improved processes, the source of which is ultimately traceable to the more advanced civilisation of the East." 1

1 E. W. Hulme, Law Quarterly Review, No. xlvi., April 1896. 
The statement is true for times long subsequent to the mediæval. In the middle of the eighteenth century England was not, to any extent, a manufacturing country, though it produced most of the goods required for its own population, and exported a certain proportion of its surplus manufactures. ${ }^{1}$ Its most important industry was agriculture. Lecky tells us that it was only in the latter half of the century that England ceased to be a wheatexporting country, ${ }^{2}$ and on another page he speaks of the same period as "the most memorable in the industrial history of England." This indeed is true, since it was the period of the "Industrial Revolution," s during which England developed from an agricultural country, with no manufactures beyond those required for the supply of its own population, into the workshop of the world. Precisely the same view is taken by Green, ${ }^{4}$ who, after remarking on the sudden change by which the country-abandoning her

1 "Up to 1765, England had been an exporting country in divers agricultural products."-Thorold Rogers, in Six Centuries of Work and Wages, vol. ii., p. 485.

${ }^{2}$ Lecky's England in the Eighteenth Century (First Edit.), vol. vi., p. 211.

${ }^{3}$ The credit of inventing this phrase, which in two words summarises the history of half a century, may fairly be ascribed to Arnold Toynbee, though before him J. R. Green had spoken of an "Industrial Revolution." Subsequent writers have adopted it and employed it freely.

${ }^{4}$ History of the English People, vol. iv., p. 278. 
older agricultural character-devoted herself to the development of new industrial forces, goes on to say :-

"Though England already stood in the first rank of commercial nations at the accession of George the Third, her industrial life at home was mainly agricultural. The growth of her manufactures was steady, but it continued to be slow; they gave employment as yet to a small part of the population, and added in no great degree to the national wealth."

To fix a precise date for the beginning of the Industrial Revolution is impossible. Its origin might be traced back to the incoming of Huguenot fugitives, or to the first use of Newcomen's engine to pump water out of mines, or to the first smelting of iron with coal. Or it might be said to commence with Watt's improvement in the steam-engine, or with the first attempts to spin or weave by machinery. The fact is that all these great industrial developments were interdependent, and all had a reciprocal influence one upon another. Coal could not have been won without the steam-engine. The steam-engine could not have been worked without coal. Automatic machinery could not have been driven without steam power, the engine could not have been constructed without machine tools. Neither 
engine nor machine could have been developed without iron, and the iron could not have been wrought without mechanism and power. It was one great cycle of interacting and reacting forces, no one of which could have come to perfection without the aid of the rest. Who shall say when the change began, when it was completed, or even when it was first recognisable? But the mid-point of the eighteenth century may fairly be taken as a datum line between the old and the new. The old industrial systems had reached their fullest development, and had even begun to decay. Signs of change were in the air. Looking back after a century and a half we can see them, but they were not perceptible at the time or until long after. At this critical point the Society of Arts was founded. Its foundation indeed was a sign of the times, one of the signs that men's minds were being influenced by the coming changes, though they themselves were not even dimly conscious of any impending revolution.

\section{Motive Power and its Applications.}

The two essential needs of industrial manufacture are power and means of communication : power to render possible manufacture on the larger scale; means of communication by which raw material may be collected and the finished products distributed. In England-as indeed 
elsewhere - neither was in existence till long after the middle of the eighteenth century. The only power available was that of flowing water, wind, and animals. Wind and water mills were very ancient inventions, but not much is known about their early history.

Rankine, in the introduction to his treatise on the steam-engine, says:- "It would be vain to attempt to trace the history of the application of muscular power, water power, or wind power to the driving of machinery." It is, however, certain that when there was little machinery to drive, there was no great need for prime movers to drive it, and the applications of the three sources of power were not very numerous. Wind and water mills were used for grinding corn and pumping or raising water. Thus, the force of the tide running out through the arches of old London Bridge, was utilised to supply London with water from the river. Wind mills were employed for drainage purposes in Holland and in the English Fens. They were also, before the problem of mine-drainage was solved by Newcomen's steam-engine, used to clear mines from water, a task which their intermittent service performed but indifferently. Attempts were made to utilise wind power for other purposes in collieries. Yalden, in his poem, ${ }^{1}$

${ }^{1}$ Quoted by Galloway in his History of Coal Mining, p. 66. 
speaking of the inventions of Sir Humphrey Mackworth, the ingenious and successful Welsh colliery-owner, at the very beginning of the century, says :-

"The winds, thy slaves, their useful succour join, Convey thy ore, and labour at thy mine."

Tilt hammers, used in making iron, were driven by water. Tappets on the shaft of a water-wheel depressed one end of a pivoted lever, the other arm of which carried a heavy hammer-head; the weight of this when the short arm was released by the passage of the tappet, caused it to fall heavily on the iron ingot.

The stocks or hammers of the fulling mills used in cloth-making, as previously mentioned, were driven by water-wheels, and were presumably actuated by similar mechanism.

Saw-mills for cutting logs into planks were used in some parts of the continent in the seventeenth century and probably earlier. These were driven both by wind and by water. Smiles ${ }^{1}$ says that the first saw-mill in England was erected by a Dutchman near London in 1663, but was shortly abandoned in consequence of the hostility of the workmen. He does not, however, give any authority for this statement, and it was

Thomas Yalden (1671-1736) is included in Johnson's Lives of the Poets.

1 Industrial Biography, p. 165. 
not till more than a hundred years later, in 1767, that the newly founded Society of Arts encouraged and assisted John Houghton to set one up at Limehouse, driven by a wind mill. This was destroyed by a riotous mob, but a second was erected and worked satisfactorily. ${ }^{1}$

"Mills," either water or wind, were also used for grinding corn, crushing ores and other materials by means of edge-runners, horizontal mill-stones or rollers, rolling out plates for making tin-plate, working bellows for blowing furnaces, operating the stamps for pulping rags for making paper, working "slitting mills" for cutting metal into strips, drawing wire, and doubtless for other like purposes.

The only other known apparatus for the utilisation of natural forces was perhaps the ancient smoke-jack, which, it is said, can be traced back to the twelfth century. ${ }^{2}$ In 1728 John Payne

${ }^{1}$ Dossie, Annals of Agriculture, etc., vol. i., p. 123. Beckmann's History of Inventions. Smiles, Ind. Biog.

2 The invention of the smoke-jack has been attributed to Jerome Cardan, the celebrated mathematician, astrologer, and physician (1501-1576); but it is difficult to find any authority for the idea, though Thurston in his work, hereafter quoted, speaks of Cardan as being the inventor. Henry Morley, in his excellent biography, refers to various mechanical devices which were mentioned in the voluminous writings of this extraordinary character, but says nothing of the smoke-jack. Chambers' Cyclopoedia (1751) speaks of the "ventiducts of Cardan" as a device for curing smokey chimneys, and Morley mentions an appliance of this sort. A writer (J. Jopling) in the Mechanic's Magazine of 28th June 1845 (vol. xlii., p. 444) states that a smoke-jack was represented in a 
patented an apparatus (No. 505) which was really a big smoke-jack. By this he proposed to utilise the draught in furnace chimneys for working machines. The suggestion is not without interest, but certainly the amount of power obtained would be inconsiderable.

Animal power was applied in very early times for raising water. The horse gin was used for raising coal in mines, and wheels, such as the one still shown at Carisbrooke Castle in the Isle of Wight, turned by a horse or a donkey within them, were used for raising water from wells. A similar wheel on a smaller scale was worked by the turnspit. The use of animal power (and also of water power) for driving the spinning machines of Paul and Wyatt, and of Lombe, is referred to later. ${ }^{1}$

It would doubtless not be difficult to discover a few more examples of the application of power to industrial purposes, but they would probably not be either numerous or important. Those mentioned may, at all events, serve to show what the condition of things was at the end of the first half of the eighteenth century. It was very soon to be altered.

"At the beginning of the eighteenth century every element of the modern type of steam-engine picture known to be older than 1350 , but does not mention the name of either picture or artist.

${ }^{1}$ See pp. 53 and 67. 
had been separately invented and practically applied. The character of atmospheric pressure, and of the pressure of gases had become understood. The nature of a vacuum was known, and the method of obtaining it by the displacement of the air by steam, and by the condensation of the vapour, was understood. The importance of utilising the power of steam, and the application of condensation in the removal of atmospheric pressure was not only recognised, but had been actually and successfully attempted by Morland, Papin, and Savery." 1

It was in 1698 that Thomas Savery obtained his patent. A year later his invention received the approval of the Royal Society, and in 1702 he published his Miners' Friend, a pamphlet containing a description and drawings of his engine. Although in the patent-grant the engine is described as being suitable for " occasion-

1 History of the Steam Engine, R. H. Thurston (Second Edit.), 1879, p. 55. This book contains the best account known to the writer of the early history of the steam-engine, at all events down to the time of Watt. Its author was a distinguished American engineer, and Professor of Mechanical Engineering at the Stevens Institute of Technology. He died in 1885. R. L. Galloway's The Steam Engine and its Inventors (1881) is also a useful book. Stuart's History of the Steam Engine (1824), and his Anecdotes of the Steam Engine (1829) are of peculiar interest and value because of their date. They were the earliest books of their sort, and have preserved a great deal of information which must otherwise have perished. Their author's name was really Robert Stuart Meikleham (at least that was what he called himself in the last years of his life). He published another book, in which he used the pseudonym of Walter Bernan. 
ing motion to all sorts of mill-works," it was really only a steam pump of the nature of the modern pulsometer. How far it was brought into practical use is doubtful. It was certainly tried at one or two mines, and it was successfully used to pump water for the supply of Campden House, Kensington. ${ }^{1}$

Savery's pretensions to an important share in the invention of the steam-engine have often been disparaged, perhaps because the practical success of his engine compared but ill with the claims he made for it, nor is it certain that he was not to some extent anticipated by the Marquis of Worcester. ${ }^{2}$ Still, it seems most probable that he was the first man to construct a real working engine, capable of raising water to a height at all events of some 60 feet, and, if properly made, of working continuously and with regularity.

Savery's engine, however, at its best was but an imperfect contrivance, and it was Newcomen

1 Pictures and descriptions of Savery's engine are given in many books on the steam-engine, including the two above referred to. His Miners' Friend was republished by the Commissioners of Patents in 1858, as one of a series of reprints of scarce pampllets descriptive of early patented inventions.

${ }^{2}$ Not very much is known about the Marquis of Worcester's "Stupendious Water-commanding Engine." It is mentioned but not described in his quaint Century of Inventions (1663), but there is some evidence that it may have been like Savery's. This evidence, such as it is, is given in full in Dirck's Life of the Marquis of Worcester (1865). 
who really brought the steam-engine into the form in which we know it. His improvements were probably suggested by the work of others. $\mathrm{He}$ may have learnt much from Hooke, who was familiar with the researches of Papin and Huyghens, and who certainly discussed with Newcomen the best methods of utilising the power of steam. But the practical result was that he constructed in $\mathbf{1 7 1 2}$ an engine of the modern type, with a cylinder and piston and a separate boiler, capable not only of doing the work required, pumping water out of mines, but also, if the inventor had only realised the fact, of imparting motion direct to mill-machinery. The Newcomen engine at its best was clumsy, roughly made and most wasteful of fuel, but it accomplished the work required of it for half a century without any important alterations, and there still are, or were a very few years ago, ${ }^{1}$ one or two ancient Newcomen engines doing more or less well the work to which they had been set in the lifetime of the inventor. The engine, however, as it left Newcomen's hands, was never applied to any other purpose than that of pumping, and perhaps it was really fit for nothing else. To render it suitable for the work of giving equable and regular propulsion to machinery required a genius greater than Newcomen.

${ }^{1}$ See a paper on the Newcomen Engine by H. Davey, Proc. Inst. Mech. Eng., Parts 3-4, p. 655 (Oct. 1903). 
In 1754 , the year in which the Society of Arts was founded, Watt, then a lad of eighteen, went to Glasgow to learn the trade of mathematical instrument making. Ten years later, the historic model Newcomen engine was placed in his hands for repair. In $\mathbf{1 7 6 5}$ he conceived the idea of the separate condenser. In 1769 he took out his patent, but another seven years elapsed before he had, in 1776, his completed engines at work, and again another ten before the steam-engine passed from the colliery to the workshop, and in $\mathbf{1 7 8 6}$ began to drive the mills and the machinery of the world.

\section{Machine Tools.}

At the time with which we are concerned, such a thing as a machine tool was quite unknown. The lathe, of immemorial antiquity, had been developed both here and in France, the state it had reached in that country being well shown by Plumier's well-known treatise published in Lyons, in 1701. "In our country," says Professor Willis " the literature of the subject is so defective that it is very difficult to discover what progress we were making during the seventeenth and eighteenth centuries. A few scattered hints only can be collected."

Prof. Willis, however, refers to the earlier

${ }^{1}$ Lectures on the Results of the Great Exhitition of 1851 (edit. 1852), p. 306. 
treatise by Moxon (1680), published in this country. From these and other sources it is certain that the lathe was capable of turning out high class ornamental woodwork. It was "adapted to the production of oval figures, twisted and swash-work as it is called, and, lastly, of rose-engine work, etc." ${ }^{1}$ Anything more than this was beyond its powers until the slide-rest was invented.

Devices for clamping the cutting tool in a fixed position must have been employed, and indeed such devices are referred to in early books, but the first appearance of the slide-rest, according to Willis, dates from 1772. In that year complete drawings and details of an excellent slide-rest are given in Diderot's Encyclopédie, though the description is meagre. This, says Willis, not only anticipates Bramah's slide-rest of 1794 (it was really Maudslay's), but is distinctly superior to it. ${ }^{2}$

Willis says that little is known of the early history of the planing-machine, and defers its invention till well on in the nineteenth century. "The machine which Nicholas Focq contrived in

1 Willis, p. 305.

${ }^{2}$ Some interesting correspondence published by Dr Smiles as an appendix to the second edition of his Industrial Biography, seems to indicate that Henry Maudslay very probably derived the idea from two slide-rests which were used in certain machinery brought into Woolwich Arsenal from Holland about 1780 . 
1751, which has been called a planing-machine, has no title to the name or any resemblance to the modern engine." 1

In 1741 Hindley, a York clockmaker, showed Smeaton a screw-cutting lathe with change wheels, and long before this special machines were used by the clockmakers for cutting wheels and making fusees. These were all small tools, and the clockmakers seemed to have a monopoly of mechanical ingenuity.

Proposals for enabling machinery to do the work of human hands occasionally occur; thus about 1732 Wyatt, the inventor of the roller spinning - machine, endeavoured to make a machine for cutting files, but without success. It may, however, be fairly assumed that the first application of automatic shaping machinery on the large scale was the block-making machinery of Brunel, which was not set to work till the early years of the nineteenth century.

\section{ROADS.}

In the middle of the eighteenth century the means of intercommunication in England were

1 Willis, p. 313. Nicholas Focq's "machine à raboter le fer" is described in Machines et Inventions approuvées par l'Académie, vol. vii., p. 407. The date of the volume containing the description is 1777 , and the date at which the invention was "approved" was 1751. Focq is described as "Entrepreneur des machines-aेfeu, de Charleroy et de Conde." The plate is reproduced in Rennie's edition of Buchanan on Millwork (1841), and this may have been the source of Willis's information. 
sadly deficient. Macaulay, in the third chapter of his History, gives a graphic description of the English roads as they were in the time of Charles II., and Lecky tells us that they were little better a hundred years later. This opinion is confirmed by the fact that Defoe, writing at the beginning of the century, and Arthur Young, writing at the end of it, both speak in much the same terms of the country roads. The first Turnpike Act was passed in 1663, but, like most other improvements, the turnpike roads were unpopular and their extension bitterly opposed. All contemporary accounts agree as to the badness of the roads, or rather, tracks, by which passengers and merchandise were conveyed between even the most important towns. "On the best lines of communication the ruts were deep, the descents precipitous, and the way often, such as it was, hardly possible to distinguish in the dusk from the unenclosed heath and fen which lay on both sides." ${ }^{3}$ Six horses were required to drag the heavy coaches of the gentry, and their efforts had sometimes to be supplemented by teams of oxen. In all parts of the country it was the same: the roads near London were little better than those in Sussex, or in the west country, or in the north. Much travelling was still done on horseback. Stage-coaches there were, but they took a week or more 
between London or Edinburgh, according to the state of the weather. ${ }^{1}$ Smiles quotes the advertisement of a "flying coach" started in 1754, which was, "however incredible it may appear," to arrive in London four days and a half after leaving Manchester. From Glasgow to London was a fortnight, from Sheffield to London (in 1760) three days.

There is no doubt that the English roads in the reign of George II. contrasted unfavourably with the Roman roads in the time of Theodosius (fourth century A.D.), since at that date, according to Gibbon, "it was easy to travel an hundred miles a day along the Roman roads."

Travellers generally proceeded on horseback.

${ }^{1}$ Smiles' Engineers, vol. i., p. 196.

2 Decline and Fall, Chapter II. Gibbon's statement is based on the record of a journey by one Cæsarius, a magistrate, from Antioch to Constantinople-665 miles in five and a half days, or at the rate of 5 miles an hour. The journey was presumably made in the ordinary Rheda or Roman travelling carriage, a heavy and cumbersome vehicle compared with the English postchaise (see Becker's Gallus, English edition, 1866, p. 348), and by the use of relays of horses, which were regularly provided every 4 or 5 miles. A horseman would get over the ground faster. Probably the most rapid regular system of transport by means of horses was the Pony Express line, established in 1860 for the conveyance of mails across the western prairies of America, and carried on for about a year, until it was superseded by the telegraph. The riders travelled at the rate of 250 miles a day, or about 10 miles an hour, and over rough country, not on regular roads. There were, of course, relays of men as well as of horses. An account of the Pony Express is given in Mrs Wedmore's Life of Colonel Cody, "Buffalo Bill," The Last of the Great Scouts (1903), p. 69. 
James Watt rode from Glasgow to London; Brindley rode from Congleton to London and back; Dr Johnson, after his marriage, took his wife on a pillion from Birmingham to Derby.

After the rebellion of $\mathbf{1 7 4 5}$, General Wade's roads were made in Scotland, and "from that time, though slowly, the construction of the main high roads between north and south made rapid progress." 1 From 1760 to 1774 , no fewer than four hundred and fifty-two Acts were passed for making and repairing highways."

And there is abundant evidence that from about the middle of the century, the improvement in roads was great and rapid. Archdeacon Cunningham ${ }^{3}$ quotes a writer of $1767,{ }^{4}$ as contrasting the condition of the roads in his own time, with their state in the time of Queen Anne :-

"There never was a more astonishing Revolution accomplished in the internal system of any country, than has been within the compass of a few years in that of England. The carriage of Grain, Coals, Merchandise, etc., is in general conducted with little more than half the number of Horses with which it formerly was. Journies of Business are performed with more than double

${ }^{1}$ Smiles, vol. ii., p. 105.

2 Ibid., p. 206. Smiles' account of the blind road-maker, John Metcalf, is full of interest.

3 Vol. i., p. 537.

‘ Henry Homer, Enquiry into Public Roads, Cunningham, 537. 
expedition. Improvements in Agriculture keep pace with those of Trade. Everything wears the Face of Dispatch; every Article of our produce becomes more valuable; and the Hinge, upon which all the movements turn, is the Reformation which has been made in our Publick Roads."

It may, however, be taken as pretty certain that this improvement was only along the main lines of communication, and that the country roads generally were still in a very backward condition.

The carriages used during the seventeenth century were cumbrous and heavy. They were of necessity strong, or they could not have travelled over the roads to suit which they were built. Springs were introduced near the end of the century, and then carriages could be made of lighter build and of less weight, without losing strength. They consequently were gradually improved in construction and shape, though it was not till near the end of the eighteenth century that anything like the modern type of vehicle was produced.

In 1774, Burke travelled in a post-chaise from Malton in Yorkshire to Bristol, 270 miles, in forty-four hours, without stopping or sleeping. ${ }^{1}$ This would give a rate of 6 miles an hour, including time spent in changing horses.

${ }^{1}$ Morley's Life of Burke (1879), p. 74. 
In 1784, Palmer's mail-coaches were established, and the improvement, both in roads and in the vehicles which traversed them, went on, till the admirable coach service was established, which was only surpassed in our fathers' and grandfathers' time by the railway. ${ }^{1}$

And if the means for the transport of passengers were bad, those for the conveyance of merchandise were worse.

"The older main roads, which had lasted fairly through the Middle Ages, had broken down in later times before the growth of traffic and the increase of wagons and carriages. The new lines of trade lay often along mere country lanes which had never been more than horse-tracks, and to drive heavy wains through lanes like these was all but impossible. Much of the woollen trade, therefore, had to be carried on by means of long trains of pack-horses; and in most cases the cost of carriage added heavily to the price of production. In the case of yet heavier goods, such as coal, distribution was almost impracticable, save along the greater rivers, or in districts accessible from the sea." ${ }^{2}$

In many parts of the country trains of

1 There is a good deal of information about the carriages used in the eighteenth century in the course of Cantor Lectures on the History of Coachbuilding (Journal of the Society of Arts, vol. xxv., p. 116, etc.), by the late Mr G. A. Thrupp. Mr Thrupp mentions that the Lord Mayor's state coach was built in 1757.

2 J. R. Green, History of the English People, vol. iv., p. 278. 
pack-horses were still employed, and even on the main lines of communication goods could only be sent by slow and cumbrous waggons. Coal - as its name "sea-coal" implied - was almost entirely conveyed by sea, though a little earlier than the date in which we are interested, it still formed part of the burden of the packhorse. As late as $1753,{ }^{1}$ the raw wool and bale goods of the north of England were carried by pack-horses, which conveyed the chapmen's wares to the places where they were sold, bringing back the wool and other raw materials. Even after the improvement in roads was well advanced, pack-horses were frequently employed, and doubtless they were used to a larger extent in districts where the roads were still inferior. Corn was so carried, and even heavy materials, such as potter's clay, were transported part of the way by water and the rest of the journey by pack-horses, each horse carrying six balls of clay, three on each side. ${ }^{2}$

In 1760 Manchester goods were sent on pack-horses to London and Bristol, as well as to Liverpool, for exportation. ${ }^{3}$

\section{Canals.}

The origin of canals is unknown. They

1 Whitaker, quoted by Smiles, vol. i., p. 180.

${ }^{2}$ Meteyard's Life of Wedgwood, vol. i., p. 140.

3 Baines, History of the Cotton Trade, p. 111. 
probably existed in China and in Europe from a very early date. Locks are supposed to have been invented in the fourteenth century (by Leonardo da Vinci or another), and before they were available, the use of canals must have been very limited. The great Languedoc Canal, from the Bay of Biscay to the Mediterranean, was completed in 1681, but though, as Macaulay says, "the English of that day were in the habit of talking with mingled admiration and despair of the immense trench by which Lewis the Fourteenth had made a junction between the Atlantic and the Mediterranean," it was very nearly a hundred years before they tried to follow his example.

The navigable rivers of Britain had no doubt been used since Roman galleys first sailed up the Thames, and from an early date attempts had been made to improve and develop riverine communications. Various Acts of Parliament were passed, having for their object the improvement of navigable rivers. There were several proposals for connecting London and Bristol by means of the Avon and the Thames, uniting the limits of navigation either by causeways or by canals. Some schemes were carried out. The rivers Aire and Calder, in Yorkshire, were opened up to navigation in the early part of the eighteenth century, and a little later water communication between Liverpool and Man- 
chester was established by way of the Mersey and the Irwell. ${ }^{1}$

The long island coast-line also, to a large extent, facilitated communication between towns on the sea-shore or near the mouths of rivers. There was certainly considerable traffic by sea between London and the north, but it would appear that the inland water-ways of England played but a small part in the transport of either goods or passengers before the introduction of canals.

Unless the old Foss dyke and Caer dyke in Lincolnshire are Roman canals ${ }^{2}$ and not merely drainage or irrigation cuts, there was no such thing as a canal in this country until the public spirit of the Duke of Bridgewater and the engineering skill of Brindley were united in the construction of the first Bridgewater canal from Worsley to Manchester, which was opened to traffic in 1761. A very full and interesting account of the carrying out of this great engineering work, and of the completion of the system of canals of which it was the first, will be found in Smiles' Life of Brindley. ${ }^{3}$

The success of the Bridgewater canals led to a rapid development of canals throughout the country, a development, like that of the roads,

${ }^{1}$ Smiles, vol. i., pp. 300 et seq.

${ }^{2}$ Encyclopcedia Britannica, art. "Canals."

${ }^{3}$ Lives of the Engineers, vol. i. 
only checked in the following century by the introduction of railroads.

Dr Smiles' account of the circumstances which led the Duke of Bridgewater to conceive his great project, throws a vivid light on the state of transport and traffic in Lancashire and Cheshire at the time. Though Manchester was at the time the seat of a considerable manufacture of fustians, mixed stuffs, and small wares (tapes, webbing, leather laces, etc.), it yet suffered at times from famine.

"In winter, when the roads were closed, the place was in the condition of a beleaguered town; and even in summer, the land about Manchester itself being comparatively sterile, the place was badly supplied with fruit, vegetables, and potatoes, which, being brought from considerable distances slung across horse's backs, were so dear as to be beyond the reach of the mass of the population. The distress caused by this frequent dearth of provisions was not effectually remedied until the canal navigation became completely opened up." 1

This state of things was rapidly altered by the new system of canals. As a recent writer on the subject ${ }^{2}$ has remarked, inland water carriage "involved a complete revolution in the method of transport existing at that time, for

1 Smiles, vol. i., p. 343.

2 Edinburgh Review, April 1910, p. 276. 
by the close of the century, the country was much better provided with canals than it had been with roads at the beginning." The same writer fixes the great era of canal construction as extending from 1761 to 1820 . During that period the canal companies prospered, and the shareholders made large fortunes, but "the railway era opened almost contemporaneously with the close of canal construction, and the decadence of canals as a means of transport followed rapidly." 


\section{CHAPTER III}

Wool-Cotton-Calico-Printing, Dyeing, etc.-Linen-SilkHemp, Rope-making, etc.

Wool.

THE most important and the most ancient of British manufactures was the woollen industry. The importance of the wool trade-for centuries the staple industry of England-is shown by the long list of parliamentary enactments by which it was sought to encourage and protect the manufacture, to regulate the export of the finished goods, and to prevent the export of the raw material. In Roman times, British wool had a high reputation, and that this was continued till after the special period with which we are concerned, is shown by a story told by Bischoff, in his History of the Woollen Manufacture. During the American War, France granted a sum of money to Congress for clothing the American troops, and the agent employed was naturally blamed by the French Minister for having spent all the money in the purchase of English cloth. $\mathrm{He}$, however, justified his action by the argument 
that the English cloth was far superior to French material of the same price.

Thorold Rogers ${ }^{1}$ puts forward as one reason for the abundance of wool in the south of England (he does not suggest that there was any consequent improvement in quality) in the thirteenth century and later, the absence of the bands of marauders who ravaged Continental Europe at the time. He might perhaps have added that the Highland freebooters of a later date, who took toll of their neighbours' herds, usually considered it unworthy of their profession to carry off sheep.

In 1738, to judge from the returns of goods exported, "woollen manufactures in England had never been so prosperous, and were long before they again reached so high a pitch of activity." 2 But the manufacture was a domestic one, carried out mainly in the abodes of the farmers who raised the sheep. The growth and manufacture of the wool was to a very large extent, and in most parts of the country, in the same hands. The sheep were shorn, their fleeces carded, the thread spun, the cloth woven, all by hand, and by the farmer, his family, and his labourers.

Weaving, indeed, was becoming to a certain extent and in certain districts a special trade; but it was carried on for the most part by people

1 Six Centuries of Work and Wages, p. 51.

2 Wool and Woollen Manufactures, Samuel Brothers, 1859. 
who did not depend upon it for the whole of their livelihood. Even in districts in which the manufacture was becoming localised, the weavers were also agriculturalists, and supplemented their earnings by working in the fields. Elsewhere they were farmers who worked at the loom as a by-employment. ${ }^{1}$

Radcliffe $^{2}$ gives a description of the Lancashire village of Mellor in 1770, which would doubtless apply to many other villages at, and before, that date. Of fifty or sixty farmers, not more than six or seven raised their rent directly from the land, "all the rest got their rent partly from some branch of trade, such as spinning or weaving wool, linen, or cotton. The father of a family would earn from eight shillings to half-aguinea at his loom, and his sons, if he had one, two, or three alongside of him, six or eight shillings per week. But the great sheet-anchor of all cottages and small farms was the labour attached to the hand-wheel; and when it is considered that it required six or eight hands to prepare and spin yarn sufficient for the consumption of one weaver, this shows clearly the

1 Those who desire to study in greater detail the origins of the factory system in the later years of the century, with all the economic and social changes involved, cannot do better than consult Prof. Cunningham's admirable account of it, in his English 'Industry and Commerce, p. 494, to the end of his first volume.

${ }^{2}$ Origin of Power Weaving (1828), pp. 59 et seq. 
inexhaustible source there was for every person from the age of seven to eighty years of age (who retained their sight and could move their hands) to earn their bread, say one to three shillings a week, without going to the parish."

Everywhere the weavers were entirely dependent on the domestic spinners, who had no more efficient apparatus than the ancient spinningwheel, and in some districts used the still more ancient spindle and distaff.

For even in those places where weaving was carried on as an industry, it was still a domestic industry. The weaver worked at home, using yarn which had been collected from the farmhouses and cottages, where it was spun in single threads by the women on spinning-wheels of immemorial fashion. The chapmen, who collected and distributed the yarn, collected also the woven cloth, and carried it to the "mills," where it underwent the process of "fulling," that is to say, it was beaten by hammers or "stocks," so as to condense the fabric, and to felt together the fibres of the wool.

These mills offer one of the few instances of the use of mechanical power for industrial purposes, since they were driven by water-wheels, the stocks being lifted by tappets on an axle revolved by the wheel, and allowed to fall by their own weight, like the stamps now used for crushing ore. 
It seems probable that the principal seat of the woollen manufacture was, at one time, in the eastern counties-Norfolk and Suffolk-but it gradually migrated to the west, where indeed it had always been important, and by the time with which we are dealing, the centre of the industry was in the west of England. To a certain extent, different sorts of cloth were made in different places. Defoe tells us that the serge manufacture in Devonshire was very important, and this continued to be the case till the early part of the nineteenth century. In 1732, according to a writer in the Gentlemen's Magazine, Worcester subsisted on its woollen manufacture, and was "famous for making some of the best broad-cloth in England." Other important centres were Bradford - on - Avon, Stroud, Coventry, and Banbury. Leeds, Bradford, and Wakefield, in Yorkshire, had from an early date large woollen manufactures, which were in a flourishing condition throughout the eighteenth century. Later on, with the advent of the power loom, the industry settled almost entirely in the North of England, attracted, like the other industries, to the neighbourhood of the coal-fields.

In Scotland, Glasgow, Aberdeen, and Dundee had been the chief seats of the woollen industry, but after the union in 1707 the Scotch weavers could not compete with their English rivals, and they turned their attention to other fabrics. 
The manufacture, however, of Scotch plaids continued to be carried on successfully at Glasgow and elsewhere.

Dr Cunningham remarks that the history of the woollen trade in England is difficult to follow; we are, however, fortunate in possessing a complete account of the state of the manufacture here at the middle of the century, in a poem, "The Fleece," by John Dyer, published in 1757. ${ }^{1}$ The first and second books of the poem are devoted to the sheep :-

"The food of wool

Is grass or herbage soft, that ever blooms

In temperate air, in the delicious Downs Of Albion."

The shearer and the sorter are next referred to, and the measures taken by Government to prevent the exportation of wool by the smuggler ${ }^{2}$ who tries

"To waft his thefts to the perfidious foe."

1 Bischoff, in his History of the Woollen Manufacture, 1842, p. 164 , gives further extracts from the poem.

Johnson, though he devotes a chapter to Dyer in his Lives of the Poets, did not consider him "a poet of bulk or dignity sufficient to require an elaborate notice." "The Fleece," he says, "never became popular, and is now generally neglected." This he attributes to " the meanness naturally adhering, and the irreverence habitually annexed, to trade and manufactures." Johnson, however, quotes from Akenside an opinion commendatory of Dyer and his poem.

${ }^{2}$ Despite the many penalties (at one time seven years' transportation) against smuggling wool, there was an organised 
In the third book we find the process of manufacture described. The poet invokes the spinners :-

"Come village nymphs, ye matrons and ye maids Receive the soft material,"

"Whether ye turn around the spacious wheel,"

or

"The more ancient distaff."

The poet then deprecates the wrath of the nymphs, who object to machine spinning by the "spiral engine," 1

"Which on an hundred spoles, an hundred threads With one huge wheel, by lapse of water, twines,"

since there will always be demand enough for the work of the hand, as well as for that of the machine. Then we proceed to the weavers;

"What need we name the several kinds of loom?"

Their work is described with real accuracy, and in sufficiently smooth verse, until-

"From the blackened beam, the woof unrolled Near some clear sliding river, Aire or Stroud, Is by the noisy fulling mill received, Where tumbling waters turn enormous wheels, Where hammers, rising and descending, learn To imitate the industry of men."

business in it. A great deal of wool was "run" to France and Holland. Sometimes the wool smugglers brought over a cargo of spirits, so as to make a double profit.

1 Wyatt and Paul's roller-spinning apparatus mentioned below. 
Finally, the web is washed, hung up to dry

"On rugged tenters, to the fervid sun,"

until at last

"The clothier's shears

And burler's thistle skims the surface skeen."

On the whole, a very lucid and graphic description, which brings before us in a singularly clear fashion, and in by no means despicable verse, the exact condition of the industry at the time.

Blankets were made at a very early date at Witney, and perhaps at an even earlier date at Bristol, if Thomas Blanket (1320) really gave a name to the material of which blankets were made. In $\mathbf{1 7 1 0}$ the blanket weavers of Witney obtained a charter, but nevertheless " the industry flourished, in spite of the company rather than because of it." 1

But, besides being woven into cloth and blankets, wool provided work for a great army of knitters all over the country. Insomuch as the work was more generally distributed, knitting must have been as useful a supplement to the earnings of the small farmer and labourer as was

1 Victoria County Histories (Oxford), vol, ii., p. 247. Much useful information about local industries is contained in this valuable work. Some of the articles are much better than others, and the best of them are excellent. Unfortunately the work is not complete. It is to be hoped that it will not be allowed to remain in an unfinished condition. 
weaving. Doubtless the women all knitted, and the children, boys as well as girls, were taught to knit. Stockings and caps were the principal articles made. The industry, for such it really was, continued long after the invention of the stocking-loom, or frame, by James Lee in $1589 .{ }^{1}$ Framework knitting soon established itself in the country, but the stocking-frame never seems to have made its way into every part of the country, or to have taken up quite the same domestic position as the more ancient loom. Its use was rather concentrated at industrial centres. First, London seems to have been the chief seat of the trade, then Nottingham. The trade was also largely carried on in Derby and Leicester, and it seems by the middle of the century to have drifted away from the metropolis. The loom itself remained much as it left the hands of Lee. Very little improved, except in details, it remained an interesting example of an admirable mechanical invention in a non-mechanical age. The first important improvement was the addition by Jedidiah Strutt, in 1758, of an apparatus by which stockings could be knitted with ribs. Previously only plain goods could be made on the frame, ribbed stockings and other elaborate work having still to be made by hand. Strutt's works were set up in Derby, and therefore the

${ }^{1}$ Felkin, History of the Machine-wrought Hosiery and Lace Manufacture (1867). 
new sorts of stockings were known as "Derby ribs."

Lee's first frame was made for wool, but he himself adapted it for weaving silk stockings. Later on (1730) it was applied to cotton. Besides stockings and caps, other goods were made on the frame. Eventually Lee's simple apparatus developed into the elaborate and complicated lace-making machines of the present day.

In 1657 a Company of Framework Knitters had been incorporated by Oliver Cromwell, and the control of the whole of the business placed in their hands. From the beginning, however, the company was unpopular in London, and still more so in the provinces. The time was past for the mediæval control of an industry by a Gild. In 1728 an attempt of the company to control the Nottingham stocking weavers failed, and in $\mathbf{1 7 5 3}$ their authority over the trade broke down altogether. The company had also been unfortunate in its commercial speculations, for after accumulating a sum of $£ 10,000$ by fines and fees, it started manufacturing on its own account, and lost the money.

The work of the stocking-loom weavers seems to have been poorly paid ; it was easy, and required no great skill. The manufacture of the better class of goods seems to have fallen off, and by 1750, the English silk goods had become 
very inferior to those made in France. This led, in 1754 , to the prohibition of imports from that country.

At Kilmarnock, in Ayrshire, the knitting of Scotch "bonnets" or caps is a very ancient industry. It was an important business in the middle of the fifteenth century at Stewarton (Ayrshire) and Kilmarnock, and it is an important one at the present date. Before the introduction of knitting machines the caps were all knitted by hand. They were (and are now) "milled" or treated in a fulling mill until the wool is partly felted together, and afterwards finished off. ${ }^{1}$

\section{Cotton.}

It is said that when cotton was first brought into England it was only used for making candlewicks; but as far back as the middle of the sixteenth century, the manufacture of fabrics in which cotton was used had been introduced into Lancashire by exiles driven from the Netherlands by the persecution of Alva. These fabrics, known generally as "fustians," were composed of linen warp and cotton weft. They were of a coarse and heavy character, the finer calicoes and muslins being imported from India.

${ }^{1}$ Manufactures of the West of Scotland (British Association Handbook, 1876), p. 207. 
The system under which these fustians were manufactured in 1750, is described as follows :

"The master gave out a warp and raw cotton to the weavers, and received them back in cloth, paying the weaver for the weaving and spinning; the weaver, if the spinning was not done by his own family, paid the spinners for the spinning, and the spinners paid the carders and rovers."

For the protection of the woollen industry, various Acts of Parliament were passed prohibiting the use of cotton materials; but in $1736^{2}$ the manufacture of the mixed material was authorised, provided always that the warp was of linen yarn. The skill of English spinners was insufficient to enable them to produce the fine yarns used in Eastern looms, and apparently they were unable to spin cotton yarn of sufficient strength for the warp threads. "Up to the year 1760 the machines used in the cotton manufacture in England were nearly as simple as those of India," ${ }^{3}$ from which country indeed all the calicoes and muslins were imported. The Indian fabrics were beautiful and cheap, so naturally they became popular. Defoe, in 1708, complained that the English woollen manufacture

${ }^{1}$ Guest, Compendious History of the Cotton Manufacture (1823), p. 10.

${ }^{2}$ Lecky (First Edit.), vol. vi., p. 207. Baines, History of the Cotton Manufacture (1835), pp. 166-7, etc.

3 Baines, p. 115. 
was being ruined by the East India trade in calicoes and silks, and the same idea of protecting the wool industry led to many Acts of Parliament prohibiting or hampering the manufacture or importation of fabrics of other materials. It was "penal for any woman to wear a dress made of Indian calico. In 1766 a lady was fined $£ 200$ at the Guild Hall because it was proved that her handkerchief was a French cambric. In the same year an attorney named Brecknock... avenged himself upon Lord Camden by laying an information before Judge Fielding, ${ }^{1}$ that the Chief Justice and three other Judges wore cambric bands in court, contrary to the Act of Parliament." 2

In this desire to protect the wool industry may doubtless be found the cause of England being among the last countries to adopt the manufacture of cotton; and when it was taken up, the workers in cotton had to face the same difficulties as their rivals of the older established industry. The weavers had to depend upon the hand-spinners. Their output was necessarily limited, and when the fly-shuttle of $\mathrm{Kay}^{3}$ in 1733

1 Perhaps this was really Sir John Fielding, Henry's brother. There does not appear to have been any contemporary judge of this name.

2 Lecky, vol. vi., p. 235.

3 Before Kay's invention the weaver had to use both hands, throwing his shuttle from one, and catching it in the other alternately, or in fabrics which were too wide for the arms of one 
doubled the speed of the loom, the spinners found it still more difficult to keep up with the demand of the weavers.

The cotton industry suffered in this respect more than that of wool. It was more recently established, more concentrated in certain localities, and its raw material was imported, instead of being home-grown. There were wool spinners in every village in the country, but it was only in comparatively few localities that cotton was spun at all. Hence a need which could only be supplied by machinery, was more insistent in the cotton than in the wool trade, though when machinery was once introduced, its effect was felt in all the textile industries alike, and its introduction affected them all to an almost equal extent.

Machines for throwing and twisting silk had

man to stretch across (broad-cloths), two men had to be employed, one on each side. In Kay's device the shuttle is thrown and caught by a "picker" on each side, and the "pickers" are worked by a cord from each, passing to a short lever held in the weaver's right hand. He is thus able to jerk the shuttle to and fro by the movement of one hand, while the other is left free to drive home the weft by the movement of the "layer." A full description of Kay's inventions is given in Woodcroft's Brief Biographies, and a good popular account (largely adapted from Woodcroft) in Espinasse's Lancashire Worthies. Kay's shuttle and his other improvements in looms were originally intended to be applied to the weaving of woollen fabrics, whereas most of the other and later improvements in textile machinery were devised for use in spinning and weaving cotton, though afterwards adapted for other materials. 
for long been used in Piedmont and Italy. As mentioned later on, they were successfully introduced into England in 1718. With that exception, the first attempt to apply machinery to the production of spun thread in this country ${ }^{1}$ was that of Wyatt and Paul, who in 1738 obtained a patent for a machine for "spinning by rollers." 2

That this remarkable invention was capable of producing excellent work is proved by abundant evidence, but it was in advance of its time, and was never properly developed. Baines records the production of a hank of yarn "spun by the spinning engine (without hands) about the year 1741." "The movement was . . . turned by two asses . . . walking round an axis." How many million horse-power are now employed on precisely the same work as those "two asses" of a hundred and seventy years ago, it might be

1 Bennet Woodcroft, Brief Biographies of Inventors of Machines for the Manufacture of Textile Fabrics, 1863.

2 There has been much argument about the relative claims of Wyatt and Paul, and the question is never likely to be settled, since Wyatt's papers were burnt in a fire in Birmingham in 1879. The patent was granted to Paul alone, Wyatt's name appearing as a witness. The hanks of cotton referred to (there are two) are still preserved in the Birmingham Museum. The last word of the controversy is probably to be found in a pamphlet published anonymously in 1885 under the title of John Wyatt, Master Carpenter and Inventor. It was written by the Birmingham agent of Messrs Pooley, the weighing-machine makers. Wyatt was certainly the inventor of the platform weighing-machine. He was associated with Matthew Boulton in the Soho works, and died in 1766. 
troublesome to calculate. Some of Wyatt's machines, driven by water-wheels, were also set up in Birmingham and in Northampton, but we hear nothing more of their products.

The weavers had to wait for another twentyfive years before they could be supplied with machine-made yarn from the apparatus which Hargreaves invented in 1764, and called "Jenny," after his wife. In this a number of spindles were combined-the first jenny had eight-and the production of yarn correspondingly increased. A few years later, in 1769, Arkwright patented his "water - frame" (so called because it was driven by a water-wheel), in which the method of spinning by rollers proposed thirty years before by Wyatt and Paul was employed. In his "throstle" Arkwright spun a hard firm thread, suitable for the warp, and the linen warp was thereafter discarded. Finally, about 1780, Crompton combined in his "mule" the two principles of Arkwright's frame and Hargreaves' jenny, and produced the machine which, after many improvements, still supplies all the yarn employed in the textile manufactures of this and every other country.

The improvements in spinning machinery which provided for the supply of any required amount of yarn, rendered possible the introduction of the power-loom by Cartwright in $\mathbf{1 7 8 5}$. Hardly had this been set to work when the 
steam-engine was ready to drive it, and by 1790 it was applied to the purpose.

As reference was made to the poet of the wool manufacture, it is only fair to say that cotton also had its sacer vates, though at a little later day, in the person of Erasmus Darwin, who in his Botanic Garden (published in 1792) describes in ponderous verse Arkwright's factory on the Derwent.

As the cotton manufacture, unlike that of wool, was not concerned with a domestic product, it was carried out under different conditions, and was from the first concentrated in localities. Manchester, from its proximity to Liverpool, was favourably situated for obtaining the raw material, and was from the first the principal seat of the manufacture. Cunningham thinks that from the very first the weavers there were wage-earners, though they worked at home, and probably in most cases owned their own looms. It seems most likely that they received the raw material from the employers, who paid them on delivery of the woven cloth. This was certainly the system adopted in Manchester a little later, during the period of expansion, when machine spinning was coming into use, and the number of looms increased so rapidly that it was difficult to find shops for them. ${ }^{1}$

${ }^{1}$ Cunningham, p. 627. Quotations from Radcliffe's New System of Manufacture. 
It was not until later in the century that cotton weaving was introduced into Scotland. When it was established there the most important products were fabrics of the finer sort, muslins and the like. Eventually Paisley obtained a reputation for wares of this kind, and this led to a considerable domestic industry in the handembroidery of muslins, which prospered for a long time in Western Scotland. ${ }^{1}$

\section{Calico-Printing, Dyeing, etc.}

Amongst the early exports from India and the East were dyed and printed calicoes and muslins. $^{2} \quad$ The dyeing was effected by methods of immemorial age. The printing was done by means of blocks pressed by hand on the fabric, or in some cases the fabric was painted by hand. It is said that calico-printing was commenced in London in 1676. ${ }^{3} \quad$ Another authority gives 1690 as the date, and Richmond (Surrey) as the precise locality. In 1700 the importation of printed calicoes from the East was prohibited by an Act of Parliament, and as the Eastern wares were fashionable, this encouraged the printing in England of plain Indian calicoes, still admitted under a duty, and also of linen and silk. This business was carried on almost exclusively in the

1 Manufactures of the West of Scotland (1876), p. 195.

${ }^{2}$ It is said that Queen Mary (the wife of William III.) had a great love for these coloured calicoes.

${ }^{3}$ Anderson's History of Commerce, quoted by Baines. 
neighbourhood of London till the middle of the century, when it gradually migrated to Lancashire. Messrs Clayton are said to have started the business on a small scale at Preston in 1764. A little later it was taken up and vigorously developed by Robert Peel, the grandfather of the statesman. The work was executed in the ancient Eastern fashion by wooden engraved blocks, about ten inches by five; later copper plates were used, and about 1785 came the great invention of cylinder printing.

Glasgow, however, may have anticipated Lancashire in the introduction of textile printing, if it is true that "calico printing was an industry in the neighbourhood of Glasgow as early as 1738." ' Perhaps, however, the introduction of calico-printing into Scotland ought to be dated a few years later. A Glasgow historian ${ }^{2}$ mentions an advertisement in the Glasgow Journal of 1756, to the effect that "printed cottons of the newest patterns lately imported from London" could be had at Mr Stirling's warehouse "above the Cross." In the same journal in $\mathbf{1 7 6 4}$ William Stirling and Co. were advertising that they would print linen and cotton cloth for their customers, as they had engaged "a man of character in the printing business

${ }^{1}$ Local Industries of Glasgow and the West of Scotland (British Association Handbook, 1901), p. 141.

2 The Editor of Old Country Houses of the Old Glasgow Gentry, Second Edition, 1878, p. 86. 
lately in London." The customers could select their own patterns from pattern books kept by the firm's agents in Edinburgh, Greenock, Ayr, Paisley, and elsewhere.

The methods of dyeing, to whatever textile material they were applied, had certainly made no great progress by the time with which we are dealing. The advances which have since been made are due to chemical knowledge, which did not at the time exist, even in the most elementary form. The dyer of the eighteenth century, like his fellow-craftsmen of the earlier centuries, worked by simple rule-of-thumb. All his knowledge was empirical and traditional. He really knew nothing whatever of the principles of the processes he employed. His materials also were limited. Bishop Sprat, in his History of the Royal Society (published in 1667), prints a communication from Sir William Petty, on the History of Dyeing, which gives a full list of tinctorial agents. The writer of the article on the subject in Chambers' Cyclopadia ${ }^{1}$ in 1751,

1 The first edition of Chambers' Cyclopoedia was published in 1727. The edition in the Royal Society of Arts Library to which references are made in this work is the seventh, published Vol. I. in 1751 and Vol. II. in 1752. The book is full of curious and interesting information, but the later editions (issued after Chambers' death in 1740) do not appear to have been brought up to date. The Cyclopadia may certainly be taken as affording incontrovertible evidence of the existence of any process or invention it describes, but it cannot be relied upon as a record of full contemporary knowledge. An interesting point about 
copies Petty's list, so probably it is a fair assumption that the list of dyeing materials had not been greatly extended in the interval. The actual dyes are nearly all vegetable. The principal are Logwood, Fustic (from the Maclura tinctoria); Brazil - wood (Cosalpinia brasiliensis); Madder, Woad, "Indico" "made of a weed of the same nature with woad;" Woodwax (Genista tinctoria, or greenweed); Weld (Reseda lupeola, or dyer's mignonette) and Arnotto. Cochineal was another important dye. The mineral ingredients include arsenic, verdigris, and copperas (ferrous sulphate), ${ }^{1}$ which was used with oak galls for making a black dye. ${ }^{2}$ Prussian blue (made by mixing solutions of potassium ferrocyanide and ferric sulphate) is not mentioned, though it was known, and was being manufactured at Elswick in the middle of the eighteenth century. ${ }^{3}$ Then there were what were really mordants, though the principle of their action was unknown. Chief of them was

Chambers is that it was really the origin of the great French Encyclopédie, which was started as a translation of the English work. So, at least, says the exhaustive article on Encyclopædias in the Encyclopoedia Britannica.

1 The use of smalt (silicate of cobalt), for "blueing" linen is referred to in Chambers' Cyclopoedia (1751), but it is not included in the list of dyes. It was imported, the manufacture not having been started in England till later.

2 This is, of course, ordinary ink.

3 Industrial Resources of the Tyne, Wear, and T'ees, Second Edition, 1864, p. 172. 
alum (Petty is puzzled as to the object of using alum), but "aquafortis impregnated with pewter," which would seem to provide a solution of impure lead and tin nitrates, is also mentioned, and so are saltpetre and argol (bitartrate of potash). ${ }^{1}$

\section{LINEN.}

The manufacture of linen was not, at all events to any great extent, carried on in England, though linen warp was used for cotton goods until the introduction of the spinning-jenny and the frame enabled cotton warp of sufficient strength and fineness to be produced. The chief seats of the industry were in Scotland and Ireland.

In the west of Scotland the linen industry was well established before the Treaty of Union in 1707.

" The cultivation of small patches of 'lint' and the preparation of the fibre until it was ready for' spinning was a recognised part of farmwork. It was pulled, rippled, steeped, butted, scutched, and heckled by the farmer, who turned it over to be home-spun and bleached by his women-folk. On the long winter nights the women round the ingle spun their tint of tow. The yarn so spun was turned over to the merchants of Glasgow

1 The French Encyclopédie (Article "Teinture," edition of 1765) gives a full and detailed account of the methods and materials then used. The list of dyes is longer than that in Chambers, but the additions do not seem very important. 
and of Paisley, who distributed it to the weavers of the towns and villages and hamlets of the country around." I

The Union of 1707 gave a great impulse to the Scotch textile manufacture. If wool could no longer be exported it could be sent into England, and England was also opened up to the linen trade. Larger amounts of linen were sent over the border, and in return there was a greater importation of English woollen goods. The English colonies and plantations abroad also provided a lucrative market for Scotch linens, in return for which colonial produce was brought to Glasgow. ${ }^{2}$

The Scotch manufacturers are said to have been slow to adopt any improvements in their apparatus, though the fly-shuttle was introduced into Paisley not long after its invention. Still the industry prospered in Glasgow, Paisley, and the surrounding district until the latter part of the eighteenth century. Owing to various causes, of which the introduction of machinery was the chief though not the only one, it then migrated from Glasgow to the East of Scotland, though Paisley remained, and still remains, a great textile centre.

In the early part of the century the manu-

1 Local Industries of Glasgow, etc. (1901), p. 137.

${ }^{2}$ Manufactures of the West of Scotland (1876), p. 186. 
facture of fine linens, lawns, and cambrics formed the staple industry of Glasgow; and this developed, until

"About the year 1780, just when the cotton weaving was beginning to supplant linen, there were in the Barony parish of Glasgow alone, nearly 3000 looms engaged on linen fabrics, lawns, cambrics, diapers, checks, handkerchiefs for printing, and 'blunks'-a fabric with linen warp and cotton weft used for neck-ties, gowns, and bed-curtains." 1

On the east coast Aberdeen and Dundee had, by the middle of the eighteenth century, become known as important centres of the linen trade, which, especially in the latter town, afterwards developed to a very large extent. But this was after the introduction of textile machinery.

The manufacture of sewing thread was established in West Scotland about the end of the seventeenth century by Christian Shaw, ${ }^{2}$ the daughter of John Shaw of Bargarran in Renfrewshire. She was herself a very skilful spinner of fine linen yarn, and, assisted by a relative who obtained information from Holland as to certain secret methods of thread-making, she set up

1 Manufactures of the West of Scotland (1876), p. 200.

${ }^{2}$ A tragic history is associated with the name of Christian Shaw. In 1697 seven persons were executed in Paisley for having bewitched her. The story is summarised in the British Association Handbook for 1876 above referred to, and is told at full length in The Witches of Renfrewshire. 
mills in which such excellent thread was produced that it soon obtained a more than local reputation, and was exported to England for purposes of lace-making. It was known first as "Bargarran" and afterwards as "ounce" or "nun's" thread.

The industry thus started became one of great importance, and has continued to the present day, Paisley being now the chief seat of the thread manufacture. Originally confined to linen thread, it extended, when cotton was introduced, to the production of cotton thread also, and the latter material gradually superseded the former. Even now, however, large amounts of linen thread are made in Paisley and in Glasgow.

In Ireland the manufacture of linen was encouraged by the English Government, partly at all events from a desire to prevent the Irish wool industry from developing into a rival to the wool trade of England.

It is said that the first mention of Irish linen occurs as far back as the thirteenth century, but the linen trade of Ulster really dates from the Revocation of the Edict of Nantes in 1685, some of the Huguenot refugees having settled in Lisburn. Later Belfast became, as it has since remained, the headquarters of the industry.

The conditions under which it was carried on were similar to those prevailing in the manu- 
facture of woollen cloth. "The hand-loom weavers purchased the necessary yarn, wove it at home into cloth, and brought the work to market, where it was purchased by the merchants and bleachers or their agents." 1

The bleaching alike of linen and cotton fabrics was carried out by exposure to air and light, together with frequent steeping in sour milk or other weakly acidified liquid. As conducted in the middle of the eighteenth century, it took from six to eight months. Nearly all the linens made in Scotland were sent to Holland to be bleached. A little later Home of Edinburgh, by the use of a weak sulphuric acid solution, reduced the time by half, and in $\mathbf{1 7 8 5}$ the great French chemist Berthollet utilised for bleaching purposes Scheele's discovery of chlorine in $\mathbf{1 7 7 4 .}$

An important "by-industry" connected with linen, was lace-making. Established in England at a very early period, it had developed from a rough peasant industry, till, by the eighteenth century, its wares were competing with-though they never quite equalled-the more artistic and more beautiful work turned out by the older factories of Flanders and France. Those who desire full information about the history of English lace, can study that history in Mrs Bury Palliser's well-known book. ${ }^{2}$ It will be sufficient

${ }^{1}$ British Manufacturing Industries: Linen, by W. T. Charley (1877).

${ }^{2}$ History of Lace, Mrs Bury Palliser, 1861. 
to summarise here the information she gives about the condition of the art at the time with which we are concerned.

This may, perhaps, be best done by the quotation of a single paragraph :- "From Cambridge to the adjacent counties of Northampton and Hertfordshire, by Buckinghamshire, Bedfordshire, and Oxfordshire, the trade spread over the southern counties of Wiltshire, Somersetshire, Hampshire, and Dorset, to the more secluded valleys of Devon-the county which still sustains the ancient reputation of "English point" till it reached Launceston, in Cornwall. Lace was also being made in London, in Wales, at Ripon, and elsewhere. Nearly all was pillow or bone lace, so called because fish-bones were used for pins, when pins were scarce and dear. The manufacture was at its best in the latter part of the eighteenth century, till machinery came in to destroy it and all the other domestic handicrafts which had for years played so important a part in the country life of England, and had added so much to the comfort and welfare of the country-folk.

Thread for the best lace was imported from Antwerp, Hamburg, and elsewhere, but English thread was used for the coarser sorts. The lace was principally made by women and children, but men also worked at it.

The import of foreign lace was for the most 
part prohibited, but large quantities were smuggled. Mrs Palliser devotes a chapter of her book to an account of the smuggling which went on, especially after 1751, when the prohibition was stringently enforced, and detected foreign lace was liable to be seized and burnt.

\section{Silk.}

As far back as 1585 the silk manufacture was started in this country by Flemish weavers, driven out of Flanders by Spanish persecution; and again, in 1685, the Revocation of the Edict of Nantes caused the settlement, first in Canterbury and then in Spitalfields, of a number of French weavers. ${ }^{1}$ Silk weaving, in London and elsewhere, became a large business. It was protected by high duties, and sometimes by prohibition of import. "The industry has always been fostered by Government, though it is doubtful if it would not have been much more vigorous and successful if left to itself." 2

For "throwing" silk, mechanical power seems to have been used from an early date in Italy and Savoy, and if, in this respect, the silk

1 Those who care to study in greater detail the interesting question of the introduction into England by foreign immigrants of new industries and improved methods of manufacture, may be referred to Archdeacon Cunningham's Alien Emigrants to England.

${ }^{2}$ British Manufacturing Industries: Silk, by B. F. Cobb (1877). 
manufacture was in advance of the other textile industries, it was, perhaps, because the long silk fibre was more easily twisted into a thread than the short fibres of wool and cotton. In 1718, Sir Thomas Lombe introduced machines into England from Savoy, and in the same year a patent was granted to him for "a new invention of three sorts of engines never before made or used in Great Britaine, one to winde the finest raw silk, another to spin, and the other to twist the finest Italian raw silk into organzine ${ }^{1}$ in great perfection, which was never before done in this country." Several descriptions of the machinery are extant. The best is probably the one in Rees' Cyclopoedia; but as this was published in 1819 , it is not quite certain that the apparatus there described is identical with that for which the patent was granted. ${ }^{2}$ The various parts of the machinery all derived their movements through gearing from a main shaft driven by a waterwheel. $^{3}$ It is said that the jealously-guarded secret was only discovered by Lombe's brother

1 Thread suitable for warp, made by twisting together two or more of the finer threads into which the filaments are first spun.

${ }^{2}$ A specification was duly filed, but the description is not easy to follow.

${ }^{3}$ Some remains of the models deposited by Sir T. Lombe in the Tower of London, in 1741, are preserved in the Mechanical Engineering Collection at South Kensington. The purpose and object of these fragments is made clear by a drawing. (See Catalogue, part 2, p. 143.) 
John, who was sent over to Italy for the purpose. The story goes that John Lombe was eventually poisoned by an agent sent to England by the Italians, but this romantic history is rather doubtful.

Lombe set up a mill at Derby in 1719, with workmen brought over from Italy. It was very successful, and the works have been continued down to the present day. When the patent expired in 1732, Lombe petitioned for an extension. The petition was refused, but a reward of $£ 14,000$ was given to the inventor, who does not, on the whole, seem to have done so badly out of his invention, since, when he died, in 1739, he left a fortune of $£ 120,000$. He was an Alderman and Sheriff of the City of London, and was knighted in 1727. An excellent account of Lombe's life and doings is given in the Dictionary of National Biography. ${ }^{1}$

One specially interesting point about Lombe's petition is that it was the first after the Statute of Monopolies for the extension of a patent beyond the term of fourteen years. ${ }^{2}$

Silk-throwing machinery was set up at Sher-

${ }^{1}$ The author of this article is Mr R. B. Prosser. It is an admirable summary of an interesting bit of the history of invention, to which hardly sufficient attention has been directed by writers on textile machinery.

${ }^{2}$ References are made to his invention by Baines and Cunningham, and Smiles devotes a chapter of his Men of Invention to him. Other authorities are quoted by Mr Prosser at the end of his article. 
borne, Dorset, in $1740,{ }^{1}$ in Gloucestershire, and doubtless elsewhere. It was probably one of these machines that was erected in the "silk mill" at Macclesfield which Brindley, then an apprentice, repaired in 1785 . This was the first piece of mill-work undertaken by that great engineer. ${ }^{2}$

It is believed that some of the expatriated weavers from Tours and Lyons settled in Coventry and started ribbon-making there, but the early history of the trade there is obscure. Up to $\mathbf{1 7 7 0}$ single hand-looms, making only one ribbon, were used. The weavers, who were called "undertakers," received the dyed silk from the dealer, provided their own looms and labour, and received a stipulated price from the dealer when the finished goods were delivered. ${ }^{3}$

The manufacture of silk gauze was started at Paisley, where much fine weaving was then carried on, in 1760, and in 1772 ribbon weaving was added to the silk industries of the district, where they had by that date attained a very prosperous condition. ${ }^{4}$

The manufacture of poplin, a mixed fabric of

1 Victoria County Histories (Dorset), vol. ii., p. 362.

${ }^{2}$ Smiles, Lives of the Engineers, vol. i., p. 314.

${ }^{3}$ Timmins, Birmingham and the Midland Hardware District, 1866. This excellent account of Birmingham industries was prepared in connection with the meeting of the British Association in 1866.

${ }^{4}$ Manufactures of the West of Scotland (1876), p. 211. 
silk warp and worsted weft, is said to have been established in Dublin about 1693 by Huguenot refugees, and to have been continued on a successful basis ever since. ${ }^{1}$

Before the American War of Independence bounties were offered for the growth of silk in the British Colonies, and Franklin was interested in the subject, but the attempts to produce colonial silk were not very successful.

\section{Hemp : Rope-making.}

The manufacture of rope was doubtless carried on from the earliest times at all shipping towns, and indeed all over the country. Quite at the end of the century rope-making machinery was introduced, but before that time all rope was made, as some is still made, by hand in the ancient "rope-walk."

A great deal of hemp was grown in various parts of the country, but much was also imported from the Baltic.

The commerce between the Russian ports and Newcastle led to the early establishment of rope-making factories in that town and its neighbourhood, when ropes were required not only for shipping, but for use in the coal-mines. Some of the roperies were on the banks of the Tyne, so that the larger ship's cables which

${ }^{1}$ Note on the Textile Industrics of Dublin, in the British Association Handbook, 1878. 
"could not be coiled into lifting coils nor weighed" might be run direct "on end" into craft which conveyed them to the ships."

The manufacture of rope, cordage, and fishingnets had been the staple industry of Bridport, in Dorsetshire, from a very early date. The raw material was the hemp which was grown in large quantities in the county. By the middle of the eighteenth century the business had somewhat decayed, owing to the importation of hemp and hemp yarn from Holland and Russia, and also to the development of the manufacture elsewhere. The making of twine and of nets was, however, still flourishing, and indeed has continued to the present day, when it still offers one of the few surviving examples of a domestic industry. ${ }^{2}$

The making of sail-cloth is said to have been introduced into England about 1681 by Bonhomme, a French immigrant, ${ }^{3}$ but it was an established industry in Ipswich ${ }^{4}$ a hundred years before that date. In the middle of the seventeenth century Suffolk sail-cloth had a considerable reputation, and so had the cloth made in the West country at Bristol, Weymouth, and elsewhere. In both cases it was made

1 Industrial Resources of the Tyne, etc., p. 251.

2 Victoria County Histories (Dorset), vol. ii., p. 34.

3 Cunningham, Alien Emigrants in England, p. 239.

4 There is a very good account of the origin and development of the Suffolk sail-cloth industry in the Victoria County Histories (Suffolk), vol. ii., p. 271. 
originally from locally-grown hemp, of which large quantities were produced in Suffolk, as well as in Dorsetshire and Devonshire. Canvas, as its name implies (cannabis, hemp), was at first made solely from hemp. Later flax was used, but the linen canvas seems to have been considered inferior. There was the usual difficulty about yarn. The spinners could not supply sufficient for the demands of the weavers. By the middle of the eighteenth century this demand was no doubt partly met by imported yarn from Russia, though the cloth itself seems to have been brought from the same country, since in $\mathbf{1 7 4 5}$ there were complaints on this ground from the English makers in several localities. The industry was a flourishing one in the latter part of the eighteenth century, and continued in Suffolk into the nineteenth. To a small extent hemp was used for table linen and sheets, and even for shirts. 


\section{CHAPTER IV}

Iron-Copper and Brass-Lead-Pewter-Gold and SilverCoal-Quarries and Stone-mining

\section{IRON.}

THE manufacture of iron, which had been carried on in the Forest of Dean and in Sussex intermittently from Roman times, and later in Yorkshire, Shropshire, Durham, Worcestershire, and elsewhere, had declined by the middle of the eighteenth century. Smiles, in his account of the early English iron manufacture, tells us that in $\mathbf{1 7 4 0}$ there were only fifty-nine furnaces in all England, of which ten were in Sussex. ${ }^{1}$ This was due to the destruction of the woods, since charcoal was the only fuel by which iron could be made, and also to legislative restrictions forbidding the use of wood for the purpose. Abundance of wood was in early times a more important factor than a sufficient supply of iron ore, and it was often found more economical to convey the ore to the wood, shifting the wind-

1 "In 1740, Gloucester was the largest iron-producing county in England. Sussex had the greatest number of furnaces."Industrial Resources of the Tyne, etc., p. 18. 
furnace from one position to another as the trees were consumed. The bulk of the iron used in the country was imported from Sweden and Russia, four-fifths of it being brought from the former country. The total production of English iron at this time was said to have been about 18,000 tons a year. ${ }^{1}$

The last important production of the Sussex and Kent iron-works was the railing of St Paul's Cathedral, made early in the eighteenth century. ${ }^{2}$ The last furnace in Sussex is said to have been that at Ashburnham, which was blown out about 1811, but the manufacture was practically extinct twenty or thirty years before that.

The history of the origin and growth of the iron manufacture in England has been often

1 The present annual output of pig-iron is over $10,000,000$ tons.

2 According to the best authorities, these railings were cast at the "Gloucester Furnace" at Lamberhurst, a village on the borders of Kent and Sussex. At one time the village was partly in Kentand partly in Sussex, but since 1889 it has been wholly in Kent. Murray's Handbook for Sussex gives some particulars about the weight and cost of the railings, and adds that a furnace near Mayfield disputes the honour of having produced them. Furley's Weald of Kent also gives a full account of the Lamberhurst iron-works. There is now a farm, called "Furnace Farm," on the site of the old works. The railings (which were not designed by Wren) originally extended westward, enclosing the statue of Queen Anne, but they were removed from the West Front in 1874. Those which still remain, surrounding the rest of the churchyard, are the original railings. 
told. ${ }^{1}$ The first step in its progress was the substitution of coal for wood charcoal in the process of reducing the metal from its ores. In the iron-works of Sussex and elsewhere, the iron was made on open hearths or in small furnaces, by the help of bellows worked by hand or water. In ancient times the natural force of the wind was utilised, which, as an early writer ${ }^{2}$ says, "saveth the charge of the bellowes, and of a milne to make them blow."

The ingenious blowing apparatus forming part of the Catalan furnace-in which a blast was produced by the action of a falling stream of water-never seems to have been introduced into England, though it was well known on the Continent.

In such furnaces, with their moderate temperatures, uncoked coal could not be used, and the sulphur and other components of the coal affected the product injuriously. Nevertheless numerous efforts were made-more or less

${ }^{1}$ Dr Percy, at the end of his classical work on Iron and Steel, gives a "Sketch of the History of Iron," and several chapters of Dr Smiles' Industrial Biography are devoted to a graphic and more popular account of the same subject. Many other authorities might be quoted. Reference is made to some of them by Dr Percy.

${ }^{2}$ Rovenzon, to whom Sturtevant's patent was transferred, (1612) in his Treatise of Metallica. Rovenzon's treatise, and Sturtevant's work of the same name, were both republished by the Commissioners of Patents in 1858. The original date of Sturtevant's pamphlet was 1612 : that of Rovenzon's 1613. 
successfully - to use the cheaper and more abundant fuel, and but a very few years before the special date with which we are concerned, the new method may be said to have been placed on a commercial footing. ${ }^{1}$

It was at Coalbrookdale, ${ }^{2}$ in Shropshire, that Abraham Darby established the manufacture of iron by coal, about 1730 or 1735 . He treated the coal as the charcoal-burners treated wood, and found that in the resulting coke he had the fuel he required. ${ }^{3}$ In 1754 he had some seven furnaces (presumably small blast furnaces or reverberatory furnaces), and for blowing these he had five "fire engines" (steam or atmospheric engines), which pumped water to drive water-

${ }^{1}$ Simon Sturtevant obtained a patent from James I. in 1611 for the use of "Sea-coale or Pit-coale" in iron-making. His method was not published, but is believed to have consisted in coking the coal. Two years later, his privileges were transferred to Rovenzon, who describes a reverberatory furnace. After 1619 Dudley certainly succeeded in making iron with coal, and in 1665 he published his Metallum Martis, in which he gives an account of his work, without describing his method. As Charles II. refused to renew the patent granted to Dudley by Charles I., he abandoned his attempts, and nothing was done for another hundred years, when Abraham Darby at Coalbrookdale finally solved the problem.

${ }^{2}$ This is the usual spelling. Percy has Colebrook, and gives Coldbrook as the original name.

3 "A.D. 1763 appears to be the earliest period in which coke ovens are mentioned, and M. Jars, in a work published in 1774, gives a drawing of 'nine kilns at Newcastle for destroying the sulphur and reducing coal to cinders and coake.'"-Industrial Resources of the Tyne, etc., p. 19. 
wheels which worked the bellows, the "rotative" engine not having then been invented. Such was the point that the manufacture of iron had reached at the time about which we are concerned. A few years later, in or shortly after 1760, Dr Roebuck used blowing engines at the Carron Iron Works in Stirlingshire. These had four single-acting cylinders of cast-iron, 4 feet 6 inches in diameter, and the pistons, of which the stroke was 4 feet 6 inches, were worked in alternation, so that a continuous and tolerably equal blast was maintained. ${ }^{1}$ They were constructed by Smeaton.

It was the father of this Abraham Darby, Abraham the elder, who introduced into England, about 1706, the art of casting iron vessels. ${ }^{2}$ The story, old and well known as it is, will bear retelling. Early in the eighteenth century John Darby brought over some Dutch brass-founders, and set up a foundry in Bristol. Here he tried to make iron pots instead of brass, but failed, till his Welsh apprentice, John Thomas, "thought he saw how they had missed it," tried the experiment, and, working secretly with Abraham Darby (the son of John), cast the same night an iron pot. "For more than 100 years after the night in which Thomas and his master made

1 Percy, Iron and Steel, p. 889.

2 Dr Percy gives in full detail the history of the Darby family, and of their improvements in iron-making. 
their successful experiment of producing an iron casting in a mould of fine sand, with its two wooden frames and its air-holes, the same process was practised and kept secret at Colebrook Dale, with plugged keyholes and barred doors." 1

It is about this date (1740, or a little later), that Huntsman ${ }^{2}$ perfected the process of making cast-steel, which is still employed. Before this, "steel was never melted and cast after its production." "By whatever method prepared, whether by the addition of carbon to malleable iron, or by the partial decarbonisation of pig iron, . . steel in mass was never obtained homogeneous." 3 There is no need to describe the process, with its purely technical details. It may be sufficient to record the fact that the problem of producing ingots of steel of uniform composition was solved by Benjamin Huntsman, and that, as his secret method of working was stolen by a workman, it soon came to be generally employed in the Sheffield steel trade.

These early founders of the great British iron trade were soon followed by many others, chief of whom was Henry Cort, with his invention of puddling (1783), and of grooved rolls about the same time, and the manufacture, stimulated, in

1 Percy, Iron and Steel, p. 887.

2 The firm of Huntsman is still in existence. A Benjamin Huntsman died 27th January 1910.

${ }^{3}$ Percy, Iron and Steel, p. 878. 
the latter days of the century, to meet the rapidly growing demand for iron caused by the development of machinery and the steam-engine, soon reached a most important place among the industries of the country.

The manufacture of utensils and implements of iron was generally carried on wherever the articles were required, by the local blacksmiths. A certain amount of centralisation there doubtless was, even from an early date. The Sheffield whittle was known in Chaucer's days, and the town had an early reputation for various sorts of cutlery. The Cutlers' Company of Sheffield dates from 1621. Possibly the abundance of ironstone and the extensive woods (which, however, had all disappeared before the end of the seventeenth century) had something to do with this. Another cause which first made Sheffield an industrial centre was the amount of water-power from the numerous falls in the neighbourhood. ${ }^{1} \quad$ Yet another reason for the early prosperity of Sheffield, and of many other towns, was that it was not incorporated, and there were no trade gilds to restrict the practice of a special craft to their own members. Sheffield, Birmingham, Leeds, and many other thriving cities owe much of their first prosperity to this early form of free trade.

The manufacture of iron in America is said

${ }^{1}$ See Hunter's Hallamshire, p. 5. 
to have been started in 1715, in Virginia, and to have been carried on a little later in Maryland and Pennsylvania. ${ }^{1}$

The conditions for the production of iron were favourable, as there was abundance of wood and a sufficiency of iron ore. ${ }^{2}$

The proposal to allow the importation of American iron duty-free, gave rise to a good deal of acrimonious discussion in Parliament and outside it. It was naturally opposed by the English ironmakers, and supported by those who required iron. The conditions under which importation was permitted varied from time to time. An Act for encouraging it was passed in 1750, and the amount brought in, though never very considerable, was increasing until the war of 1775 cut off the supply.

\section{Copper and Brass.}

Without considerable research it might be difficult to give anything like a trustworthy account of the condition of metalliferous mining and metallurgy in the middle of the eighteenth century, and even if the labour were undertaken,

${ }^{1} \mathrm{H}$. Scrivenor, History of the Iron Trade (1854, Second Edition), p. 69.

2 The date of the first iron-making in Pennsylvania is given as about 1738. The site of one of the earliest furnaces is still indicated by the old name "Windsor Forges," now transferred to a residence belonging to a descendant of one of the old ironmasters. 
it would be difficult to ensure accuracy of result. Copper, tin, and lead have been mined and smelted in Great Britain from very early dates. Zinc, in the metallic state, was imported from China (or, at all events, from the East) in the early part of the seventeenth century, 'but it does not seem to have been made in England till a century later.

Percy, while he professes himself unable to give a complete history of copper-smelting in England, tells us of early copper-mines in Cumberland and Northumberland, and thinks that the ores were smelted on the spot. But copper was also imported from Hungary and Sweden, while calamine (zinc carbonate) was allowed to be exported as ballast. About the end of the seventeenth and the beginning of the eighteenth century copper-smelting was being carried on in Yorkshire and Lancashire, also a little later in Cornwall, in Gloucestershire, and at Bristol. The date of the establishment of copperworks at Swansea (now the centre of the trade) is given by Percy as 1720, though he states that smelting was carried on in the Principality before that date.

Major Grant Francis, however, in a series of letters to the Cambrian newspaper in $1865,{ }^{2}$ gave

1 Percy's Metallurgy (1861), p. 519.

2 Republished as a pamphlet for private circulation in 1867. (A copy is in the Royal Society of Arts Library.) 
the results of some researches into the early history of Welsh copper-smelting, which show that a furnace was set up at Neath (Glamorganshire) in 1584, and that the work has been carried on continuously down to the present time. Much later, in 1727, works were set up near Aberavon in the same county. At Neath, as was so often the case, the work was started with the aid of German workmen, and a very full history of their proceedings is given among the records published by Major Francis-records, it may be mentioned, which are full of interest to the student of metallurgical history.

The ore treated was partly Welsh and partly Cornish. In later times the bulk of the ore treated at Swansea was imported. From the accounts given, it appears that the processes for crushing, calcining, roasting, and washing the ore, and eventually smelting out the pure metal, were the same in principle, though cruder and more wasteful, than those now employed.

Brass (an alloy of copper and zinc), as distinct from bronze (copper and tin), was known "early in the Christian era, if not before its commencement." 1 But this was doubtless made like early bronze, by mixing the ores before or in the process of smelting. By the middle of the eighteenth century considerable progress had been made in its manufacture. Though brass, 
native and imported, was known in England long before, it is believed that it was not till the reign of Elizabeth that its manufacture was seriously undertaken. From that time forward a great deal of brass seems to have been made from British ores, and a goodly number of brass articles produced. The late $\mathrm{Mr}$ W. C. Aitken, in the account of brass and brass manufacture which he contributed to Timmins' Birmingham and the Midland Hardware District, ${ }^{1}$ gives a very full and interesting account of the growth of the brass industry. From this it appears that by the commencement of the century "battery works," where the metal was battered or hammered into the various shapes desired, had been set up in various parts of the kingdom. One of the most important of these was the company set up at Cheadle, in Staffordshire, and by the middle of the century the manufacture was firmly established in Birmingham, Bristol, and elsewhere.

The brass was made by a cementation process - that is to say, the copper was mixed with calamine (native carbonate of zinc) and the mixture melted in a crucible. This method was employed till very many years later, when the modern process of melting metallic zinc with the copper was introduced. The fact that zinc could be reduced from its ores was known in 
Europe early in the century, and about 1743 works for the purpose were established in Bristol by William Champion. The process of brassmaking was for some time kept secret, but was afterwards published. Dr Percy says it was the same as that in operation at Bristol at the time when he wrote (1861). The metal was run into ingots, which were hammered or rolled out if sheet-metal was required, or used for casting if the articles were to be cast. Such was the state of the industry about 1750. After that it developed rapidly, the process of stamping out articles with dies was introduced, and the manufacture of brass goods became one of the staple industries of Birmingham.

In mediæval times wire, both of brass and iron, was shaped under the hammer. The method of "drawing" it through a perforated draw-plate dates from the fourteenth century in Germany and the sixteenth in England. At first it was drawn through the plates by hand, then by horse-power, and afterwards by waterpower. In the eighteenth century brass wire was made to a large extent in Birmingham. Steel wire, which was required for pianofortes (first made in London about 1766), was imported from Nuremberg. It is said not to have been made in England till much later. ${ }^{1}$

1 Timmins, Birmingham, etc., pp. 318 and 592. 


\section{Tin.}

Tin is certainly the most ancient of British exports. It was mined in this country before Britain was known to the Romans, and was brought by the Phœnicians from Cornwall and Devon, the Cassiterides (Tin-lands), far beyond the Pillars of Hercules. For centuries England had what was almost a monopoly in supplying tin to the civilised world, the amount mined in Cornwall and the west of England growing steadily both in bulk and value, until the discovery by the Dutch of large supplies of tin in Banka, Sumatra, whence it was first imported into Europe about 1787.

The most important application of tin is to the coating of iron-plate, to produce what is known as tinplate or tinned plate, and is now popularly termed tin. Until the middle of the seventeenth century this manufacture was not known in England. English tin was exported to Saxony, where it was used to coat plates which were sent to England. That ingenious projector and author, Yarranton, found out the German methods, and established a factory in the Forest of Dean, where plates were made, better, it is said, than the German productions. It seems likely that the secret lay in rolling out the iron, previous attempts having been made with hammered plates. From this date, the 
manufacture of tinplate, and the use of rolls for the purpose, appear to have been established in England. By the middle of the eighteenth century the industry seems to have been in a flourishing condition in Staffordshire. ${ }^{1}$ Wolverhampton was its headquarters, and a considerable amount of the lighter and cheaper tinwares was then made at Bilston.

Tin was also an important ingredient in the alloys of copper, such as bell-metal and gunmetal; but there does not appear to have been any special progress made in the ancient methods of making such alloys, or in casting them, about the period with which we are concerned. The history of the copper alloys would certainly be of very great interest, but it looks as if the materials for such a history would be hard to collect. Bell-metal is, as is well known, an alloy of copper and tin, in the proportion of about five or three to one. The art of bell-founding is of immemorial antiquity. In the Middle Ages it was found easier to cast a big bell in the immediate neighbourhood of the church tower in which it was to be hung than to carry it for any considerable distance. Even in 1762 the great clock bell at Canterbury was recast in the cathedral yard. ${ }^{2}$ The craftsmen travelled from place to place, and the manufacture had no great settled centres of production. In

1 Timmins, Birmingham, etc., p. 117.

${ }^{2}$ Ibid., p. 650. 
Birmingham, bell - founding dates from the middle of the century. The manufacture was an old-established one in Gloucester, and was in a flourishing condition till the later part of the century. ${ }^{1}$

\section{LEAD.}

Dr Percy devotes a few pages in his volume on the metallurgy of lead to a "Historical Notice of Lead-Smelting in Great Britain." The reduction of the metal from its ores is a comparatively simple process, and it might not be untrue to say that the process has been rather developed than radically changed, from the time when Pliny referred to British lead as used for the manufacture of pipes in Rome. Down to some time in the seventeenth century, wind was relied upon for feeding the Derbyshire furnaces, which (as in Pliny's time) were placed on high ground to catch the breezes. Later, bellows driven by water-wheels were employed. ${ }^{2}$

In a paper communicated to the Royal Society, ${ }^{3}$ by $\mathrm{Mr}$ Martyn, an account is given of the method employed in Derbyshire for the smelting of lead, in 1730. A rude furnace built

1 Victoria County Histories (Gloucester), vol. ii., p. 304.

${ }^{2}$ A great deal of information about early lead-mining in England is given in Industrial Resources of the Tyne, etc., pp. 128 et seq., including a list of the counties in which lead ore containing silver was mined, quoted from Sir John Pettus, who wrote in 1670.

${ }^{3}$ Phil. Trans., vol. $x \times x$ vi., p. 31 (1730-1). 
up of rough stones was used, and in this the broken ore was laid with alternate layers of wood-fuel. Draught was provided by bellows worked by water. Though wood (known as "white coal") seems to have been the ordinary fuel, reference is also made to "black coal" and "cowke (or cinders of pit-coal)." Cupola furnaces were introduced into Derbyshire from Wales about 1747. These are identical with those now used. Coal was employed for smelting lead in the seventeenth century, there being two patents (1678 and 1690) granted for this privilege.

Early in the eighteenth century, the Derby lead-mines had been worked down to the waterlevel, and the production fell off, but by the middle of the century (no doubt in consequence of the introduction of pumping machinery) they were becoming more prosperous. ${ }^{1}$

\section{Pewter.}

The most useful alloy at the disposal of our ancestors of a few centuries ago was certainly pewter. 'The composition of pewter is very

${ }^{1}$ A very good account of the history of Derby lead-mining is given in the Victoria County Histories (Derby), vol. ii., p. 323. The artistic applications of lead formed the subject of a course of Cantor Lectures, given in March 1910 by Mr Lawrence Weaver (Journal of the Royal Society of Arts, vol. lviii.). The metal was used, to a considerable extent, in the eighteenth century, for monumental purposes. 
various, but it is really an alloy of lead and tin, the relative proportions of the two metals varying widely. The fullest account of it will be found in the paper read before the Society of Arts in 1894, by Mr Starkie Gardiner, ${ }^{1}$ and the information contained in this paper is usefully supplemented in another, read ten years later, in 1904, by Mr Lasenby Liberty. ${ }^{2}$ From these authorities we learn that (omitting classical references of uncertain accuracy) the use of pewter, both domestic and artistic, goes back to the seventh, or perhaps the eighth century, though no specimens of earlier date than the twelfth are known to exist. For centuries pewter vessels served the purposes now filled by pottery ware, and as the manufacture of the latter developed, so that of the former decayed. "The sixteenth and the early part of the seventeenth century must have been the palmy days of the pewter trade." ${ }^{3}$ After that it fell off. The chief seat of the industry was London. It was also carried on at Birmingham, but not to any large extent. Its downfall was hastened a little later by the introduction (about 1770) of "britannia" ware, made of an alloy of tin, antimony, and copper.

The very beautiful process of "spinning"

1 Journal of the Society of Arts, vol. xlii., p. 627.

2 Ibid., vol. lii., p. 626.

${ }^{3}$ Lasenby Liberty. 
pewter and other soft metal on the lathe does not appear to have been invented until later, after the beginning of the nineteenth century. ${ }^{1}$

\section{Gold AND Silver.}

From the earliest times a certain amount of gold and silver has been mined in Great Britain. Silver is a common impurity in lead ore, and when the amount is sufficient to make it worth while the silver has always been recovered. But unless silver is present in the proportion of some eleven ounces in the ton of lead, it does not pay to extract it by the old practice of cupellation, for long the only method known. ${ }^{2}$ In Stuart times a considerable amount of Welsh silver was obtained, and various districts in Scotland provided at different dates not only silver but a certain quantity of gold. In the fifteenth and sixteenth century gold was obtainéd in Scotland by washing, but this alluvial gold was no doubt soon exhausted, and we hear of a stamping mill for crushing quartz being set up and producing much "small mealy gold," in the time of Queen Elizabeth. ${ }^{3}$ Gold and silver mining was carried on at Leadhills, in Lanarkshire, from an early

1 Timmins, Birmingham, etc., p. 619.

2 Pattinson's well-known method of desilverising lead, now of universal application, dates only from 1829.

3 Early Records relating to Mining in Scotland, R. W. Cochran-Patrick (1878). This book is full of interesting information, but does not go beyond the end of the seventeenth century. 
date, and the production has continued to our own times. Mr W. L. Lindsay, in a paper read before the British Association at Dundee in 1867, expressed the opinion that gold was more extensively distributed in Scotland than was generally believed, and stated that systematic working at Leadhills during the sixteenth century had produced gold to the value of half a million. On the whole, it seems not unreasonable to assume that before the eighteenth century the more abundant supplies of the precious metals from foreign countries had diverted attention from the unimportant British sources from which gold and silver could only be obtained in insignificant amounts, and by considerable expenditure.

The artistic work of the Georgian era in gold and silver, as in other materials, was not of a high order. "The table plate of the reign of Queen Anne is much prized; it is massive, simple, and seems to exhaust the feeling for Renaissance decoration so long maintained and with so much propriety by the sixteenth and seventeenth century goldsmiths." ${ }^{1}$ But a little later the art of the worker in the precious metals came under the influence of French taste, which dominated all English work during the first half of the eighteenth century. ${ }^{2}$ Some fine work was

${ }^{1}$ Gold and Silver Smiths' Work, J. Hungerford Pollen, p. 146.

2 In 1706 a seal and maces were made for and presented to the Corporation of Neath by the Company of Mine Adventurers, one of the Chartered Mining Companies of that date, and it appears 
occasionally produced. Cripps refers with appreciation to an enormous so-called "winecooler" (perhaps really a big vessel which served for washing the forks as they were used at table), made in 1734 by Kandler, a London silversmith, and designed by Jernegan and by Vertue. This eventually found its way to the Winter Palace, where it still is. ${ }^{1}$

In the seventeenth and eighteenth centuries very large amounts of gold and silver plate were melted down, both in England and the Continent, to supply the needs of the owners and of the political factions to which they belonged. Silver plate was regarded as a "reserve of specie" (Cripps), and the reserve was freely drawn upon by all who could get at it. First the Reformation, then the civil war and the Commonwealth, exhausted the stores of convertible bullion. Then large amounts were turned into coin in the reign of William III., and finally the demand for table ware which arose when forks came into use, and when tea and coffee became fashionable beverages, caused a great deal of old silver to be converted into more modern articles of domestic utility.

"When the custom arose, most likely in the early part of the last [eighteenth] century, of the host supplying his own table with the plate

certain that they were made of native silver. See Major Francis' Letters on Swansea Copper-smelting, above referred to, p. 67.

${ }^{2}$ W. J. Cripps, Old English Plate (Sixth Edition, 1899), p. 334. 
requisite for the use of his guests, a much larger quantity was needed, and more as time went on. Mr Octavius Morgan suggests that a great deal of old-fashioned unused plate-ewers and basins and the like-was about a century ago [i.e., in the latter part of the eighteenth century] melted down to supply this want; and that the magnificent services of gilt and silver plate which were then made for royal and other tables were provided in this way. . . . As at that period old plate was not valued, every one was glad to change antiquated silver articles for those of a newer and more useful fashion." 1

It was in this way that the material was provided for the magnificent service of gold plate ordered by George IV. for Windsor, and still used there on State occasions.

According to Cripps, a very large amount of old plate was melted down and fashioned into new dinner services by the London silversmiths. He specially mentions that a great quantity of old plate was exchanged by the City of London for new.

In the reigns of George I. and George II. a large number of tea-pots, coffee-pots, tea-caddies, and tea-kettles were made-first plain, then elaborately ornamented. Cake-baskets and epergnes were also manufactured. The date of production of these things is said to have been for the most part between 1730 and 1780 .

1 Cripps, pp. 334-5. 
Castors and cruet-stands came into fashion early in the century. No doubt much of the old ware was used up again for such purposes too, and it must be borne in mind that there was no fresh source of supply of silver available to meet the increased demand.

What is known as Sheffield plate was the result of a discovery in $\mathbf{1 7 4 2}$ by Thomas Bolsover, and soon after that date the process was being successfully worked on a commercial scale by Joseph Hancock in Sheffield. The process, as is well known, is carried out by welding or fusing together copper and silver ingots, the combined ingot being then rolled into a plate. ${ }^{1}$ The method of "fire-gilding" is much older. To carry it out, the surface of copper, etc., is brushed over with an amalgam of gold and mercury, and the mercury is volatilised by heat.

\section{Coal.}

The use of coal for fuel is referred to in a grant of land to the Abbey of Peterborough in A.D. 853. ${ }^{2}$ Records referring to the existence of collieries in Scotland go back as far as the end of the twelfth century, and there is evidence that in the thirteenth coal was brought to London by

- 1 Sheffield Plate, etc., by S. Cowper - Coles, Journal of the Society of Arts, vol. lv., p. 853. Hunter's Hallamshire, p. 124.

${ }^{2}$ Percy, Iron and Steel, p. 881 . Industrial Resources of the Tyne, etc., p. 16. 
sea from the north. Such coal, besides being used for domestic purposes, was at first used for lime burning, soon after in smiths' forges ; and in later times for the smelting of copper and lead, in furnaces for the manufacture of pottery and glass, for drying malt, for making salt, by brewers, and for other industrial purposes.

Curiously enough, many of the earlier references to coal are due to its objectionable qualities. Its smoke and smell were disapproved of, and not without reason. In 1306 there was a Royal Proclamation against the use of coal in London, and there were many complaints about its smoke in later years. As its employment became more popular, it became an article of commerce, and in 1563 an Act of Parliament prohibited its export, either in the form of ballast or otherwise. By the middle of the eighteenth century it was of course worked on a large scale. As the shafts of the collieries grew deeper, in the effort to comply with the growing demand, fresh difficulties were encountered. The deepest shaft in $\mathbf{1 7 5 4}$ appears to have been that at Whitehaven, which reached a depth of 130 fathoms (or about 800 feet); and this must have been quite exceptional, for probably hardly any coal was worked at a greater depth than 100 fathoms. ${ }^{1}$ At the

${ }^{1}$ Wills' Cantor Lectures on Explosions in Coal-mines (1878). Journal of the Society of Arts, vol. xxvi., p. 458. Galloway, History of Coal-mining. B. H. Brough, Mining at Great Depths, Journal of the Society of Arts, vol, xlv., p. 57. 
present time there are mines which approach, or have reached, the depth of 5000 feet, or nearly a mile.

Early in the eighteenth century fire-damp began to claim its victims. Its existence had been recognised long before, but very little was known about its nature. There were, in the first half of the century, several serious explosions, with a considerable loss of life. The earliest effort to improve matters by ventilation was made about 1732, when the first attempt was made to produce a draught by means of furnaces. Between that date and 1754 considerable improvements were made in ventilation, and at that time, or a few years later, something like the modern system had been introduced by Spedding.

The great danger connected with fire-damp was, of course, the use of naked lights. From the earliest times lamps and candles were employed, and miners had got to be very expert in detecting the presence of fire-damp by the use of the latter. ${ }^{1}$ When it was found that the use of naked lights was dangerous, attempts were made to provide a light which would not fire the inflammable gas. The best of these was the "steel mill," the date of which is probably somewhere between 1740 and 1750. This apparatus was introduced by Spedding, in conse-

${ }^{1}$ Wills' Cantor Lectures, Journal of the Society of Arts, vol. xxvi., p. 474. 
quence of some experiments by Sir James Lowther, which seemed to show that fire-damp was not ignited by sparks from a flint and steel. It consisted of a steel disc rotated by hand, against which a flint was held. The result was a shower of sparks, which gave a very faint dim light, and for long it was erroneously believed that the apparatus was not capable of firing the gas. Nothing better, however, was known until Dr Clanny's lamp in 1812, the precursor of the safety lamps of Davy and Stephenson.

Another great difficulty - perhaps the greatest felt by the miner-was that of keeping the mines free from water. From the early part of the century Newcomen's steam, or rather atmospheric, engine had been successfully used for this purpose, all other attempts at pumping having been found quite unable to deal even with the short shafts then existing.

About 1741, the system of screening coal was introduced by William Brown. Though a more merchantable article was thus produced, the method resulted in a great deal of waste, large quantities of unsaleable small coal being burnt. ${ }^{1}$

In the earliest coal-mines, the mineral had been raised to the surface by men climbing ladders, or in baskets worked by horse-gins ; but the successful use of the steam-engine for pumping suggested its application to haulage, and

${ }^{1}$ Industrial Resources of the Tyne, etc., p. 27. 
about 1753 attempts were being made to apply it to this purpose. In the earliest of these, "a basket of coals was raised by the descent of a bucket of water, the steam-engine being employed to re-pump the water to the surface." 1

Later in the century, the hardly less clumsy method was employed of pumping water to a height, and causing it to work water-wheels, which served to wind the coal to the surface. This roundabout and costly device was coming largely into use, when the application of the crank to the steam-engine enabled the necessary rotation of the winding drum to be obtained direct from the engine.

It is in all probability not very generally known that until quite the end of the eighteenth century, the workers in Scotch coal-mines were absolute slaves or serfs; and it is a remarkable fact that the slavery of these colliers continued after the celebrated legal decision in 1772, that a negro slave landing in this country became free. ${ }^{2}$ The subject is treated rather fully by Cosmo Innes, in an Appendix to his Sketches of Early Scotch History (1861). ${ }^{3}$ He seems uncertain how the custom originated, and does not think it was a vestige of mediæval serfdom, which had apparently died out before the Scotch mines were

${ }^{1}$ Galloway, History of Coal-mining, p. 112.

2 Sir T. Erskine May, Constitutional History of England, vol. iii. (Seventh Edition, 1882).

${ }^{3}$ Page 498. 
worked. But however the custom arose, it is certain that up to $\mathbf{1 7 7 5}$ the colliers (and also the salters) were literally and legally slaves. A child who did not enter the mine was free, but with this almost nominal exception the colliers were born into slavery, and continued slaves during their lives. They were sold with the mines, and were under the absolute dominion of the owner, so long as he did not kill or torture them. In 1775 an Act was passed for their gradual liberation; but this seems to have been ineffective, and the practice was only abolished by another Act of 1799 .

Hugh Miller ${ }^{1}$ gives a graphic description of the state of things in the mines near Niddry (Midlothian) and Musselburgh, obtained from men who had themselves worked as serfs in those mines. He speaks of the date when he talked with them as being forty-nine years after the Act of 1775, which would make it 1824, and he adds that one man who had worked as a serf in the Musselburgh mines gave evidence in $\mathbf{1 8 4 2}$ before a Parliamentary Committee.

Cosmo Innes refers to Miller's account, and also quotes an interesting passage from Lord Cockburn's Memorials of his Time, which gives a summary of this queer bit of history, though it

1 My Schools and Schoolmasters (Edit. 1860), pp. 317 et seq. Miller died in 1856. The first edition of his book was published in 1852 . 
adds nothing to the information provided by Innes and Miller.

\section{QUARRIES AND Stone-Mining.}

There does not seem to be very much to be said on this subject. The methods employed in quarrying and dressing stone appear to have been the same as they were for centuries before, and as they now are, except, of course, that steam-power was not employed. Blasting with gunpowder was in common use. The sources from which British building stones, marble, granite, slate, etc., were obtained have for long been the same. Railways, as is well known, took their rise from tram-roads originally laid down for the conveyance of coal, ores, and stone. They were in the first instance of wood, and such tramways were in use in the seventeenth century for horse traction. Later (about 1770), iron rails were laid down, and these were fitted with flanges to keep the wheels on the track. Later still the flange was transferred from the rail to the wheel. 


\section{CHAPTER V}

Glass-Pottery and Porcelain-Watchmaking-Paper-Printing and Bookbinding-Furniture, Carpets, etc.

\section{GLass.}

From a very early date glass had been manufactured in many places in England and on a considerable scale. Most of this early glass was inferior, greenish in colour, and principally used for windows, though drinking-vessels of tumbler shape were also produced of the same material. ${ }^{1}$ At the date with which we are dealing large amounts of this same glass were being made in London, Newcastle, Birmingham, and elsewhere. ${ }^{2}$

The materials employed were sand or "rock"

1 Hartshorne, Old English Glasses (1897).

${ }^{2}$ Mr E. W. Hulme has published in the Antiquary, vol. xxx., pp. 210 and 259, and vol. xxxi., pp. 68, 102, and 134 an interesting series of articles on early Englis glass, in which he gives the results of his careful and elaborate investigations into the subject. He has satisfied himself that the only authenticated seat of the glass industry in England before 1585 was Chiddingfold in Surrey. In Elizabeth's reign glass-making spread rapidly owing to the introduction of Huguenot and Italian glass-makers, and at the end of the seventeenth çentury the industry was well established. 
(ground sandstone), and a crude alkali procured from the ashes of plants. In this country the best alkali was obtained by burning kelp, and the collection and burning of that plant was a considerable industry on the coasts of Ireland and Scotland, until the discoveries of Leblanc in 1792 enabled salt to be converted into carbonate of soda, and so put an end to the treatment of ashes for the potash and soda they contain. For making the commonest sort of green glass for glazing purposes the ashes of various plants were employed, fern being one of the most common. The ashes of kelp were not only rich in alkali, but contained a large proportion of lime, which was a necessary ingredient.

The best alkali, known as barilla, soda of alicante, etc., came from the East, and was produced by burning kali (hence, of course, the name alkali), plants of the genus salicornia, or glasswort. This Eastern alkali was used in Venice, Bohemia, and France, and there is evidence that it was imported here also for the better sorts of glass. Saltpetre, either imported or obtained from accumulations of animal and vegetable refuse (nitre-heaps), was also occasionally used. The use of manganese for improving the colour of the glass was well known. As a contemporary writer ${ }^{1}$ quaintly puts it, it served "to purge off the natural green colour."

$$
1 \text { Chambers'. Cylopoedia (1751), art. "Glass." }
$$


The most important feature, however, of the English glass manufacture, in the middle of the century, was certainly the production of what is still known as "flint" glass, and was at the time also commonly called "cristal" or "crystal." This was far whiter and more brilliant than any glass which could then be made by other methods. It was employed chiefly for making drinking vessels, but also for mirrors. The name "flint" arose from crystal glass having originally been made from crushed flint, which provided a nearly pure form of silica. The so-called "flint" is really a lead glass. The best authorities seem to hold that the use of lead was first proposed in England some time in the seventeenth century, though neither the name of the inventor nor the precise date of the invention is known. ${ }^{1}$

Nesbitt thinks the glass-works established by Sir R. Mansell, near Newcastle, under his patent of $1614^{2}$ owed their success to the use of lead,

${ }_{1}$ Nesbitt, Glass Vessels in the South Kensington Museum (1878); Hartshorne, Old English Glasses; Encyclopoedia Britannica, etc. Mr Noel Heaton, in his paper on "The Foundations of Stained:Glass Work" (Journal of the Royal Society of Arts, vol. lviii., p. 456), prints an analysis of some mediæval glass from York Minster, which shows a percentage of 0.6 lead oxide. The amount is so small that it looks as if the lead might have been an accidental impurity.

2 These works were carried on from about 1616 to the middle of the nineteenth century. The glass made then was crownglass. 
but Hulme disputes this view. He maintains that lead glass was first manufactured in this country, and quotes as the earliest reference he can find the specification of Oppenheim's Patent of 1755 (No. 707). He agrees that the invention was an English one, and it seems that England had for long a practical monopoly of the manufacture. Hartshorne quotes a French writer as his authority for the statement that in $\mathbf{1 7 6 0}$ English flint glass makers sent four-fifths of their output abroad, the whole of France being supplied with flint glass from England. The same author, in his sumptuous volumes above mentioned, figures and describes many beautiful examples of English eighteenth-century work, much of which still exists, though he laments the fact that nearly all the earlier productions have perished. Before the development of the industry in England there was a considerable business in the importation of Venetian glassware; but as the decay of the Venetian manufactures coincided in time with the improvement of English production, this importation diminished, and had apparently come to an end by the middle of the century. None of the English ware ever equalled in beauty of design the best products of the Murano artificers, but the glass itself of the ordinary ware was better than any except the best Venetian and Bohemian.

The method of making glass-ware was then 
the same as had been used for centuries in Venice and elsewhere, and as is in use to-day, though with more elaborate appliances. Coal was everywhere employed, though it was burnt in furnaces of a simpler character than the modern furnace. The glass-blowers' tools were much the same, except that modern laboursaving devices were unknown. For windows, both sheet and crown glass was available, made in much the same way as now. What was then called plate-glass was not what we now know by that name, but blown plate, made much in the same way as sheet glass, but very much thicker. The largest plate made at the time could not exceed 45 inches in length, with a breadth of 30 inches. Plate-glass, made by throwing the molten material on an iron or copper table, and afterwards rolling it out into a plate of equal thickness, had been known in France since 1688, and had been imported from St Gobain, but was not made here until the Company of British Plate Glass Manufacturers was incorporated by an Act of Parliament in 1772 and started works at St Helens.

The principal use of plate-glass, both in its earlier and in its modern form, was for lookingglasses. Glass mirrors are said to have been invented in Murano in 1507, and looking-glasses certainly came into general use in England after the Restoration. Nell Gwynne's house in St 
James's Square had a room of which the walls were lined with looking-glass, no doubt after the same fashion as in the Galerie des Glaces at Versailles. ${ }^{1}$ The manufacture was carried on here by Venetian workmen who were brought over for the purpose, and by their pupils. Such mirrors were frequently bevelled and mounted in carved frames. The bevel at this time was ground with very considerable skill. The silvering was effected by the old amalgam process -tinfoil and mercury. Among the products of a "battery works" 2 about 1700 is mentioned "rolled tin in leaves for foils of looking-glasses." 8 The method of silvering mirrors described in Chambers' Cyclopoedia is identical with that which was used until quite recent years.

In $\mathbf{1 7 3 7}$ there were four factories in existence in Newcastle for the manufacture of glass bottles. The material employed was obtained from an extensive fluvial deposit at Jarrow Slake. This consisted chiefly of "siliceous, calcareous, and

${ }^{1}$ Steele, in his Lover, No. 34 (1714), praising up Gumley's Glass Gallery, over the New Exchange, speaks of the "incredible improvements our artificers in England have made in the manufacture of glass in thirty years' time," and adds that "it is not in the power of any potentate in Europe to have so beautiful a mirror as he may purchase here for a trifle." Steele also inserts a puff of the wares of his "diligent friend and neighbour, $\mathrm{Mr}$ Gumley," in No. 509 of T'he Spectator (1712).

${ }^{2}$ Works at which tin was "battered "or hammered out.

3 Timmins, Birmingham, etc., p. 265. 
argillaceous earths in excessive comminution, united with carbonaceous and saline matter." 1

Hartshorne thinks there was little or no glass-cutting done in England before the middle of the century, but refers to some fine work produced in 1758.

The making of windows of stained and painted glass is not an industry but an art. Still, in an attempt, however summary, to indicate the condition of the manufacture of glass in a particular country at a particular period, this application of glass cannot be passed over, though, as is certainly the case at the time with which we are concerned, there is little that is good to be said of it. Long before, the technique, both of the maker of coloured glass and of the artist in it, had reached its highest development. Modern chemistry has increased the number of new colours available, and discovered new materials for the old colours. It has added the oxides of uranium, chromium, and iridium to those of gold, silver, copper, cobalt, iron, manganese, and tin, the principal colouring matters which the old glass-maker found would stand the heat of the furnaces, and would give to his glass the gorgeous colours he required. But the middle of the eighteenth century was not marked by any knowledge of chemistry or by much application of art.

${ }^{1}$ Industrial Resources of the Tyne, etc., p. 201. 
Speaking from an artistic standpoint, the late $\mathrm{Mr}$ Lewis Day ${ }^{1}$ characterised eighteenthcentury glass as "not of sufficient account to be classed separately ;" and again : "The history of eighteenth-century windows may, if one may plagarise a famous bull, be put into the fewest possible words : there were none-worth looking at. To find pleasure even in Sir Joshua's design at New College, you must consider it as anything but glass." 8

In answer to a request for information, $\mathrm{Mr}$ Day most kindly furnished the writer with the following interesting note. It may be taken as embodying the views of one who was at the time the best living English authority on the subject $^{4}$ :-

"In the first half of the seventeenth century, the Van Linge family were doing the only fairly good glass in England which depended like all work of that date upon enamel colour-whereas until well into the sixteenth century the colour was pot metal chiefly, i.e., the window was a mosaic of pieces of coloured glass-painted only

1 Windows (Third Edition, 1909), p. 315.

2 Page 229.

${ }^{3}$ Sir Joshua Reynolds designed the window in the antechapel at New College, Oxford, in which the Virtues are represented.

- Before these words were in print, Mr Day's sudden and untimely death deprived his art of an earnest student, and the author of this treatise of a valued friend. 
to give detail, shading, etc. Following the Van Lingen in England were the Prices in the early part of the eighteenth century, and later, Peckett, of York; but theirs was poor stuff. When, about 1777, Sir Joshua Reynolds set about his window in New College, Oxford, the art of glass painting was so dead that, for painting it, he had to employ a pottery painter, one Jervais. Sir Joshua and those advising him knew no better than to glaze up the window in big rectangular panes, and paint on the white glass, much as if it had been porcelain, or, for that matter, canvas -in that way obscuring the brilliancy of the glass and failing to get its fine colour. That is to say, the tradition of glass window-making was lost, only to be revived with the Gothic revival. Such as it was, the technique of the period consisted in painting upon glass just as they might have painted on anything else-only, of course, in vitreous colours, which were fixed by firing, but so insecurely that the pigment has long since begun to wear off.

"There were no glass painters in any artistic sense. The country glazier did his little bestand it was not worth mention."

\section{Pottery and Porcelain.}

While the art of pottery-making had made considerable advance in Spain, Italy, France, and Germany, it remained, until at all events quite the end of the seventeenth century, in a very backward condition in England. In the time of 
Queen Elizabeth there was established a considerable manufacture of pottery in Staffordshire, a district with its various clays and grit "prepared by nature for the staple it must produce," and some of this was of a decorative character. As far back as Saxon times, much beautiful tile work was produced in England, and this continued till the twelfth, or even till the thirteenth century. But this manufacture died out, and for centuries little but common and inferior pottery, "peasant pottery-made by peasants for peasants," ${ }^{2}$ was made here. Towards the end of the seventeenth century there was a revival. It was about 1670 that $\mathrm{Dr}$ John Dwight commenced the production at Fulham of the very beautiful examples of stoneware and terra-cotta which, in Mr Burton's opinion, "place him in the front rank of men who are honoured as original potters." Yet, according to the same authority, Dwight's direct influence on the improvement of English pottery seems to have been singularly small. His indirect influence may have been greater. Authorities differ as to the authors of the different improvements introduced about this time, but the latest and most trustworthy of them, Professor Church and Mr Burton, claim for Dwight much that had previously been attributed to other

1 Meteyard, Life of Wedgwood,ivol. i., chap. iv., p. 96.

2 Burton, History of English Earthenware (1909), p. 4. 
inventors. Among such improvements may be mentioned the use of salt for glazing in place of the galena (sulphide of lead) previously used, the employment of metal stamps or moulds for impressed ornaments, and the use of calcined flint for whitening the ware. Considerable improvements are supposed to have been introduced by two German brothers, named Elers, and afterwards by Astbury, who, according to accepted traditions, obtained a knowledge of their processes by fraudulent means.

Towards the close of the seventeenth century, some specimens of the fine red ware, "buccaros," of China and Japan were imported, and the English potters tried to imitate them, with remarkable success, in the pieces attributed to Dwight and Elers. A new ware, "Crouch ware," was made in some quantity from a whitish clay found in Derbyshire. "Slip-decorated ware," ornamented with light-coloured slip on a dark body, had been made for a long time at Wrotham in Kent, and elsewhere. Large amounts of Delft ware came into England by way of the eastern ports, Hull, Harwich, and Yarmouth; and, indeed, till well on towards the middle of the eighteenth century, England, in spite of the growing production of "delft" at Lambeth, Liverpool, and Bristol, was mainly dependent on France and Holland for all but the commonest kinds of earthenware. Ordinary 
English earthenware had many defects - bad colour, imperfect glaze, and liability to crack.

In the first half of the century a good many improvements were introduced, in materials, methods and processes, as well as in artistic treatment. The demand increased, and the whole trade became more systematised. Plaster moulds were introduced from France about 1740. The grinding of flints by edge-runners driven by a water-wheel was patented by Thomas Benson in 1726. The potter's wheel was improved and the use of the lathe introduced. From 1730 to 1760 there had been a considerable increase in the trade, and during that period the population of Stoke-upon-Trent had nearly doubled. Some important works were started between 1730 and 1740 at Gateshead. ${ }^{1}$ By 1762 there was a considerable export of ware from London, Hull, Liverpool, and Bristol to America, the West Indies, and the Continent. ${ }^{2}$

Porcelain was only known as an importation from the East, where the secret of its manufacture from kaolin, or china-clay, was jealously guarded. Originally introduced into Europe by the Portuguese, it was afterwards brought over by the Dutch and our own East India Companies.

1 Victoria County Histories (Durham), vol. ii., p. 312.

${ }^{2}$ Meteyard. It seems not unlikely that the bulk of this went to America, and perhaps a proportion of it was Continental and Eastern ware imported into England and re-exported. 
For many years large consignments of Eastern porcelain were brought to England by the Company. The first examples of this, no doubt, went into the cabinets of collectors-the collection of Oriental china was long a fashionable craze, and Horace Walpole was its chief apostle-but the great bulk of the ware was distributed for domestic use, and perished in the using. It furnished the tables of well-to-do and tasteful folk, especially their tea-tables, since the demand for it for dinner services seems not to have been so large. Pewter was then largely used for plates, and in humbler homes the wooden platters and bowls still held their own.

Later there arose a fashion for "armorial" services-services, that is, decorated with the armorial bearings of the owner or recipientspecially made in China and brought home. Sir George Birdwood, in that splendid and charming book, Relics of the Honourable East India Company, of which he is one of the joint authors, refers at length to those curious products of East and West combined, and remarks that the rarity of these and other examples of Eastern contemporary ware, considering " the immense trade in porcelain carried on by the Honourable East India Company throughout the eighteenth century," shows that the ware was imported for use and not for show. $\mathrm{He}$ mentions "the widespread destruction to 
which these vast accumulations of porcelain were exposed, through the contempt bred by the ubiquitous presence and incessant use of them."

During the first half of the century attempts to imitate the Eastern china were made on the Continent. The French porcelain of St Cloud, Chantilly, Vincennes, and afterwards of Sèvres, attracted great attention. So, too, did the Meissen porcelain. At Dresden a soft paste was made of materials which are not known, until the introduction of some kaolin, from Virginia, and the accidental discovery of a supply of this material, rendered possible the production of a hard paste like that of Oriental ware. At Meissen the famous Böttger established the manufacture of true porcelain allied to the Chinese. In France, an artificial substitute containing a little clay and much glass was made at St Cloud. Other famous French porcelains of the same character were made at the works above mentioned, the Sèvres works being established as a royal factory by Louis XIV., in 1756. Here, also, the discovery of kaolin enabled hard paste to be made in 1759 .

England followed suit a little later. The precise date seems, according to the best authorities, to be uncertain. It may be taken to have been some time before 1740. The works at Bow are said to have been using kaolin from America in 1744. The inspiration 
which led to their establishment is shown by their name "New Canton." A few years later the Chelsea works were producing English china in imitation of Dresden ware from various materials. Between 1760 and 1765 many works of great beauty were produced at the Chelsea works. In 1753 Cookworthy, a Plymouth Quaker, discovered kaolin in Tregonning Hill, and attempted to profit by his discovery by setting up works at Plymouth. These were not very successful, and he migrated to Bristol. The great deposits of china-clay thus made known proved, however, of immense value, and still continue to be the principal British source of this most important material.

"Various attempts to make porcelain in the neighbourhood of London culminated in the factories of Bow and Chelsea, both of which were active as early as 1745 . The ware was a soft-paste porcelain, the secret of which had been learnt, no doubt, from French potters. Shortly after 1750 other factories sprang up at Derby, Worcester, Lowestoft, Longton Hall, Bristol, and Liverpool. All the early English porcelains were varieties of soft-paste, some distinguished by the admixture of bone-ash, and others by that of steatite. The only true hard-paste porcelain was made of Cornish materials at Plymouth from 1768-70, and at Bristol from 1770-81." 1

${ }^{1}$ Burton and Hobson, Marks on Pottery and Porcelain (1909), p. 93. 
The result of all these attempts to reproduce, or to find a substitute for the old felspathic porcelain of the East, appears to have been the production of that new variety of porcelain, which Mr Burton classifies as a phosphatic or bone porcelain. It was invented in England at this time, and is now produced, not only in England, but in many other countries of Europe and in America. It is made "of a true porcelain paste, which has been rendered more fusible by the addition of a large proportion of calcium phosphate in the form of bone-ash." ${ }^{1}$ The production of ware made of this material must certainly be laid to the credit of the English potters of the latter part of the century. ${ }^{2}$

The art of decorating pottery by transferring to the surface designs printed on paper was introduced by Sadler and Green of Liverpool, in 1752, and a few years afterwards they were doing a large business. These earliest transfers were from engraved copper-plates printed in black, red, or purple on the surface of the fired glaze. Wedgwood sent much of his Queen's ware to Liverpool to be decorated by applied prints at Sadler and Green's works.

1 Burton, Porcelain, page 7.

$2 \mathrm{Mr}$ Burton (Porcelain, page 6) recognises three varieties of porcelain:-1. Natural felspathic porcelain, made originally in China and Japan. 2. Artificial glassy porcelains, made in Europe in the eighteenth century. 3. Phosphatic or bone porcelain, invented in England in the eighteenth century. 
Though there seems no reason to doubt the originality of the invention, it had partly been anticipated by the use of similar transfers at the Battersea enamel works about 1750. The very beautiful productions of Battersea were, however true enamels on metal, not pottery. ${ }^{1}$

About this date many factories were established in various parts of the country for the manufacture of various sorts of pottery and porcelain, and some of these have developed into the great potteries of the present time. Thus, in 1770, Josiah Spode founded the factory at Stoke-on-'Trent, which much later passed into the hands of Copeland. The Bow works and the Chelsea works were transported to Derby. The works established at Worcester by Dr Wall eventually became famous as the "Royal Worcester Porcelain Works." Potteries were also established at Caughley, Shropshire, in 1751, at Leeds in 1760, at Gateshead between 1730 and 1740, at Coalport in 1780, at Swansea in $\mathbf{1 7 6 9}$, and at Lowestoft in $1756 .^{2}$

It will thus be seen that by the time with which we are concerned English pottery had already started on its upward progress. The advances it had made were due to the effects of

1 The Battersea enamels are well known to collectors and are highly valued. There are many fine examples in the British Museum.

2 This seems to be the correct date, though Burton and other authorities give 1757. The point is not now important. 
a number of ingenious, skilful, and industrious potters who introduced "new materials for the body and glaze of their staple, and new processes and appliances in manufacture." 1

Finally came the greatest of English potters, Wedgwood, who about 1762 brought out his "cream-ware," afterwards, on the presentation of a caudle-cup to Queen Charlotte, known as Queen's ware, and later (about 1773), the beautiful ware still known by its maker's name, and associated also with the name of Flaxman, from the designs which that great artist supplied for it. Wedgwood started business on his own account in 1759, and moved in 1769 to the works he called "Etruria" (Stoke-upon-Trent). Here it was that the vast abundance of beautiful pottery was made which, in the later years of the century, was exported all over the world, and for the first time in history put the productions of English potters ahead of those of any of their contemporaries, and on a level with those of any of their predecessors.

\section{WATCHMAKING.}

During the eighteenth century the art of horology reached a high level in this country. Tompion, "the father of British watchmaking," died in 1713, but his friend and successor, Graham, lived until 1751. Both were buried in

1 Meteyard, vol. i., chap. iv., p. 166. 
Westminster Abbey. Graham invented the mercurial pendulum for compensating variations of temperature, and described it before the Royal Society in 1726. The lever compensation pendulum, acting by the different expansions of brass and steel, and commonly called the "gridiron pendulum," was invented by John Ellicott about 1735. In 1728 John Harrison showed his first chronometer to Arnold, who gave him the good advice that he should go back home into the country and perfect it. This he did, and in $\mathbf{1 7 3 5}$ he brought it up to London again to enter it in competition for the reward offered by an Act of Parliament passed in 1714, which promised $£ 10,000$ to the inventor of a chronometer capable of determining within certain limits of accuracy the longitude of ships at sea. The following year (1736) the Board of Longitude gave him $£ 500$ after an experimental voyage, and in 1761 the chronometer was more completely tested by a voyage to Jamaica, when the Board awarded Harrison the full prize, though he did not get paid the whole of it till 1769. In 1749 he received the Royal Society's Medal. Mudge (1715-1794) and Arnold (17341799) improved Harrison's chronometers, and practically brought them to their present form. ${ }^{1}$

Many of the clocks and watches made by these and other skilled mechanicians of the period are

${ }^{1}$ F. J. Britten, Former Clock and Watchmakers. (1894). 
still keeping good time, and the work of these men, though sometimes a little lacking in finish, will bear comparison not only with that of their contemporaries in other countries, but with that of any who have succeeded them. ${ }^{1}$

Akin to the work of the clockmakers was that of the skilful mechanicians who devoted their energies to the production of automata. Several of these flourished during the eighteenth century, but they were none of them Englishmen, though their works were sometimes exhibited here. Vaucanson (1709-1782) was one of the most celebrated of these, and Von Kempelen, who made the automaton chess-player in 1776, was another. It seems strange to us who are accustomed to see so much done by machinery, that such ingenious mechanicians should never have applied their genius to the construction of anything more useful than these extremely clever toys. $^{2}$

1 The clock in the Society of Arts meeting-room was presented to the Society in 1760 by Thomas Grignon (1740-1784), a clockmaker of considerable reputation in his time. It is still an admirable time-keeper, and seems none the worse for its hundred and fifty years' service.

2 One of the quaint "Opuscula" issued by that genial fellowship the "Sette of Odd Volumes" is devoted to Automata Old and New (1893). It was written by Mr Conrad Cooke. There is also an article in the first number of the Chess-player's Chronicle (1841), believed to have been written by Staunton, the great chessplayer, which gives an entirely different explanation of the method by which this celebrated automaton was worked. The late $\mathrm{Mr}$ Danby Fry, who knew Staunton well, has left on record in 


\section{PAPER.}

The first paper mill in England is believed to have been that of John Tate, of Hertford, which was at work in 1490 . A hundred years later, in 1588, a mill was established at Dartford by Spielman, a German, who obtained from Queen Elizabeth a license "for the sole gathering for ten years of all rags" for paper-making. ${ }^{1}$ But the industry does not appear to have flourished, and all the best paper was imported. The writer of the article on paper in the French Encyclopédie says :-

"La Grande-Bretagne, dans le dernier siècle, tiroit presque tout son papier de l'étranger. Elle ne date son premier moulin de papier, bâti à Dartfort, que de l'an 1588. Un poëte de ce tems-là le consacra par des vers à son honneur : présentement l'Angleterre a compris que la vraie consécration des choses utiles consistoit à les multiplier; aussi tire-t-elle aujourd'hui peu de papier de l'étranger." 2

According to the Report of the Juries of the 1851 Exhibition, up to the middle of the eighteenth century "only very common paper, principally wrapping, was made in Great

a private letter to $\mathrm{Mr} \mathrm{H}$. B. Wheatley his opinion that this explanation was the correct one.

${ }^{1}$ Richard Herring, Paper and Paper-making (1855).

2 Vol. xi. of the Encyclopédie, p. 858 (1765). 
Britain." It was not till 1740 that Whatman started fine paper-making at Maidstone, after learning the art abroad, either, according to the Report, as a journeyman in some of the Continental factories, or, as Herring prefers to record, "by travelling in the suite of the British Ambassador to Holland."

Before this date, as stated in the above extract from the Encyclopédie, all the better class paper, intended for fine book-work, was imported, principally from Venice and Genoa. ${ }^{2}$

It is, at all events, certain that up to 1750 , little advance had been made here in the processes by which paper was made. Moulds made of woven wire, as distinguished from moulds made of wires laid across one another, were introduced about this date. It is said that the first book on "wove" paper was the edition of Virgil printed by Baskerville in $1758 ;{ }^{8}$ but this is considered doubtful, and the volume of the Philosophical Transactions for 1788 (or part of it) is generally believed to have a better claim to be considered the oldest book printed on paper made in this

${ }^{1} 1851$ Exhibition Jury Reports, p. 427.

${ }^{2}$ Rhys Jenkins, article in Library Association Record, vol. iv., pt. i., p. 134 (1902). This is one of a series of articles by the same author, which contains a great deal of interesting iuformation about the early history of paper-making in England. The article above quoted deals with the history of paper-making from 1714 to 1788. In 1775 Whatman was exporting paper, and paper of large size.

${ }^{3}$ Power's Handy Book about Books (1870), p. 41. 
manner. ${ }^{1}$ The rags - and rags were then the only available material for paper-were reduced to pulp by stamps, driven usually by water-power, and the paper itself was all made by hand. It was not until the early part of the nineteenth century that machines capable of making paper in continuous lengths were introduced by the genius of Fourdrinier.

\section{Printing and Bookbinding.}

Hansard in his Typographia ${ }^{2}$ tells us :"The glorious works of English literature which immortalised the reign of Queen Anne were originally presented to the public through the medium of Dutch Types," but the skill and artistic capacity of Caslon about 1720, or soon after, provided this country with a fount of type superior to that of any of his foreign contemporaries. The importation of type ceased, and "from 1720 to 1780 few works were printed with the types of any other foundry." 3 Amongst these few were certainly the beautiful editions printed by John Baskerville from type cut by himself. Baskerville carried on his business in Birmingham from about 1745 to 1765 . The excellence of his productions depended not only on the beauty of the type, but on the trouble he

${ }^{1}$ See Rhys Jenkins' article above quoted.

2 Page 347.

3 Typographia, p. 350. 
took to obtain the best paper and the best ink. There was, indeed, a revival of printing in England about the middle of the century. The University Press at Oxford turned out a good deal of very beautiful work, and the Cambridge Press also was fully occupied. The presses employed showed no great advance on those used for the two previous centuries. The ingenious and eminent Dutch cartographer, Blaeu, had improved the old press in the seventeenth century, and his presses were introduced into England at some time during the early years of the eighteenth; but, until the third Earl Stanhope (1798) invented his greatly improved iron press, no very important changes seem to have been made. Presses were of wood, with a slab of stone or marble set in a frame (called the coffin) of wood.

Printers made their own ink. The old manuals give detailed instructions for the manufacture. The ingredients were boiled linseed oil and lampblack. Later resin was added. Hansard $^{1}$ gives Baskerville the credit of being the first to improve the ink which had satisfied his predecessors for two hundred years. He certainly added resin, but his chief care was to obtain very fine lampblack. After his death (in 1775) his process " remained dormant" till 1790, when it was revived and utilised by Bulmer.

1 Typographia, p. 117. 
Up to the middle of the century there was not much English bookbinding which could compare with the sumptuous productions of the great French binders, though there was much excellent work, and some examples which are very highly esteemed by those capable of forming an opinion. But in 1766, or thereabouts, Roger Payne, the most celebrated of modern English binders, started a school of his own, and though he only worked for a few years (he died in 1797), the impulse he gave to the art continued for long after his death.

Furniture, Carpets, etc.

In the manufacture of furniture, English makers, during the greater part of the eighteenth century, followed the French school. "In England, we had about the middle of the century a school of carvers, gilders, and ornamenters following the extravagant style of the French. The most prominent name is that of Thomas Chippendale, who worked from the middle till towards the end of the century." 1

Though Chippendale and his contemporaries admittedly drew their inspiration from France, they founded a distinct school of their own, a school whose productions, appreciated in their own days, were disregarded by the following generation, but have now again become fashion-

${ }^{1}$ Pollen, English Furniture, etc., p. 106. 
able, and are much sought after. The first edition of Chippendale's work, the Gentleman and Cabinetmaker's Director, was published in 1754. Robert Adam also had considerable influence on the popular style a little later by his designs-he did not make any furniture-and Sheraton carried on the traditions of the school into the nineteenth century. Heaton ${ }^{1}$ mentions the names of several other contemporary cabinetmakers, and gives abundant illustrations of their works.

Ebony, satinwood, and other tropical woods were now being used for decorative furniture. Mahogany was first brought to London in $1724{ }^{2}$

Carpets until well on in the century were rather a luxury than a necessity. Chambers' Cyclopcedia (1751) defines "carpet" as a covering which might be spread on a table, "or even a passage or floor." From very early times Turkey and Persian carpets had been imported from the Levant. About 1619 Sir Francis Crane started tapestry works at Mortlake, in Surrey, aided by James I.; but, though the Encyclopoedia Britannica speaks of them as making carpets, the very full and elaborate account of the works given in the Victoria County History for Surrey ${ }^{3}$

1 Furniture and Decoration of the Eighteenth Century, J. A. Heaton, 1889.

${ }^{2}$ Holtzapffell's Mechanical Manipulation, vol, i., p. 91.

${ }^{3}$ Vol. ii., p. 354. 
makes no reference to any product other than tapestry. Owing to the failure of the project the works became Crown property. They turned out much fine work under Charles I., languished after the Restoration, and came to an end in 1703. After 1685 some of Colbert's carpet weavers (he had introduced the industry from Persia into France in 1664) came over amongst the other exiles, and some are said to have settled at Wilton and started the industry there.

Defoe (or his Editors) in his Tour, ${ }^{1}$ tells us that the Earl of Pembroke had established some foreign weavers at Wilton, and says "they are already arrived to very great perfection in making tapestry and carpets of all sorts." The writer in the Victoria County History of Worcester, ${ }^{2}$ gives $\mathbf{1 7 4 5}$ as the date for the introduction of the foreign artisans. Before this (1735) carpetmaking had been started at Kidderminster, which had long been noted for its linsey wolseys. The carpet made there was "the flat two-ply reversible carpet, then and now known as Kidderminster." 3

A few years later (1749) John Broom brought over a weaver from Brussels to Kidderminster and started making the "looped-pile fabric." It was in or about 1755 that carpets, in imitation of

1 Edition of 1748, vol. i., p. 339. Defoe died in 1731.

2 Vol. ii., p. 297.

3 Victoria County Histories (Worcester), vol. ii., p. 297. 
those imported from Turkey, were first made at Axminster.

The manufacture of carpets was certainly established in Kilmarnock in Ayrshire before 1777. "The original fabric was the two-ply Scotch or Kidderminster carpet, which still continues to be made largely in Ayrshire." ${ }^{1}$

At Pavenham, in Bedfordshire, there existed a small industry of rush mat-making from the large bulrush (Scirpus lacustris) of the Ouse. This is said to have been in its most prosperous state in the earlier part of the eighteenth century, and to have declined with the increasing use of carpets. $^{2}$

1 Manufactures of the West of Scotland (1876), p. 204.

2 Victoria County Histories (Bedfordshire), vol. ii., p. 124. 


\section{CHAPTER VI}

Brewing - Distilling - Tanning - Candles and Soap-SaltSaltpetre-Gunpowder-Alum-Copperas-Sulphuric AcidSugar-Tobacco.

\section{BREWING.}

By the end of the eighteenth century the ancient practice of brewing beer at home was certainly declining, but until near the end it was universal. Cobbett in 1821 said that forty years before everybody in the country brewed his own beer, and it was stated in evidence before a Parliamentary Committee that about the same time there was not a labourer in a certain Sussex parish who did not do so. ${ }^{1}$

Nevertheless brewing was an established and flourishing industry all over the country before the middle of the century. In the year $\mathbf{1 7 5 4}$ there are said to have been 1042 brewers and 47,405 licensed victuallers, and the amount of beer brewed is given as 3,942,120 barrels of

${ }^{1}$ Curiosities of Ale and Beer. John Bickerdyke (C. H. Cook), 1886. Much of the information which follows is gathered from the pages of this curious volume, but the writer has also to thank Messrs Barclay, Perkins and Co. for some interesting details. 
"strong," and 2,052,771 of "small" beer. In London the number of brewers was 183, and their production, which is not divided, 994,078 barrels. No doubt the majority of the brewers enumerated were working on quite a small scale, but there were wealthy brewers in those days as in our own. The best known of these was Henry Thrale, whose wife, afterwards Mrs Piozzi, is celebrated as the friend of Johnson, and the hostess of the house at Streatham where she entertained Johnson, Burke, Fanny Burney, and most of the wits and celebrities of the time. Thrale and Hester Salusbury were married in 1763, but he was a rich man then, as was his father before him. The brewery was already known in 1710, when it belonged to Edmond Halsey. When Halsey died, it would have passed into the possession of his son-in-law Lord Cobham. But in those days it would have been undignified for a peer to run a brewery, so it was sold for $£ 30,000$ to Halsey's nephew, Ralph Thrale, and from him it eventually passed to his son Henry. It was Thrale's brewery that Johnson described as offering a potentiality of wealth beyond the dreams of avarice, and this statement was partly justified by the fact that Barclay, the Quaker, who bought the brewery on his own behalf, and on behalf of some of his friends, paid $£ 135,000$ for it. Barclay took into partnership Perkins, who had been Thrale's 
manager, and thus was founded the famous brewery of Barclay, Perkins and Co. Before long this firm was at the head of the trade; but in Thrale's time there were three other breweries in London doing a larger business, Calvert's, Whitbread's, and Truman's.

The materials employed seem to have been only malt and hops, though there were at all events attempts made to find substitutes. Mrs Piozzi in her autobiography ${ }^{1}$ tells us that in $\mathbf{1 7 7 2}$ Thrale was nearly ruined by an attempt to make beer without malt or hops, which cost him a large part of his fortune, and most of hers. But if only pure beer was made at that time, there must have been some justification at all events for the notion that illegitimate means were used in the manufacture a little later, to justify Sheridan's gibe, when Samuel Whitbread the Second was complaining at Brooks's that he was being ruined by the tax on malt. Sheridan said, or wrote :-

"The tax on malt's the cause I fear ;

But what has that to do with beer?"

Mr Shadwell, who has made a very careful study of the question, ${ }^{2}$ thinks that at the end of the century adulterants were freely used, and

${ }^{1}$ Autobiography, etc., of Mrs Piozzi, edited by Abraham Hayward, vol. ii., p. 25 (First Edition, 1861).

${ }^{2}$ A. Shadwell, Drink, Temperance and Legislation (1908), p. 208. 
quotes from two writers of 1790 and 1795 lists of ingredients used, or recommended for use, in the brewing of ale and porter. These lists include treacle, liquorice, capsicum, cocculus indicus, ginger, opium, and tobacco, with various other materials.

The percentage of black or "porter" beer which was then brewed in London was much larger than at present, and indeed Thrale's brewery produced little, if any, ale. The percentage of black beer brewed in London and in the rest of the country is now, on the contrary, very small. The process of manufacture does not seem to have varied very much until long after the time in which we are interested. Stability was ensured by a large percentage of hops, which, in these days would be considered excessive. Of course no means were available for refrigeration, and for this reason certain beers were invariably brewed in the winter. It is said that the use of the thermometer in brewing was first suggested by Combrune in his Theory and Practice of Brewing early in the century, and that the saccharometer was introduced by Richardson of Hull in 1784. ${ }^{1} \quad$ In all probability these were the first applications of science to brewing. A considerable amount of export Indian porter was brewed, of a type which is practically now unknown in the East. The firm

1 Yeats' Technical History of Commerce, p. 234. 
of Barclay, Perkins and Co. used to brew a large amount of this beer and send it abroad at the end of the eighteenth century and in the early part of the nineteenth century.

Some of the provincial centres had also at this time established a reputation. Even then the ale of Burton was renowned, and was being exported to Russia, where it was much appreciated by Peter and by Catherine. The Spectator in 1712 spoke of it, and it was later exported in large quantities to India. The firm which afterwards became Allsopps existed at Burton in 1720, and Bass started business in 1777. The beer of other places also had its reputation. Derby, Gloucester, Dorchester, Banbury, Yorkshire, Edinburgh, Glasgow, all had their own specialities, and from some of these towns beer and ale (the meaning of the two terms varied from time to time) was brought up to London or exported. Guinness started in Dublin in 1759, brewing not the stout so well known later, but "Irish brown ale." Porter (the meaning of the term appears to be unknown), then called "Entire," is believed to have been first brewed by one Harwood in London in $\mathbf{1 7 3 0 .}$

The only available materials seem, as above stated, to have been malt and hops. Various queer receipts for making beer survive, but these were only intended for brewing on a domestic scale. There appears no reason to believe that 
any but manual power was employed. At all events, "Bickerdyke" thinks so, and he seems to have made a very extensive research amongst all available records.

Gilbert White ${ }^{1}$ speaks of metheglin (mead or hydromel, a fermented drink made from honey) as if it was a common production, and its occasional manufacture was continued in rural districts down to some time in the last century. Pepys enjoyed it, as he did most good things. Spruce beer, made from the leaves of the spruce fir, is also mentioned, as is treacle beer; but these were never commercial productions.

Cider was made to a considerable extent in the present cider country and elsewhere, but only for domestic consumption.

\section{Distilling.}

The distillation of spirits, "cordials," was carried on in monasteries and country houses from a very early date. There was no excise before 1643. Brandy was also imported from France. But it was not till late in the seventeenth century that the distillation of spirits, practically gin, became an English (principally a London) trade. Once started, it developed with alarming rapidity. "The fatal passion for drink was at once and irrevocably planted in the

${ }^{1}$ Natural History of Selborne, Letter to Daines Barrington, No. xxvii. 
nation." 1 Lecky tells us how the production of British spirits grew from some half-million gallons in 1684 to nearly five and a half millions in 1735, and twenty years later it reached twenty millions. All historians agree as to the disastrous effect on morals of the gin-drinking craze. Legislative measures were powerless to check it, and it was believed that the very existence of the nation was threatened by the growing passion for strong drink. Fielding, in his Enquiry into the Causes of the late Increase of Robbers, etc. (1750), attributes much of the evil he describes to the drunkenness caused by the "Diabolical liquor," the "Poison called gin," and inveighs in the strongest language against the pernicious effects of the new spirit. Hogarth's pictures, too, "Beer-street" and "Ginlane," may be cited as eloquent testimony to the result of replacing the ancient English beverage by the new intoxicant. ${ }^{2}$

1 Lecky, vol. ii., p. 101.

2 Mr Arthur Shadwell devotes a chapter of his book on Drink, Temperance and Legislation, to "Drink in the Past," in England. While he confirms the common opinion that the rage for spiritdrinking, started in the seventeenth, and developed in the eighteenth century, had a most disastrous effect on the morals of the nation, he yet produces much evidence to prove that the English were always addicted to drink. "We may go back century after century, until all records fail, and find the same complaints about the appalling havoc wrought by drink, the bad habits of the people, the superabundance of public-houses and the need for measures of reform, reappearing again and again as something new. The evidence left by writers from age to age is 
The English spirit was made from wort, whereas the imported foreign spirits had been made from wine. The processes of fermentation and distillation seem to have been identical with modern methods. London appears to have been the principal seat of the industry, but there were also large distilleries at Bristol.

Whisky is said to have been first used in Scotland as a beverage in the middle of the seventeenth century, though spirit distilled from malted barley had long previously been known in England and in Scotland, and employed for medicinal purposes. Before the above date, the national drink of Scotland appears to have been beer, which shared with its successor the national title of "barley-bree," a title in later times restricted to whisky alone.

An industry associated with brewing was the manufacture of vinegar. As its name denotes, vinegar was originally made from wine; but the English was malt vinegar, made from wort in which acetic fermentation was set up. In the middle of the century there were large vinegar works at Southwark, Whitechapel, and Wandsworth.

The importation of dried foreign fruits for use sufficiently continuous to show that we have always been a drunken nation, and sufficiently explicit to prove beyond the possibility of denial that in times past the evil has been incomparably greater than anything within modern experience," p. 14.

' Encyclopcedia Britannica, article "Whisky." 
in the manufacture led one of the Southwark vinegar makers to start, about 1750 , a manufacture of British wines, which afterwards developed into an important industry. ${ }^{1}$

\section{Tanning.}

Thorold Rogers tells us that the tanning, or tawing, of leather was in mediæval times a byindustry in most villages, ${ }^{2}$ and probably wherever there were cattle to supply hides, and oak-trees to provide bark, the production of leather on a small scale was carried on. The practice has continued down to our own times, and certainly less than a generation ago the evil-smelling tanyard was common enough in country places. But by the middle of the eighteenth century the trade was already concentrated in certain localities. For several centuries Bermondsey has been a centre of the industry. Writers on Bermondsey, "while declaring their inability to fix a date for the beginnings in Bermondsey and Southwark, hold that its antiquity is remote." "

In 1703 the Bermondsey tanners received from Queen Anne a charter of incorporation, ${ }^{4}$ though this seems to have remained inoperative.

1 Victoria County Histories (Surrey), vol. ii., p. 336.

2 Six Centuries of Work and Wages, vol. i., p. 46.

3 This account of the Bermondsey leather trade is almost entirely taken from the very excellent history of it which appears in the Victoria County History of Surrey.

${ }^{4}$ Wheatley, London Past and Present. 
The days for the control of trade by gilds and by State supervision had passed by, and control by competition, laissez-faire as it is called, was coming in.

It is curious to read the suggestion that Bermondsey originally enjoyed special advantages from its oak-woods, and from the abundance of water-power provided by the numerous tidal streams which flowed through it into the Thames. However this may be as regards the first start, it is more probable that Bermondsey owed its later pre-eminence to the fact that it was close to a large port, whither imported hides were brought; and also that the London slaughterhouses were to a large extent situated in Southwark, on the unfashionable side of the river.

"The story of the terror-stricken creatures who fled from the ravages of the Great Plague in the City of London to the Bermondsey tan pits to find strong medicinal virtues in the nauseous smell may at least be cited as evidence of the fame of these tan pits." 1

It is certain that in 1750 , as in 1910 , Bermondsey was an important centre of the tanning trade. The greater part of the work was doubtless carried out on the spot, though in $1770 \mathrm{we}$ read that Hepburn (the founder of the important firm still bearing the name) used to send out

${ }^{1}$ Victoria County Histories (Surrey), vol. ii., p. 336. 
some hides to "little tanners" in the oakgrowing parts of Sussex.

Northampton was from early times another established seat of the trade, probably because the water-meadows of the Nene provided extensive grazing grounds, whilst the neighbouring woods supplied abundance of oak-bark. ${ }^{1}$ Towards the middle of the century the business is said to have fallen off, doubtless because of the destruction of timber, but later it revived. At this time also the shoe trade was firmly established at Northampton, and it has since greatly developed. At Walsall a good deal of leather was being manufactured for the supply of the saddlery trade which was then lately established there, ${ }^{2}$ and the ancient Leather Hall at Birmingham was the centre of a much older trade of the same sort. At Birmingham, however, the manufacture of leather had diminished, and Hutton, in his history of the city, says that only a single tannery was left in 1781 . In the early part of the century there was a considerable trade in saddlery at Burford, in Oxfordshire, and it is said that Burford saddles had a reputation all over the country.

Tanning was an important industry at Gloucester, with bark furnished from the Forest of Dean; later this migrated to Bristol, no doubt

1 Victoria County Histories (Northampton), vol. ii., p. 310.

2 Timmins, Birmingham, etc., p. 463. 
because of the facilities there for the supply of foreign hides. Wrexham, in the eighteenth century, when it was a town of 3000 inhabitants, had 31 tanneries. In the same century, and apparently before that date, Newcastle carried on an important business in the tanning of Russian hides due to the commerce between that city and the Baltic ports. Later on, the Leeds tanneries came into competition, and the greater part of the trade passed into the hands of the Yorkshire men. ${ }^{1}$ Worcester has had a flourishing glove-making industry since the early part of the eighteenth century. Its origin was possibly connected with the Gloucester and Bristol tanneries, but its continued success is due to the softness of the local water. Woodstock was another centre of the glove trade at the same time.

The bulk of the leather produced in this country was made from English hides, but a contemporary writer ${ }^{2}$ speaks of importations from "Asia, Africa, and America," the best coming from Brazil. Fine qualities of leather were, according to the same authority, also imported from Turkey, Spanish yellow leather, preferred for boots, from Spain, and "morocco leather" from the South of France.

The processes seem to be much the same in

1 Industrial Resources of the Tyne, etc., p. 271.

2 The Art of Tanning, 1780. 
principle as those of the present day. Hides were treated fresh, or were salted if not required for immediate use. As showing the value of salt, reference may be made to the fact that in France an arrangement existed by which the waste salt from the Newfoundland fisheries, which collected in the ships' holds, was used for salting hides, and no tax was levied upon it. Imported hides were dried. The hides were first treated with lime and then tanned with oak-bark in tan-pits. In practice no other tanning material seems to have been employed in this country, though the Art of Tanning gives a long list of plants said to be available for tanning purposes. Sumach is mentioned as being used for the lighter kinds of leather. Calf for bookbinders was tanned with alum, but apparently only in France.

The length of time required for the tanning of hides, a year or more, to a certain extent restricted the business to men who could afford to wait for their money. The tanner, like the village miller, was generally a small capitalist.

The curious connection between tanning and iron-making is illustrated by the fact that the Sheffield tanners in 1750 petitioned against a bill for encouraging the importation of iron from the American Colonies. They urged that if the 
English furnaces and forges were thrown out of work, the coppices would remain uncut, and consequently they would be deprived of the supply of oak-bark required for their business. ${ }^{1}$

\section{Candles and Soap.}

The manufacture of candles was largely a domestic one, at all events in country places, where they were made from any available animal fat. As for many previous centuries, the only available materials were wax and tallow, the former for luxury, the latter for general use. Mrs Elton, in Emma, speaks of the use of "wax candles in the schoolroom" as a sign of the highest gentility.

Spermaceti candles are, however, mentioned in Chambers' Cyclopoedia (1751) as a "modern manufacture," "superior to the finest wax candles in colour and lustre."

Tallow candles were made by dipping ${ }^{2}$ or moulding; in the latter case, moulds of brass, lead, tin, and pewter were employed. Wax candles (which were sometimes conical in shape) were usually made by pouring the melted wax

${ }^{1} \mathrm{H}$. Scrivenor, History of the Iron Trade (1854), Second Edition, p. 74.

${ }^{2} \mathrm{Mr}$ Leopold Field, in the Cantor Lectures which he delivered before the Society of Arts in 1883 (Solid and Liquid Illuminating Agents), gives a very full and interesting account of the process of making "dips." See Journal of the Society of Arts, vol. xxxi., p. 834. 
on the wick, and repeating the process, as each deposited layer cooled. They were finally shaped by rolling them on a board. A method is also described of making wax candles by drawing, after the manner of wire-drawing. Presumably, this only applies to tapers, which are still made in this manner. Night-lights consisted of a "cake of wax set in a silver basin."

Gilbert White has perhaps rescued from oblivion the process of making rushlights. ${ }^{1} \mathrm{He}$ describes how the rush has to be peeled, "so as to leave one regular, narrow, even rib from top to bottom that may support the pith." "When these junci are thus far prepared, they must lie out on the grass to be bleached, and take the dew for some nights, and afterwards be dried in the sun." "Some address is required in dipping these rushes in the scalding fat or grease." The rushes give "a good clear light" at a calculated cost of "five and a half hours of comfortable light for a farthing," whereas a halfpenny candle in the "blowing, open rooms" of a poor man's cottage only lasts two hours. ${ }^{2}$

${ }^{1}$ Natural History of Selborne, Letter No. xxvi., to Daines Barrington, 1775.

${ }^{2}$ The rushlight has survived into recent days, perhaps even to the present time, for Mr Field was able to show to his audience at the Cantor Lectures above referred to, some samples of contemporary rushlights, with the tall cylindrical gauze shade within which they were burnt. 
Soap was also made at home from a lye of wood ashes and grease. The soap boilers who exercised their craft in the towns seem mostly to have worked on a larger scale with much the same materials. The alkali obtained by burning kelp was much used for soap-making. During the whole of the century there were large works in Southwark, and at "Vaux Hall," near London, also at Manchester, Bristol, and no doubt elsewhere.

\section{SALT.}

In mediæval England salt was important rather as a food preservative than as a condiment, as it provided the only known means of keeping meat and fish in an edible condition. The feeding of cattle through the winter was then a costly business, for roots were not cultivated, and artificial food was unknown. As Thorold Rogers points out, ${ }^{1}$ for five or six months in the year the majority of people lived on salted provisions. They had to eat salted meat, or go without meat at all. In Lent everybody had to live on salt fish, an unwholesome diet, which was a fruitful source of disease. The salt, which was always more or less impure, and often dirty, was originally obtained from sea-water all round the coast, evaporated first by solar heat and afterwards by fuel. The

${ }^{1}$ Six Centuries of Work and Wages, vol. ii., p. 95. 
manufacture of salt was among the earliest applications of coal. The process was carried out sometimes in pans or ponds with clay bottoms, but in later years in metal evaporating pans heated by coal. Sussex, Devonshire, Shields, Bristol, Southampton, Prestonpans, all had large salt works. From the southern coasts salt was exported to France, whence, centuries before, when the manufacture had depended on the heat of the sun, it had been imported.

The brine springs at Droitwich were certainly utilised before the early part of the eighteenth century. Thorold Rogers speaks very positively of their not having been known before that date, ${ }^{1}$ but he was evidently mistaken. The writer of the excellent account of the Droitwich works in the Victoria County History of Worcestershive ${ }^{2}$ refers to much earlier records of them, and says that the brine was pumped out and evaporated in pans fired first by wood and afterwards (in 1691) by coal. ${ }^{3}$ In South Shields coal had been used in 1605. In 1725 deeper borings were put down at Droitwich. The salt-bearing strata at Northwich are said to have been

1 Six Centuries of Work and Wages, p. 96.

2 E. B. Pillans, Victoria County Histories (Worcestershire), vol. ii., p. 256.

3 An account of the salt-springs and salt-works at Nantwich, in Cheshire, will be found in the Phil. Trans. (1669), No. liii. (Abridged Edition), vol. i., p. 397. A similar account of the Droitwich (Worcester) Works is given in No. clxii., vol. ii., p. 463. 
discovered in 1670 in the course of boring for coal.

The earliest metal pans in which the brine was evaporated were of lead, and the fuel used was wood. The use of iron pans and the employment of coal as fuel seem to have come in simultaneously. In Cheshire :-

"The ancient way of makeing salt with us, was in lead pans, whereof every wich-house had six of equal gage: and in those they boyled their salt with wood cloven and fitted for ye purpose. This was ye way and usage of makeing salt in this towne till the VIth yeare of King Charles I. (1632). And then it was, that some fancifull persons thought it would be more for their profit to boil their salt in iron pannes (of equall gage with the six leads) with pitte coale, pretending that wood grew scarce."

The "gage" of the "leads" was about 3 or 4 feet square, and 3 or 4 inches deep. The iron pans soon became much larger, in 1748 pans were used in Cheshire, 15 feet by 12, with a depth of 16 inches, while at Shields, pans up to 21 feet by $12 \frac{1}{2}$ were employed. ${ }^{2}$ Later in the

${ }^{1}$ Quoted from Hall's History of Nantwich, by Mr Thomas Ward, in a paper on "The Manufacture of Salt," read before the Society of Arts in 1894 (Journal of the Society of Arts, vol. xliii., p. 82).

${ }^{2}$ Dr Brownrigg's Art of making Common Salt (1748), quoted by $\mathrm{Mr}$ Ward in his above-mentioned paper. 
century the size was still further increased. At the present time the sizes vary from 30 to $\mathbf{1 5 0}$ feet in length, with a width of about 26 feet.

It is to be remembered that the idea of making soda from salt, the foundation of all modern chemical industry, had not yet been realised, though it was perhaps in the air. A little later, Roebuck, the friend of Black and the associate of Watt, who was the founder of the great Carron works in Scotland and the first maker of sulphuric acid on a commercial scale, ruined himself by various speculations, amongst which was one for making soda from salt. ${ }^{1}$

\section{SAltPetre.}

Saltpetre, or nitre (nitrate of potash), was a very important product, since it was a principal ingredient in the manufacture of gunpowder. It was also used in glass-making, and for other purposes. It was first imported from the East, India and Persia. It was made in England and elsewhere in Europe, where it does not occur as a natural product, in "nitre heaps." These nitre heaps were composed of mixtures of animal excrement with wood ashes and lime. The process dates from the time of Elizabeth, when

${ }^{1}$ Smiles, Lives of Boulton and Watt, p. 152; Industrial Biography, p. 135 ; Dict. Nat. Biog., Roebuck. 
a German named Gerard Honrick ${ }^{1}$ discovered to the Queen for a sum of $£ 300$, the secret of making "artificial saltpetre." The heap was watered with urine, and after a sufficient time the material was lixiviated, and the salt crystallised out. The contractors, or gunpowder makers, or commissioners of saltpetre were by various enactments and proclamations authorised to search for and dig out animal excreta, wherever such matters might be found, and for this purpose to enter stables, pigeon-cotes, dwellinghouses, cellars, vaults, etc. Complaints for long were rife at the proceedings of the saltpetre men and the damage they caused. ${ }^{2}$ As time went on, native saltpetre was imported in considerable quantities, and the need for the strenuous search for saltpetre materials passed away; but much was obtained from the nitre heaps at the date with which we are concerned.

\section{GunPowder.}

It is said that gunpowder was first made in

1 In 1561 a patent was granted to "Gerrard Honricke, an Almayne captain, for having taught the making of saltpetre, for £300." In the same year there is a record of Articles of Agreement between Queen Elizabeth and "Gerard Honrick, a German captain who understands the making of saltpetre." Rise and Progress of the British Explosives Industry (1909), p. 210.

${ }^{2}$ A very full account of the early history of the manufacture of gunpowder, and of the methods employed for procuring saltpetre, will be found in the Victoria County Histories (Surrey), vol. ii., pp. 306 et seq. 
England in 1412. For long it was entirely made by hand, but in the fifteenth century there were mills in existence on the Continent. The earliest record of a mill in this country refers to one existing in Edinburgh in 1541, and one was set up at Rotherhithe in 1563. ${ }^{1}$ But it seems fairly certain that the earliest English gunpowder mills of importance were those established at Long Ditton, in Surrey, by George Evelyn (John Evelyn's grandfather) about 1560. Another very important powder factory was that at Chilworth, established about 1654 by the East India Company, or leased by them about that time. This changed hands several times, was flourishing in the middle of the eighteenth century, and is still at work. There were also mills at Dartford, and at Battle, in Sussex, and elsewhere. Defoe tells us that the best powder in the country was made at Battle. The materials, saltpetre, charcoal and sulphur, in the same proportions as in modern black powder, were crushed in mills driven by water-power, pestles being used, and later stones. The Waltham Abbey mills, started early in the seventeenth century, were purchased by Government in 1787. The method of manufacture and

1 O. Guttman, Manufacture of Explosives (1895), vol. i., p. 17. Rise and Progress of the British Explosives Industry (1909), pp. 211, 220, 302, etc. This work contains an elaborate chronology of the early history of gunpowder-making in England, and a list of the makers down to 1800 . 
the nature of the product remained almost unchanged from an early date until quite recent times, and until the introduction of modern powerful explosives.

\section{Alum.}

Alum had at one time been imported from Spain; but long before the date with which we are concerned it had been made in England, and before the beginning of the eighteenth century it was produced here on a large scale, and had become an article of export. ${ }^{1}$ The sources from which it was obtained were the alum shales of Dorset and Devon, and the alum slate (a dark anthracitic shale or schist) of Yorkshire and Lancashire. There are records of early attempts to work the shales of south-western England, and the industry was firmly established at Kimmeridge, and also at Shields and at Whitby. The latter was apparently the chief centre of production. Alum, as we now know it, is a double sulphate of alumina and potash, or ammonia, ${ }^{2}$ but its real constitution was unknown

1 "The first alum works established in England were erected at Guisboro (in the North Riding of Yorkshire) in 1460, by Sir Thomas Challoner, who brought over a workman from France to carry out the then secret process, the monopoly of this trade being in the hands of the Pope."-Industrial Resources of the Tyne, etc., p. 172. The workmen whom Challoner brought over were probably Italians.

2 More correctly, of aluminium and potassium or ammonium. 
until Marggraff, a Dutch chemist (1710-1780), investigated it, and published the result of his researches. Before his time it was believed to be a product of alumina alone. $\mathrm{He}$ pointed out that manufacturers were unable to produce the crystal without the addition of an alkaline solution, and that "at first it had been customary to add a quantity of putrid urine, and that afterwards a solution of carbonate of potash was substituted in its place." ${ }^{1}$ The first-named addition would give ammonia-alum, the second potash-alum.

The old process did not differ very greatly from that still employed. The stone was mixed in heaps with sufficient combustible material and slowly roasted. The heap, after weathering for some time, was lixiviated, and the liquor after partial evaporation was treated either with stale urine or with a solution containing carbonate of potash, usually in the form of soap-boilers' waste or the lye of ashes from burnt seaweed. The result of this was that crystals of sulphate of iron (green vitriol or copperas) and of the double sulphate of alumina (alum) were obtained at different stages of the process. Marggraff's work does not appear to have been known in England, but there is evidence that both processes were employed here in the middle of the century. Chambers, in his Cyclopoedia (1751), says that

1 Encyclopcedia Britannica, article "Alum." 
the liquor is treated with urine, and the specification of Ambrose Newton's Patent (1743, No. 590) refers to the use of "lees made from kilp and slam." ${ }^{1}$ Another specification of 1765 (Holme and others, No. 831) describes a process in which both "stale urine" and "kelp ley" are used.

\section{Copperas.}

Copperas (green vitriol, or sulphate of iron) was made at many places in England, and was a product of considerable importance. It was used in the manufacture of ink, in dyeing, and as a source of sulphuric acid (oil of vitriol). A certain amount of it was, as above mentioned, obtained in the manufacture of alum from shale, but the bulk of it was derived from iron pyrites. The pyrites (sulphide of iron) or "gold stones," as it was termed, was stacked in heaps and allowed to weather. The drainings from the heap were boiled, with some iron added, and evaporated, the sulphate of iron crystallising out. The first factory for the production of copperas is said to have been founded about 1470 by "one Matthew Falconer, a Brabanter" in the Isle of Sheppey. ${ }^{2}$ There were important and oldestablished works at Deptford, Rotherhithe, and

1 "Slam" appears to have been the waste liquor, or refuse, after the extraction of alum from the shale.

${ }^{2}$ Industrial Resources of the Tyne, etc., p. 175. 
Whitstable. About 1754 works were established at Wigan. The Victoria County History of Dorset ${ }^{1}$ quotes from the diary of Celia Fiennes, written in the time of William and Mary, quite a graphic account of a visit to some important copperas works at Brownsea Island, Dorset. The stones are piled in heaps, so that they may be dissolved by the rain. The liquor thus produced is conveyed in pipes to a house in which are set "pans four square and of a pretty depth, at least four yards over." "There are great furnaces under it, keeping the pans boiling." " They place iron spikes in these pans, full of branches, and so as the liquor boils to a candy, it hangs on the branches."

\section{SulPhuric AcID.}

Sulphuric acid, known as "oil" or "spirit" of vitriol," was obtained by two processes, both invented by the alchemist Basil Valentine ${ }^{3}$ in the fifteenth century. In one of these, crystals of sulphate of iron ("copperas"), after some exposure to the air, were distilled in earthen

${ }^{1}$ Vol. ii., p. 330.

2 Vitriol was the name given by the early chemists to certain glassy or vitreous salts: blue vitriol, sulphate of copper; green vitriol, sulphate of iron; white vitriol, sulphate of zinc.

${ }^{3}$ Basil Valentine (probably a pseudonym from basileus and valeo) flourished about the end of the fifteenth century. He was a Benedictine monk in a convent at Erfurt, a celebrated alchemist, and a friend of Paracelsus. 
retorts, the resulting oil of vitriol being condensed in glass or earthenware receivers. A very similar process is still employed at Nordhausen, in Saxony, and Nordhausen, or "fuming" acid, is still an article of commerce. ${ }^{1}$ It differs slightly in its chemical composition from the ordinary modern acid. The second process is the original form of the modern method. In it sulphur was burned under a bell-jar over water, and the acid liquor evaporated. Valentine also burnt a mixture of sulphur, nitre, and antimony sulphide in the same way, and this was an important improvement. About the middle of the eighteenth century, a French chemist found that the antimony was not needed, and considerable amounts of the acid were then made.

Up to the middle of the eighteenth century all, or nearly all, the oil of vitriol made in England was obtained by the distillation of copperas; but in 1740 Ward $^{2}$ introduced its manufacture by the method of burning sulphur and saltpetre.

1 Bloxam's Chemistry (edit. 1875), p. 201 ; (edit. 1903), p. 223.

2 Ward (1685-1761), known as "spot" Ward, from a mark on his face, was a quack doctor who amassed a large fortune by the sale of his remedies. He had an adventurous career, and was a well-known character in his time. In his later life he was popular, and had many patrons, including George II. There are numerous references to him in the literature of the day. A statue of him, by Agostino Carlini, stands at the foot of the staircase in the Society of Arts entrance hall. This statue was presented to the Society in 1793 by Ralph Ward, Ward's grand-nephew and one of his heirs. 
In 1749 he obtained a patent for the process. $\mathrm{He}$ set up works for making the acid, first at Twickenham and afterwards at Richmond. Dr Roebuck improved on the process by substituting lead chambers for the glass receivers, and by this important modification the evolution of the modern method may be said to have been practically completed. Roebuck and his partner, Garbett, first used their improved system in $\mathbf{1 7 4 6}$ at Manchester, and in $\mathbf{1 7 4 9}$ they set up works at Prestonpans, near Edinburgh. This invention revolutionised the industry, greatly lowered the cost of production, and among other applications, enabled the acid to be used, as already mentioned, for bleaching, instead of the sour milk previously employed. ${ }^{1}$

The method used at the present day for the manufacture of the vast quantities of sulphuric acid now required is really only a development of Roebuck's. The principle is the same, though it has been changed by chemical knowledge from an empirical manufacture to a highly scientific process. Iron pyrites (sulphide of iron) has generally replaced the sulphur first used, details have been improved, and the methods rendered more economical ; but the process of manufacture remains in its essential features identical with that of a hundred and fifty years ago.

${ }^{1}$ Brand's Chemistry (edit. 1841), p. 21. See ante, p. 64. 


\section{SUGAR.}

From the seventeenth century the business of sugar-refining was established at Bristol and at Glasgow, whither the sugar was brought from the West Indies. The business of refining sugar is said to have originated in Germany in the sixteenth century, and when it was started here, German and Dutch sugar boilers were brought over. By 1649 there were four important works in Glasgow. A little later the industry was established at Greenock. During the eighteenth century sugar was also refined at Liverpool, and at Warrington in the middle and latter half of the century; a little later it migrated to Manchester. The other important centre where sugar-boiling was carried on at the time was London.

Throughout Europe sugar "continued to be a costly luxury and an article of medicine only, till the increasing use of tea and coffee in the eighteenth century brought it into the list of principal food stuffs." I In 1700 the amount of sugar consumed in Great Britain was 10,000 tons, in 1800, 150,000.

\section{Toвасco.}

As was the case with sugar, the bulk of the tobacco imported into this country was landed at

1 Encyclopadia Britannica, article "Sugar." 
Bristol and Glasgow, and these two cities were then, as they are now, the chief seats of the tobacco industry. The trade was from an early date in the eighteenth century a large one, and the revenue derived from customs-duties was then, as it has since remained, very considerable. The tobacco came from the West Indies and from Virginia. Tobacco was also grown in Southern Europe, but it does not appear that any European tobacco reached this country. For purposes of transit it was rolled up into twists or ropes, and nearly all the tobacco imported seems to have arrived in this form. It was cut up and prepared for chewing or smoking, or was ground up for manufacture into snuff. A very large amount seems to have been made into snuff in London. It does not appear that cigars were made, or much in use in this country.

Pipes were made at various places where suitable clay was to be found. There is evidence of the manufacture of pipes at Northampton, as far back as 1698, ${ }^{1}$ and the pipeclay was not only worked up locally, but was sold to be made into pipes in neighbouring towns. The business appears to have been a flourishing one at Northampton for a long time, and even to have outlasted the exhaustion of the local supply of clay about 1850 .

1 Victoria County Histories (Northampton), vol. ii., p. 308. 


\section{CHAPTER VII}

Shipbuilding and Shipping-Fishing-Agriculture-Minor and Miscellaneous Industries-Patents for Inventions-Banking -Conclusion.

\section{Shipbuilding AND ShipPing.}

Shipbuilding was one of the staple industries of England in 1754. It was prosecuted on a small scale at most of the seaports, and its chief seats were situated on the Thames, the Tyne, and the Humber. Measured by present standards the largest ships of that period were of very small size; warships considerably exceeded merchant ships in dimensions and tonnage, whereas now the relative positions are reversed, and the largest vessels afloat belong to the mercantile marine. In 1745 , the official "Establishment" for ships of the Royal Navy was reconsidered and revised, chiefly because of general complaints that English ships were inferior in armament to French and Spanish ships, carried their guns at too small a height above water, were "crank" under sail, and were structurally weak. About that time it was not 
uncommon to copy ships captured from the French, which fact is, in itself, an open acknowledgment of the inferiority of English designs and designers of warships. In 1747, for example, a 74 gun ship was captured from the French, and about ten years later two English ships were built on her lines and proved very successful. The French and Spaniards were then content with two-decked line of battle ships, while the Royal Navy favoured threedeckers. The first three-decker built under the Establishment of 1745 was the Royal George, laid down in 1746, and not launched until ten years later. Rapid construction was not the rule at that time. Wood was the chief shipbuilding material, and after ships had been put into "frame" they were often left for long periods, in order that the timbers might be "seasoned" before the planking was put on the outside and on the decks. All the operations of shipbuilding were performed by manual power. The largest three-deckers of 1756 were 178 feet long, 51 feet broad, and of 2000 tons burthen. They carried 100 guns as their armament, all these weapons being cast-iron smooth bores, firing spherical shot. The distribution of the armament was as follows:-Twenty-eight 42pounders on the lower deck, at a small height above the water; twenty-eight 24-pounders on the middle deck, twenty-eight 12-pounders on 
the upper deck, sixteen 6-pounders on the quarter-deck and forecastle.

On the 1st of January 1755, the Royal Navy included 134 ships of the line and 162 smaller vessels. Of the ships of the line, 25 carried from 80 to 100 guns per ship, and 109 carried from 50 to 74 guns. The small vessels were armed with 44 guns or a less number per ship. For the year 1754 the Naval Vote was rather less than $£ 380,000$, and the number of seamen and marines provided for was 10,000 . The cost of one of the largest battleships of the Royal Navy, built during the latter half of the eighteenth century, was about $£ 70,000$, exclusive of the cost of guns. Their general features of structure, armament, and equipment differed but little from those of ships which had been built by the Petts at the beginning of the preceding century, and there is reason to believe that the science of shipbuilding was not so well understood as it had been by Phineas Pett and his immediate successors. Experience and "rule of thumb" then prevailed generally amongst English shipbuilders, whose chief merit was the production of well-built vessels, only differing in minor details from those previously constructed.

In the mercantile marine at that period, ships of smaller dimensions sufficed to meet the requirements of trade: the accommodation for shipping in English seaports was very limited 
and not adapted for vessels of large dimensions. Probably the East Indiamen of the latter half of the eighteenth century were amongst the finest and largest merchant vessels afloat. They were well armed and made capable of self-protection against attacks by privateers or regular men-of-war; in addition, they carried passengers and cargoes. In 1772,33 vessels of this class were on service, their aggregate tonnage was rather more than 23,000 tons, and the average tonnage of each ship was only 700 tons.

A further illustration of the small size of ships employed at that date is afforded by the dimensions of vessels used on voyages of discovery to the most distant and unknown parts of the world. Captain Cook started, in 1772, with two vessels drawn from the mercantile fleet, which had previously used Whitby as their home port. The Resolution was of 462 tons, the Endeavour of 366 tons. These tiny vessels were the means of making great discoveries, and were safely navigated in unknown waters. Possibly their small size and moderate draught of water proved advantageous in many circumstances, and facilitated the execution of repairs; but the boldness and skill of Cook and his followers in undertaking oversea voyages of such a nature, in vessels like these, compel our admiration now that ocean-going steamships are in 
existence having burthens of 20,000 to 45,000 tons.

At the commencement of the eighteenth century the total tonnage of English merchant ships was less than 300,000 tons, the total number of ships being about 3300 ; towards the close of that century the totals had risen to more than 16,000 ships, and 1,500,000 tons. This great increase in the English mercantile marine and oversea trade followed upon our success in naval warfare during that century, our principal antagonists being France and Spain. The struggle was long and severe, but its outcome was the establishment of British naval supremacy, with all which the existence and exercise of that supremacy has involved. Of these results, the growth of British shipbuilding, shipping, and commerce is amongst the most important. Lindsey, in his History of Merchant Shipping, sketches the progress made in the dock, bonding, and warehouse systems of our seaports, and records the opinion that without them "England never could have become the chief market of the world." In 1660 the Commercial Dock, on the Surrey side of the Thames, was opened, and at Port Glasgow (on the Clyde) a harbour and graving dock was constructed about the same time; but these docks stood almost alone until 1709, when a floating dock was constructed at Liverpool. Sir Robert Walpole, in 1733, urged the desirability 
of adopting a system of warehousing for imported goods, so that the duties thereon might be collected in a way which would meet the convenience of owners and consignees, while due protection was given to the revenue. Nothing was done, however, to give effect to this suggestion for nearly seventy years, and the great systems of docks and warehouses now existing in all British ports are the product of the last century. It is singular to note the fact that merchants and ship-owners in $\mathbf{1 7 3 3}$ were convinced that they would be ruined if Walpole's proposals were legalised, and it is alleged that he "narrowly escaped falling a sacrifice to the ungovernable rage of the mob which beset the avenues to the House of Commons," before he abandoned the Bill. ${ }^{1}$

\section{Fishing.}

In the middle of the eighteenth century, British fisheries seem to have been by no means flourishing. The old North Sea and Iceland fisheries for cod and ling, to which, in the seventeenth century, many boats from Yarmouth and Lowestoft had made regular voyages once or

1 For the above contribution the writer is indebted to Sir William White, whose kind help he has pleasure in gratefully acknowledging. Sir William has also suggested the following authorities, which may be consulted by those desiring further information:-Derrick's Memoirs of the Royal Navy, 1806; Creuze's Treatise on Naval Architecture, 1840; Lindsey's History of Merchant Shipping, 1874. 
twice every year, had passed into the hands of foreigners, and in 1749 the last solitary boat from Lowestoft went northwards. ${ }^{1}$

The same may be said of the Newfoundland fishery, started by English vessels, but soon abandoned to their foreign rivals. Much of the deep-sea fishing was in the hands of the Dutch, though the French seem to have had a share of it.

The most important fishery was the herring fishery, which has been carried on round the coast from time immemorial. Even this in $\mathbf{1 7 5 0}$ was in a decaying condition, and throughout the century great efforts were made to revive it. Companies with special privileges were formed, and bounties offered by Government. The result was a great increase in the latter part of the century.

Then as now drift nets were used for herring, pilchard, and mackerel. They were made of

${ }^{1}$ Gillingwater's History of Lowestoft (published 1790, and recently re-issued in Lowestoft in an abridged and rather unattractive form) gives a great deal of information about the East Coast fisheries, up to the date of its publication. Fraser, in his Review of the Domestic Fisheries of Great Britain and Ireland (1818), brings the history down to a later date. The Herring and the Herring Fishery, by J. W. De Caux, gives a general account of the subject, and some information is to be found in the handbooks published in connection with the Fisheries Exhibition, 1883, especially in Sir Spencer Walpole's British Fish Trade, and Adam's Fisheries and Fishermen of all Countries. Holdsworth, in his Deep-Sea Fishing, deals occasionally with historical matters. 
hemp, not as now of cotton, and were therefore heavier and consequently not so long. The seine (perhaps the oldest type of net) was used all round the coast. Defoe describes the use of one on the Dorsetshire coast for catching mackerel. Nobody seems to know for certain when trawls were first used. Froude refers to one of the boats, which carried news of the Armada, as a "trawler," but there appears no justification for the use of so specific a title. Brixham is credited with the first employment of the trawl, and it was certainly in use at the time with which we are dealing, though probably most of the bottom fish were caught with lines. ${ }^{1}$

The carriage of fresh fish to London and other towns was a great difficulty. Early in the century some boats were fitted with wells for keeping the fish alive, but the use of this device does not seem to have been common. Proposals were made for sending fish from the south coast to London in carts, with relays of post-horses, at a rate of six miles an hour $;^{2}$ but

${ }^{1}$ Skeat derives trawl from O.F. trauler "to go hither and thither," and refers to the F. trôler "to drag about." He quotes, under date 1706, a definition of "Trawler-men" as "Fishermen who us'd unlawful arts and engines to destroy the fish upon the river Thames." Holdsworth (op.cit., p. 53) says it is not certainly known when or where the invention of the beam-trawl originated, but thinks that the date was some time in the eighteenth century, and the place probably Brixham, but possibly Barking.

${ }^{2}$ Adams' Fisheries and Fishermen of all Countries (Fishery Exhibition Handbooks), p. 48. 
it does not appear whether or not these proposals were carried into effect. Defoe describes the carriage of freshwater fish from the Lincolnshire fens to London in "great buts" filled with water, which was changed at intervals. There could, however, be few species of fish which would survive the ordeal for a time sufficiently long to repay the cost of transporting the great weight of such water-filled barrels.

Large quantities of fish were salted, though salt was dear and hard to come by. Yarmouth and Lowestoft were the headquarters of this business, which was also carried on in the Isle of Man, at Liverpool, in Cornwall (pilchards), and in Scotland.

In the latter part of the seventeenth and the early part of the eighteenth century, the Greenland and Spitzbergen whale fisheries were principally in the hands of the Dutch; but by the middle of the eighteenth century the English whale fishery, aided by bounties, began to revive. It is stated that it was in $\mathbf{1 7 4 9}$ that Scotch ships for the first time took part in this fishing. The pursuit of the sperm whale, or cachalot, is said (Encyclopoedia Britannica) not to have been taken up by British vessels till 1775.

\section{Agriculture.}

Agriculture, though an industry, and a very important one, is not a manufacturing industry, 
and so hardly comes within the scope of this book. As, however, during the early years of its existence, and before the foundation of the Royal Agricultural Society, the Society of Arts was much concerned with agricultural matters, and as, moreover, agriculture was in many ways associated with the changes that occurred in arts and manufactures, it seems desirable to say a few words about its condition at the middle of the eighteenth century. ${ }^{1}$

During that century, very great changes were effected in agriculture in England, but they were for the most part economical and social, rather than scientific or practical. Common lands were enclosed, the "open field" system was to a very large extent abolished, and the land which was formerly held in common amongst a number of proprietors, each of whom was allotted a portion for the growth of his crops, was divided up permanently amongst those who had held perpetual rights of grazing, and temporary rights of tillage over portions of it. The conditions of agriculture were changed with its changing requirements. Large farms took the place of small ones. The change was promoted by the

${ }^{1}$ Gibbon (Chapter II. of the Decline and Fall) remarks that "Agriculture is the foundation of manufactures, since the productions of nature are the materials of art." This conclusion of the great historian was never entirely accurat/, and it is less true now than when he announced it, but it may help to justify the inclusion here of a paragraph upon the subject. 
destruction of the old domestic industries, by which the peasant earned half his livelihood, so that the yeoman, or small land-owner, was compelled either to give up his industrial work and become a day labourer, or to leave his land and to follow his industry into the city, where he became an artisan. The change was very gradual: it may perhaps have started in the seventeenth century; it certainly was evident in the early part of the eighteenth, and by the end of that century it was almost accomplished, though it was not quite complete until well on in the nineteenth. ${ }^{1}$

Many practical improvements were at all events originated in the eighteenth century. The cultivation of roots, clover, and lucerne was introduced, and with this came an improved rotation of crops, which rendered unnecessary the wasteful old practice of leaving the land to lie fallow for a year. Jethro Tull started a new system of husbandry by his introduction of the

${ }^{1}$ Those unfamiliar with this important subject, dealt with here only in a summary and meagre fashion, may be referred to the excellent chapter on "The Agrarian Revolution "in Townsend Warner's Landmarks in English Industrial IIistory, p. 281, to the pages which Lecky devoted to the subject in his History of England in the Eighteenth Century (vol. vi., p. 188), and to many passages scattered through Cunningham's English Industry and Commerce. Arnold Toynbee also allots a chapter of his Industrial Revolution to the "Decay of the Yeomanry," p. 57. The bestknown original authority is Arthur Young, but many references to other sources of information are mentioned by Lecky and by Cunningham. 
drill, invented in 1707 , and described in $1733 .^{1}$ Tull met with the usual treatment meted out to inventors and benefactors of their race, but his ideas had very great influence on farming in this country and abroad.

Bakewell, about 1755, introduced improved methods of breeding sheep and cattle by careful selection. The value of lime for treating certain soils became known, and its use became general about the same time.

\section{Minor and Miscellaneous Industries.}

There were, of course, many minor industries scattered over the country or beginning to establish themselves at centres which offered special facilities for their successful operation. Birmingham was already the home of many of these. The Birmingham gun trade dates back to the end of the seventeenth century. When the demand for the army fell off, the makers turned their attention to fowling-pieces, and they soon found a profitable market in Africa. When this trade commenced, it does not appear to be easy to say, but it was certainly flourishing during the latter part of the eighteenth century. In later years the prices of these weapons varied from $6 \mathrm{~s}$. $6 \mathrm{~d}$. to $13 \mathrm{~s}$. $6 \mathrm{~d}$. apiece, ${ }^{2}$ but these guns were made by machinery. Perhaps those

1 Horse-hoeing Husbandry, 1733.

2 Timmins, Birmingham, etc., p. 420. 
of earlier date were a little dearer; they were probably rather worse.

In the middle of the century nail-making was a flourishing business at Dudley and Bromsgrove, and in the villages round Birmingham. The nails were all made by hand, under the same miserable conditions as long prevailed, female labour being largely employed. Wood screws were also hand-made, the first attempt to use machinery being in 1760, when the Brothers Wyatt brought out apparatus for cutting them, which was partly automatic.

At the beginning of the sixteenth century Chichester is said to have monopolised the needle-making trade of England. Later on, in the middle of that century, we find needles being made and sold in London, and by 1650 the industry was established at Long Crendon, in Buckinghamshire, whence it migrated to Redditch. Here it was firmly established before the date with which we are concerned, as was also the manufacture of fish-hooks, a business always now associated with needle-making. The needles were at first all made by hand, no apparatus more elaborate than a grindstone being employed. ${ }^{1}$ In 1700 a horse-mill is said to have been employed for pointing and scouring the needles, and a little later water-power was brought into use for the same purpose. The needles were ${ }^{1}$ Timmins, Birmingham, etc., p. 198. 
clumsily made and badly tempered, and being soft they bent, so that they required occasional straightening.

In the middle of the century Rylands started pin-making at Birmingham. Till very much later the pins were of the old-fashioned sort still remembered by older folk, the heads of which were made of brass wire twisted round the shank. Pins were also made in other parts of the country. Gloucester records state that the manufacture was established there in 1626, and was prosperous about 1750 . Pins for lacemaking were made at Northampton.

Button-making was an important industry at Birmingham, the materials used being principally steel, brass, iron, and wood. Sheffield also made steel buttons.

Lime-burning was carried on all over the country wherever there was chalk or limestone. It is recorded that nearly every large farm in Sussex possessed a lime-kiln for burning chalk. Charcoal burning, even now carried on on a small scale, was an important industry. All round the coast seaweed was burnt to obtain alkali.

Fuller's earth was obtained in Surrey and elsewhere in some quantity. It was of sufficient importance for its export to be prohibited.

The making of gun-flints, an industry which was in its fullest vigour in the eighteenth century, 
and continued to flourish till the invention of the percussion cap in 1816, could hardly have been expected to survive to the present day, yet it appears from inquiries recently made that there is a small trade done in gun-flints and "strike-alights" at Brandon, in Suffolk. There are still some of the old families of knappers who carry on the business, and may be seen at work practising what must surely be the oldest handicraft known to man, the fashioning of flint implements. $^{1}$

The origin of the straw plait industry appears to be doubtful, but it was certainly established at Luton in 1764, and at Dunstable in 1768. In later years it was much encouraged by the Society of Arts.

The manufacture of hats was of some importance in London, and was also carried on from an early date (1546) in Newcastle. ${ }^{2}$ An article in Chambers' Cyclopcedia (1751) gives a very

${ }^{1}$ A full and extremely interesting account of the manufacture is given by S. B. J. Skertchley, in one of the Memoirs of the Geological Survey, published in 1879. This account describes minutely, and with abundant illustration, the whole process of "flaking" and "knapping" flint, and is the standard authority on the subject. At that time (1879), a large number of gun-flints were being made, as well as "strike-a-lights." It seems probable that the demand for the latter may still preserve this interesting old industry from destruction. Incidentally the author throws a great deal of light on the manufacture of prehistoric flint implements. Few vanishing industries have been fortunate enough to find so accurate and painstaking a historian.

${ }^{2}$ Industrial Resources of the Tyme, etc., p. 244. 
full account of the process of hat-making, though it is not very easy for one who is not an expert hatter to follow all the details. "The finest, and those best valued, are made of the pure hair of an amphibious animal called the castor or beaver, frequent in Canada and other provinces of North America;" the hair of the rabbit, hare, camel, etc., was also used. The hair, after cleansing, was felted together, and the hat shaped by moulding and pressing." It is added that "Hats make a very considerable article in commerce." The industry was at all events considerable enough for the London hatters to get an Act passed in 1732 prohibiting the making of hats in America. According to Cunningham," "This American industry appears to have been the only Colonial manufacture that developed enough to compete with the mother country."

\section{Patents for Inventions.}

It was during the eighteenth century that the system of granting patents for inventions was really developed. From early times it had been the practice of the sovereign to grant monopolies for manufacturing or trading in various articles, and this was indeed the recognised method of securing the establishment of new trades and

${ }^{1}$ A very good account of the old process of hat-making is given in the Encyclopoedia Britannica, article "Hats."

${ }^{2}$ Growth of English Industry and Commerce, p. 587. 
industries. The earliest recorded is of the time of Edward III. Unfortunately the grants were not restricted to new manufactures, and Queen Elizabeth granted such patents or monopolies so freely that the practice became a grave abuse, ${ }^{1}$ and gave rise to numerous and bitter complaints both in the House of Commons and out of it. ${ }^{2}$ But it was not until the next reign that a remedy was applied, and in 1623 the Statute of Monopolies was passed. This transferred from the sovereign to Parliament the power of granting monopolies; but there was a clause excepting "any manner of new manufactures within this realm." ${ }^{3}$ Upon this clause our whole patent system has been built up, chiefly by the courts

1 Encyclopoedia Britannica, article "Monopoly."

${ }^{2} \mathrm{Mr}$ E. W. Hulme, in an article on English Glass-making, in the Antiquary, vol. xxx., p. 210, puts the other side of the case rather strongly. He maintains that even Elizabeth's grants tended on the whole to the encouragement of industry :-

"Already in the brief interval which elapsed between the first Monopoly patent for soap in 1561, and the year 1567, these grants had been effectual in establishing the copper industry at Keswick, the manufacture of alum and copperas in the Isle of Wight, that of brass and iron wire at Tintern, besides introducing a host of improved machines and processes in milling, mine drainage, harbour dredging, and the extraction of oils, saltpetre, etc." It is difficult to accept his view wholly, and the question is one well deserving further investigation, but the practical results are well known and beyond dispute.

3 This clause (sect. vi.) fixed the term of the grant at fourteen years, and this term has been continued to the present day. A previous clause (sect. v.) excepted similar grants then existing, the term of which was twenty-one years. 
of law, but also by certain statutes. The system thus evolved continued with very little change until our own time, when the practice was reformed by the Act of 1852 and subsequent Acts, though even by these there has been no change in the old doctrine first stated in the Statute of Monopolies, and since elaborated by the vast mass of legal decisions which have been given upon it. Even after the Statute of Monopolies, many patents were granted for subjects which were not, in the modern sense of the word, inventions; and the novelty was confined to this kingdom, or rather to England, Scotland and Ireland having for long their own patent laws.

At first a very large proportion of the socalled new inventions were introductions from other countries; and the privilege was readily granted to anyone who could show that his manufacture was not in practice in England, the consideration for the award being the practice of the invention, not, as is now the case, the divulging of the novel discovery for the benefit of the public. In the case of the great majority of the earlier grants, no specification or description of the invention was recorded. Webster ${ }^{1}$ tells us that the first specification bears the date of XI. Anne. This appears to have been No. 393, A.D. 1713 - a grant to Aaron Hill for his invention of making oil from beech nuts.

${ }^{1}$ Law and Practice of Letters Patent for Inventions, 1841, p. 6. 
According to Webster, the principle that the patentee's secret should be fully disclosed, and that this should be a condition of the validity of the grant, was not recognised until some time in Queen Anne's reign, the exact date being doubtful. But gradually a proviso got to be introduced into all patent grants that the patentee was to enrol within a certain term a full description of his invention. This stipulation appears in many grants from about 1725, and a little later in all. The ultimate result was that the validity of the grant of letters patent came to depend on the sufficiency of the patentee's description, and on the accuracy of the statements contained or implied in it, first as to the novelty of the invention and next as to its being proper "subject matter" for the grant, that is to say, whether it came within the definition of a "new manufacture" as settled by the decisions of the courts.

Thus the specification enrolled by the patentee, not the original grant by the Crown, became the instrument on which the inventor had to depend for the maintenance of his rights. The letters patent themselves, originally all-important, degenerated into mere evidence of the date of registration of the inventor's claim.

This change in the system and practice of Patent Law, commencing, as above stated, at the end of the first quarter of the eighteenth century, was completed by the middle of the century, 
though its full effect was not realised until the great mass of mechanical inventions during the latter half of the century necessitated the accurate registration of those inventions, and a careful discrimination of the claims of those who originated them. ${ }^{1}$

\section{BANKING.}

No account of the condition of industry at any time could be complete without some reference to the state of banking at that time, since banking is one of the most important factors in the promotion of all industries and commerce. It would not be too much to say, at all events so far as internal trade was concerned, that up to the middle of the eighteenth century, English traders were practically without banking facilities. "The business of Banking was not introduced into England till the seventeenth century, when it began to be undertaken by goldsmiths in London, who appear to have borrowed it from Holland." ${ }^{2}$ The Bank of England had been founded in 1694 at the instance of William Paterson, who was also a year later the founder of the Bank of Scotland. The Bank of Ireland was not established until 1785. There were other and older banks in

${ }_{1}$ Mr E. W. Hulme has discussed this whole question at considerable length and with much research in two articles in the Law Quarterly Review, July 1897 and January 1900.

2 Encyclopoedia Britannica, article "Banking." 
London, but up to about 1750 there were only three provincial banks in England, at Nottingham, Bristol, and Hull, and two banks (besides the Bank of Scotland) in Scotland. All these banks issued notes, and as soon as the supply of notes was sufficient, and their use recognised, they provided one of the greatest facilities for the development of internal trade. But it was evidently long before their usefulness came to be appreciated, and in the meantime all transactions had to be in specie. The chapmen and traders who went from one town to another were obliged to take with them a considerable amount of coin, and there are many stories as to the devices employed by such persons for concealing their money, either on their own persons or among their packages of merchandise.

$\sqrt{1 \mathrm{At}}$ the end of the century the number of local banks rapidly multiplied, and with disastrous results, for many of them were badly managed and had insufficient capital, so that in the bad times from 1792 to 1797 some of them suspended payment, or failed altogether. This rapid increase in the number of banks shows how useful they were, and how much their notes were appreciated. Up to 1759 the Bank of England did not issue notes for a less amount than $£ 20$. In that year it commenced the issue of $£ 10$ notes. But the country banks were in the habit of issuing notes for lower amounts, 
even (before the practice was prohibited by legislation in 1755) for amounts below a pound. It was the small note which was found convenient. The $\& 1$ note was often preferred to gold.

The profits of bankers were generally derived from receiving and keeping one person's money at one rate of interest, and lending it to another person at a higher rate; but they also derived large profits from their note issue, and they consequently endeavoured to keep their notes in circulation as long as possible, and many devices were employed for the purpose. Considerable efforts were made to extend the circulation of the notes to distant spots, from which the difficulties of communication prevented their immediate return. For instance Scotch bankers were in the habit of encouraging Highland drovers to take all the money they required in the form of local notes, which they circulated at various points along their routes to the south, so that it was often a long time before the note found its way back to the original bank of issue.

We shall more easily realise the service which these early note issues rendered to trade and commerce, if we remember that the device of payment by cheque is of quite modern origin, and does not appear to have been employed until the beginning of the nineteenth century. ${ }^{1}$

${ }^{1}$ According to the New English Dictionary, the word cheque 
No doubt from the earliest days of banking a debtor whose moneys were in charge of a banker would discharge his liabilities by giving his creditor a draft on that banker, but there seems no reason to believe that the practice was other than exceptional in ordinary business transactions until long after the date with which we are specially concerned.

\section{Conclusion}

It is hopeless to expect that this sketch of the industrial state of the kingdom at the epoch selected can be complete, but it may probably be claimed that the omissions and oversights are not important enough to affect the general purpose of the work, the provision of material for a comparison of the conditions of industry before, during, and after that period in which the greatest industrial changes were made in the shortest time.

At the beginning of the eighteenth century, English industry was carried on under mediæval conditions. At the end of it the conditions were almost those which now prevail. In the days

originally meant counterfoil, a device used to check fraud or forgery. Thence it came to be applied to any draft or form having a counterfoil. The first reference to the use of the word in its modern sense is dated 1803, "cheques, as they are called, or drafts to bearer on some banker." 
of Queen Anne, England was a pastoral country exporting corn and raw materials, and as regards manufacturing industries, less advanced than her Continental contemporaries. The means of communication were little better if at all than those of Tudor times: the roads were bad; there were no canals; but little use was made of the rivers. There were few industries, and those domestic. Here and there were localities in which infant industries were showing signs of organisation, principally in places in which immigrant aliens had settled, driven from their own lands by foolish religious persecutions, and bringing with them knowledge and skill (to say nothing of character and courage) which their ignorant persecutors were too bigoted to appreciate. Science was in the dilettante stage, the amusement of a few clever souls who loved knowledge, and could withstand ridicule. Though it was valued for such practical results as it gave, it was not advanced enough to render any real help to manufactures, and if a few methods did exist for the extraction of chemical products, they were all either the result of the crudest empiricism, or were based on the experiments of mediæval alchemists. None of the forces of Nature had been subdued to the service of man. The power of the wind, and that of flowing water, had been occasionally utilised in a rough and imperfect fashion, but, for the most part, the 
only power which man for centuries had had at his disposal, was his own strength and that of his fellow-animals.

In a few years all this was changed. By the time of the last of the four Georges, England was the leading manufacturing country in the world. She had excellent roads and a good transport service; she had almost completed an admirable series of canals and had improved her riverine communications. The crowded cities of the land were full of factories, in which all sorts of goods were produced by machinery. Chemistry had taken its place among the sciences, and the discoveries of its votaries (not alone in England) were being utilised for the manufacture of new products and the simplification of old processes. The steam-engine had been completed and set to give motion to all sorts of machinery, while the machines it drove had been rendered available for many tasks, which, during the previous centuries, human fingers alone had been deemed capable of executing.

In later days the advance has been more rapid, and the consequent effect upon humanity has been greater. But the advance during the last century has been along the lines laid down by the workers of the century before. The steam-engine has been perfected, and other agents than steam have been utilised for the provision of motive power. Mechanical power has been 
applied to transport on land and water. The crude devices of the older mechanicians have been developed and improved. The applications of machinery have been multiplied a hundredfold. New natural forces have been investigated and applied. Science has been utilised in every branch of industry. The progress had been enormous, the change hard to estimate. Still, when all has been said, it has been development, not revolution, and the changes of the eighteenth century were revolutionary and organic.

Whether such alterations as are here indicated have been on the whole beneficial to humanity is a question too large for consideration here. They have been produced at the cost of an infinite amount of human suffering. They have certainly resulted in much human happiness and much human misery. Students of social and political economy will decide for themselves to which side the balance inclines, and no doubt in coming to a decision they will be greatly aided by their preconceived political and social views. The present writer may content himself with the humbler task of collecting and recording what he believes to be the facts. 



\section{INDEX}

Aberavon, copper-smelting at, 82 Aberdeen, cloth-making in, 43 ; linen manufacture in, 62

Academy, The Royal, 4

Acts of Parliament, offering reward for discovery of Northwest Passage, 9 ; turnpike, 29 , 31 ; highway, 31 ; improving river communications, 35 ; for protecting woollen industry, 50 ; prohibiting use of calico, 51; prohibiting import of printed calico, 56 ; permitting importation of American iron, 80 ; prohibiting export of coal, 95; for emancipating Scotch colliers, 99 ; incorporating glass manufacturers, 105 ; offering prize for chronometer, 119; prohibiting import of American hats, 172 ; statute of monopolies, 68,174

Adam, Robert, 126

Adam, the Brothers, 6

Adams, Fisheries and Fishermen, $164 n, 165 n$

Adulteration of beer, 131

Africa, colonies in, 13

Agriculture, relative importance of, 16 ; improvement in, 32 ; associated with domestic industry, 40, 60, 168; general conditions of, 166

Aire and Calder navigation, 35

Aix-la-Chapelle, Treaty of, 1,12

Ale, 132, 133

Alien immigrants, 17 ; cotton, 49 ; linen in Ireland, 63 ; silk, 66,
67 ; ribbon-making, 69 ; Irish poplin, 70; sail-cloth, 71; brass, 77; copper, 82; glass, $101 \mathrm{n}$; mirrors, 106 ; paper, 121 ; carpets, 127 ; saltpetre, 148 ; alum, $150 n$; copperas, 152 ; sugar, 156

Alkali for glass-making, 102 ; for soap-making, 144; for alum-making, 151 ; from seaweed, 102, 144, 151, 171

Allsopps' brewery, 133

Alum, 150

Alva, persecutions of. See Alien Immigrants

America, silk in, 70 ; iron-making in, 79 ; tobacco from, 157 ; exports of pottery to, 112 ; hats made in, 173

Anderson's History of Commerce, $56 n$

Animal power, 19, 22, 53, 84, 97, 170

Antigua, 12

Arcot, 13

Arkwright's spinning machinery, 54

Armorial services of porcelain, 113

Arnold, J., watchmaker, 119

Arts, Society of, 1, 4, 18, 21, $33 n$, $57 n, 81 n, 87 n, 89,94 n, 95 n$, $96 n, 103 n, 120 n, 142 n, 146 n$, $154 n, 172$

Ashburnham, iron furnace at, 74

Astbury, potter, 111

Automata, 120

Automatic machinery, 28

Axminster carpets, 127 
BaHamas, the, 12

Baines, History of Cotton Trade, $34 n, 50,68 n$

Bakewell, stock-raising, 169

Banbury, brewing at, 133

Banking, 177

Bank-notes, 178

Banks, Sir Joseph, 8

Barbados, 12

Barclay, Perkins \& Co., 131, 133

Bargarran thread, 63

Barilla, 102

Barry, James, 4

Baskerville, 122, 123, 124

Bass's brewery, 133

Battersea enamels, 117

"Battery-works," 83, 106

Battle, gunpowder made at, 149

Beckmann's History of Inventions, $21 n$

Bedfordshire, lace in, 65

Belfast, linen manufactures of, 63

Bell-founding, 86

Bell-metal, 86

Bellows, furnace. See Blast

Benson's patent for grinding flints, 112

Bermondsey, tanning in, 137

Bermudas, the, 12

Berthollet uses chlorine for bleaching, 64

Bickerdyke, Curiosities of Alo and Beer, $129 n$

Bilston, making tin-plate in, 86

Birdwood, Sir G., Relics of East India Co., 113

Birmingham, brass-making in, 83,84 ; bell-founding in, 87 ; pewter in, 89 ; glass in, 101 ; leather trade of, 139; gun trade, 169; nail-making in, 170 ; button-making in, 171 ; pin-making in, 171

Bischoff, History of the Woollen Manufacture, 39, 44 n

Black, Joseph, 8

Blaeu's printing-press, 124

Blankets, making, 46

Blast for iron and other furnaces, $21,75,76,77,87,88$

Blasting in mines, 100

B le aching of textiles, 64
Block-making machinery, 28

Blowing engines. S S B Blast

Bloxam's Chemistry, $154 n$

Bolsover, Sheffield plate, 94

Bookbinding, 125

Bottles, glass, 106

Boulton, Matthew, 53 n

Bow, porcelain works at, 114, 115, 117

Boydell, John, 5

Boyle, Robert, 8

Bradford (Yorks.), cloth-making in, 43

Bradford-on-Avon, cloth-making in, 43

Bradley, James, 10

Bramah's slide-rest, 27

Brandon, flint-knappers of, 172

Brand's Chemistry, $155 n$

Brandy, 134

Brass-foundry, John Darby's, 77

Brass-making, 77, 81, 83 ; manufactures, 83,84

Brewing, 129 ; materials used in, 131,133 ; adulterants used in, 131 ; methods of, 132

Bridgewater canals, 36

Bridport, manufacture of ropes, cordage, etc., at, 71

Brindley, 31, 36, 69

Bristol, blankets made at, 46 ; sail-cloth made in, 71 ; brassfounding in, 77 ; copper-smelting in, 81 ; brass-works at, 83 , 84; pottery made at, 111 ; exports of pottery from, 112 ; porcelain in, 115 ; distilleries in, 136 ; tanneries of, 140 ; soapboiling in, 144 ; salt-works in, 145 ; sugar-boiling in, 156 ; tobacco in, 157

Britannia ware, 89

Britten, E. J., Clock and Watch Makers, $119 n$

Bromsgrove, nail-making at, 170

Bronze, 82, 86

Broom, J., introduces " Brussels" carpets, 127

Brough, B. H., Mining, etc., $95 n$

Brown, W., method of screening coal, 97 
Brownrigg, Art of Making Salt, $146 n$

Brownsea Island, copperas works in, 153

Brunel's block-making machinery, 28

Buchanan on mill-work, $28 n$

Buckinghamshire, lace in, 65

Bulmer, printer, 124

Burford saddles, 139

Burke, 2, 32

Burton, W., on pottery, 110, 116 ; Hist. English Earthenware, $110 \mathrm{n}$; (and Hobson) Marks on Pottery, ttc., $115 n$; Porcelain, $116 n$

Burton breweries, 133

Butler, Samuel, 9 n

Button-making, 171

Calrco, Indian, 49, 50, 51, 56

Calico-printing, 56

California, 11

Calvert's brewery, 131

Cambric, French, 51

Cambridgeshire, lace in, 65

Canada, 11

Canals, 34

Candles, 142

Canterbury, bell cast in, 86 ; silkweaving in, 66

Canvas, manufacture of, 72

Caps, knitted, 48, 49

Carbonate of soda, manufacture of, 102,147

Cardan's smoke-jack, $21 n$

Carpets, 126

Carriages, 32, $33 n$

Carron Iron-works, 77

Cartwright's power-loom, 54

Caslon, type-founder, 123

Caughley, potteries at, 117

Causton and Keane, Chartered Companies, $11 n$

Cavendish, Henry, 8

Cementation process of brassmaking, 83

Century of Inventions, Marquis of Worcester's, $24 n$

Cider, 134

Chambers, Sir W., 6

Chambers' Cyclopaedia, 58 n
Champion, W., brass works at Bristol, 84

Charcoal, making iron with, 73

Charcoal-burning, 171

Charley, W. T., Linen, $64 n$

Cheadle, brass works at, 83

Chelsea porcelain, 115, 117

Cheques, 179

Chichester, needle-making in, 170

Chiddingford, glass at, $101 n$

Chilworth gunpowder mills, 149

China. See Porcelain

China-clay, 112, 114, 115, 116

Chippendale, T., 125

Chronometer, Harrison's, 10, 119

Church, Prof., on pottery, 110

Clanny's safety lamp, 97

Clayton, Messrs, calico-printing, 57

Clive, 13

Clock-making, 28, 118

Cloth-making. See Wool

Coachbuilding, $33 n$

Coaches, mail, 29, 33

Coal, conveyance of, $31,33,34$, 94 ; making iron with, 75 ; smelting lead with, 88 ; first use of, 94 ; applications of, 95 ; screening, 97; used in making salt, 146

Coalbrookdale, iron made at, 76

Coal-mines, animal power in, 22 ; early, 94; depth of shafts in, 95 ; fire-damp in, 96 ; ventilating, 96 ; lighting, 96 ; safetylamp for, 97 ; pumping, 25, 97 ; haulage in, 97 ; servile labour in, 98

Coalport potteries, 117

Cobb, B. F., Silk, $66 n$

Cobbett on home-brewed beer, 129

Cochran-Patrick, records of mining, etc., $90 n$

Cod fisheries, 163

Coke, 76, 88

Coke ovens, $76 n$

Coking coal, 76

Coles, Cowper, Sheffield Plate, $94 n$

Collieries. See Coal-mines

Collins, 3 
Colonies, condition of, in 1754, 10; silk in, 70: exports of pottery to, 112 ; tobacco from, 157. See also America

Colours used for stained glass, 107

Combrune, Theory, etc., of Brewing, 132

Cook, Capt., 9, 11, 161

Cooke, C., Automata, Old and New, $120 n$

Cookworthy discovers kaolin, 115

Copeland's pottery works, 117

Copley medal, 9, 10

Copper and brass, 80

Copper mining, 81 ; smelting, 81

Copperas, 151, 152

Cordage, manufacture of, 70

Cornwall, lace in, 65 ; coppersmelting in, 81 ; fisheries, 166

Cort, invention of puddling and grooved rolls, 78

Cosway, 5

Cotton manufacture, 49 ; mixed fabrics of, 49,60 ; Indian fabrics of, 49 ; spinning and weaving by hand, 51 ; use of machinery for, $48,51,53,54$

Coventry, ribbon making in, 69

Crane, Sir F., tapestry works, 126

Creuze, Naval Architecture, $163 n$

Cripps, W. J., Old English Plate, $91 n$

Crompton's mule, 54

Crouch ware, 111

Crown glass, 105

Crushing ores, mills for, 21

Crystal glass, 103

Cumberland, copper mines in, 81

Cunningham, English Industry and Commerce, $11 n, 31,41 n$, 44, 55, $68 n, 168 n, 173$; Alien Emigrants, $66 n$

Cutlers' Company, the, 79

Dance, George (the elder), 6

Dance, George (the younger), 7

Darby, Abraham, smelts iron with coal, 76

Darby, Abraham (the younger), casts iron pots, 77

Darby, John, brass-foundry in Bristol, 77
Dartford gunpowder mills, 149

Darwin, Erasmus, Botanic Garden, 55

Davey on Newcomen engine, $25 n$

Davy's safety lamp, 97

Day, Lewis, on stained glass, 108

Dean, forest of, iron in, 73 ; tin plate in, 85

De Caux, The Herring, $164 n$

Defoe's Tour, 29, 43, 50, 127, 165, 166

Delft ware, 111

Deptford, copperas-works in, 152

Derby, framework knitting in, 47 ; silk mill at, 68 ; porcelain works, 115, 117; brewing at, 133

Derbyshire, lead-smelting in, 87

Derrick, Memoirs of the Navy, $163 n$

Devonshire, cloth-weaving in, 43 ; lace in, 65 ; alum shales of, 150

Dirck, Life of Marquis of Worcester, $24 n$

Distilling, early history of, 134

Docks and harbours, 162

Dollond, J., 10

Domestic industries, 40, 50, 55, $60,64,65,71,168$

Dominica, 12

Dorchester, brewing at, 133

Dorsetshire, alum shales of, 150 ; lace in, 65

Dossie, Annals of Agriculture, $21 n$

Droitwich salt works, 145

Dublin, manufacture of poplin in, 70 ; brewing in, 133

Dud Dudley, Metallum Martis, $76 n$

Dudley, nail-making at, 170

Dundee, cloth-making in, 43; linen manufacture in, 62

Dunstable, straw-plaiting at, 172

Dupleix, 13

Durham, iron in, 73

Dwight, John, 110

Dyeing, methods and materials, 58

Dyeing textiles, 56

Dyer, John, The Fleece, 44 
Earlom, R., 5

East India Company, 13 ; imports of porcelain by, 112

East Indiamen, 161

Eastlake's Gothic Revival, 7 n

Edict of Nantes, Revocation of. See Alien immigrants

Edinburgh, brewing at, 133 ; gunpowder made in, 149

Electric telegraph, Gray's, 10

Elers, the Brothers, 111

Ellicott's gridiron pendulum, 119

Encyclopédie, Diderot's, description of slide-rest, 27 ; papermaking in England, 121

England, Bank of, 177

Espinasse, Lancashire Worthies, $52 n$

Evelyn, G., gunpowder mills, 147

Excise, 134

Explosions in coal-mines, 96

Falconer, M., starts alum-making, 152

Felkin, History of Lace Manufacture, $47 n$

Fergusson, Modern Styles of Architecture, $6 n, 7 n$

Field, L., Illuminating Agents, $142 n$

Fielding, Henry, 3 ; on drunkenness, 135

Fielding, Sir J., $51 n$

Fiennes, Celia, describes copperas works, 153

File-cutting machine, Wyatt's, 28

Fire-damp, 96

Fire-gilding, 94

Fish, carriage of, 165

Fish-hooks, making, 170

Fishing, 163

Fishing nets, manufacture of, 71

Flax. See Linen

Flaxman, 5, 118

Flesce, The, by John Dyer, 44

Flint, calcined, for pottery, 111 ; grinding by water wheel, 112

Flint glass, 103, 104

Flints, " knapping," 172

Florida, 11

Fly-shuttle, Kay's, 51; used in Scotland, 61
Focq's planing-machine, 27

Fourdrinier's paper machine, 123

Framework knitters, Company of, 48

Framework knitting, 47

Francis, Major Grant, coppersmelting in Wales, 81

Franklin, 8, 10, 70

Fraser, Domestic Fisheries, otc., $164 n$

Fuller's earth, 171

Fulling mills, 20, 42, 46, 49

Furnace bellows. See Blast

Furnaces for iron-making, 74, 75, 76 ; for smelting lead, 87

Furniture, 125

Fusees, machine for cutting, 28

Fustians, 49

Gainsborovgh, 5

Galloway, History of Coal Mining, 19, $95 n, 98 n$; Steam Engine, etc., $23 n$

Gardiner, S., on pewter, 89

Gateshead, pottery made in, 112 , 117

Georgia, 11

Gibbon, 3; Decline and Fall, 30, 167

Gibbs, J., 7

Gillingwater, History of Lowestoft, $164 n$

Gin, 134

Glasgow, cloth-making in, 43 ; calico-printing in, 57; linen manufacture in, $60,61,62$; thread manufacture in, 63; brewing at, 133 ; sugar-boiling in, 156 ; tobacco in, 157

Glass, early, 101 ; materials for, 101 ; flint, 103; lead, 103; crown, 103; exports of, 104 ; blowing, 105; sheet, 105; plate, 105; mirrors, 105; bottles, 106 ; stained and painted, 107; colouring matters for, 107 ; cutting, 107

Glass-ware, 104

Glazes for pottery, 111

Gloucester, bell-founding in, 87 ; brewing at, 133 ; pin-making in, 171 
Gloucestershire, silk manufacture in, 69 ; copper-smelting in, 81

Gold, mining and metallurgy of, 90

Gold Coast, 13

Gold plate, 91 ; destruction of, 92,93

Goldsmith, Oliver, 3

Goods, conveyance of, 29, 31, 33, $34,35,36,37,94,100,165$

Graham's mercurial pendulum, 119

Gray, Stephen, 10

Gray, Thomas, 2

Green, J. R., History of English People, 16, $16 n, 17$

Green, Valentine, 5

Greenock, sugar-boiling in, 156

Grignon, T., clock-maker, 120 n

Grinding corn, mills for, 21

Guest, History of Cotton Manufacture, 50 n

Guiana, 12

Guinness's brewery, 133

Gumley's glass gallery, $106 n$

Gun-flints, manufacture of, 171

Gun-metal, 86

Gunpowder, 147, 148

Gun trade, Birmingham, 169

Guttman, O., Explosives, 149 n

Hall, History of Nantwich, $146 n$

Halley, 8, 9

Halsey, E., brewer, 130

Hancock, J., Sheffield plate, 94

Hansard's Typographia, 123

Hargreaves' jenny, 54

Harrison's chronometer, 10, 119

Hartshorne, Old English Glasses, $101 n, 103 n, 107$

Harwich, imports of pottery, 111

Harwood, first brewer of porter, 133

Hats, manufacture of, 172

Haulage in coal-mines, 97

Hayward, A., Autobiography of Mrs Piozzi, 131 n

Heath, J., 5

Heaton, J. A., Furniture of Eightesnth Century, $126 n$
Heaton, N., on stained glass, $103 n$

Hemp, 70

Hepburn, tanner, 138

Herring, R., Paper and Papermaking, $121 n$

Herring fishing, 164

Hertford, first paper-mill at, 121

Hertfordshire, lace in, 65

Hindley's screw-cutting lathe, 28

Hindostan. See India

Hogarth, 4, 5,

Holdsworth, Deep Sea Fishing, $164 n$

Holtzapffel, Mechanical Manipulation, 126

Home, John, 3, 9 n

Home-brewed beer, 129

Home uses sulphuric acid for bleaching, 64

Homer, H., Enquiry into Public Roads, 31

Honduras, 12

Honrick, G., patent for saltpetre, 148

Hooke, Robert, 8

Horseback, travelling on, 29, $30 n, 31$

Horse power. See Animal Power

Horses, pack, 31, 33, 34, 37

Houghton's sa wmill, 21

Hudson's Bay, 11

Huguenot immigrants. See Alien Immigrants

Hull, imports of pottery, 111 ; exports of pottery, 112 ; bank in, 178

Hulme, E. W., industry in the Middle Ages, $15 n$; early English glass, $101 \mathrm{n}$; monopolies, $174 n$; patents, $177 n$

Humber, shipbuilding in, 158

Hume, 3

Hunter's Hallamshire, 79, $94 n$

Huntsman, B., casts steel, 78

Huyghens, 25

InDIA, state of, in 1754, 13; calico, etc., from, $49,50,51,56$; porcelain from, 113 ; export of beer to, 132 
Industrial Revolution, the, 15, 17, $18,168$.

Ink, writing, 59, 152 ; printer's, 124

Innes, C., Early Scotch History, 98

Inventions, patents for, 173

Ipswich, sail-cloth made at, 71

Ireland, linen manufacture of, 60,63 ; woollen manufactures of, 63 ; kelp-burning in, 102 ; bank of, 177

Iron, tilt hammers used in making, 20 ; made with charcoal, 72 ; made with coal, 76 ; puddling, 78 ; rolling, 21, 78, 86 ; in America, 79, 141

Iron ware, etc., making, 77, 79

Jamaica, 12

Jenkins, Rhys, on early papermaking, $122 n$

Jenny, spinning, 54

Jernegan, silver plate designed by, 92

Jervais, painted windows by, 109

Johnson, Samuel, 2, 31, 44 n, 130

Jones, Inigo, 6

KANDLER, silversmith, 92

Kaolin, 112, 114, 115, 116

Kay, John, invention of flyshuttle, 51

Kelp, 102, 144, 151, 171

Kent, iron works of, 74

Kidderminster carpets, 127

Kilmarnock, knitted bonnets, 49 ; carpet-making at, 128

Kimmeridge alum works, 150

Knitting, hand, 46, 49

Knitting-frame, Lee's, 47

Lacemaking, 64 ; machines for, 48 ; pins for, 171 ; thread for, 63,65

Lally, 13

Lamberhurst, iron furnace at, $74 n$

Lambeth, pottery made at, 111

Lancashire, cotton in, 49 ; coppersmelting in, 81 ; alum slate, 150

Languedoc Canal, 35

La Salle, 11
Lathe, the, 26 ; used in making pottery, 112

Lead glaze for pottery, 111

Lead in glass-making, 103

Lead, mining, 81 ; metallurgy, 87 ; artistic uses of, 88 ; alloy, 89 ; desilverising, 90

Leadhills, gold and silver mines at, 90

Leather. SeB Tanning

Lecky, History of England in the Eighteenth Century, $2 n, 16 n$, $50,51,135,168 n$

Leeds, cloth - making in, 43; pottery made at, 117 ; tanneries of, 140

Leicester, framework knitting in, 47

Liberty, L., on pewter, 89

Lime-burning, 171

Limehouse, sawmill in, 21

Lindsay, W. L., on gold in Scotland, 91

Lindsay, Hist. Merchant Shipping, 162, $163 n$

Linen manufacture, 60 ; mixed fabrics of, 49,60 ; domestic industry, 60 ; bleaching, 64

Lisburn, linen manufacture in, 63

Literature, state of, in 1754, 2

Liverpool, river communications, 35 ; imports cotton, 55 ; pottery made at, 111 ; pottery exported from, 112 ; porcelain made in, 115 ; sugar-boiling in, 156 ; fisheries, 166

Locks, canal, 35

Lombe, Sir T., silk-spinning machinery, 22, 67

London, sawmill in, 20 ; framework knitting in, 47 ; calicoprinting in, 56 ; lace in, 65 ; silk-weaving in, 66; making pewter in, 89; coal in, 94; glass made in, 101 ; pottery exported from, 112; breweries in, 130, 133 ; distilleries in, 136; sugar-boiling in, 156 ; needles in, 170 ; hat-making in, 172

London Bridge, water wheels at, 19

Long, History of Jamaica, $12 n$ 
Long Crendon, needle-making in, 170

Long Ditton, gunpowder mills, 149

Longton Hall, porcelain works, 115

Looking-glasses, 105

Louisiana, 11

Lowestoft porcelain works, 115 , 117 ; fisheries, 163, 166

Lowther, Sir J., steel mill, 97

Luton, straw plaiting at, 172

MacArdeli, J., 5

Macaulay's History, 29, 35

Macclesfield, silk mill at, 69

Machine tools, 26

Mackworth, Sir Humphrey, 19

Maidstone, paper-making at, 122

Mail-coaches, 33

Man, Isle of, fisheries, 166

Manchester, river communications, 35; and Worsley canal, 36 ; manufactures of, 37 ; cotton manufacture in, 55 ; soap-boiling in, 144; sulphuric acid works at, 155 ; sugar-boiling in, 156

Manganese in glass-making, 102

Mansell, Sir R., glass works, 103

Marggraff, investigations in alum, 151

Mary, Queen, love of Indian coloured calicoes, $56 n$

Mat-making, 128

Maudslay's slide-rest, 27

May, Sir T. Erskine, Constitutional History of England, 98 n

Mead, 134

Meikleham, Anecdotes of Steam Engine, $23 n$; History of Steam Engine, 23 n

Mercantile marine, 160, 162

Merchandise, conveyance of, 29 , $31,33,34,35,36,37,94,100$, 165

Metcalf, John, the blind roadmaker, 31

Meteyard's Life of Wodgwood, 34, $110 n, 112 n$

Metheglin, 134
Miller, Hugh, slavery of Scotch colliers, 99; My Schools, etc., $99 n$

Mills, fulling, 28, 42, 46, 49

Mills, gunpowder, 149

Mills, water. See Water Power

Mills, wind. See Wind-mills

Miners' Friend, The, 23, $24 n$

Mines, coal. See Coal-mines

Mirrors, glass, 105

Monkhouse, Cosmo, on engraving, 5

Monopolies, grants of, 174; statute of, 174

Montcalm, 11

Montserrat, 12

Mordants used in dyeing, 59

Morland, Sir S., 23

Morley, H., Life of Cardan, $21 n$

Morley, J., Life of Burke, 32 n

Mortlake, tapestry works at, 126

Motive power, 18

Moulds for candles, 142 ; for pottery, 111, 112 ; for "wove" paper, 122

Moxon, on the lathe, 27

Mudge. T., watchmaker, 119

Mule, Crompton's, 54

Muslin, Indian, 49, 50; made at Paisley, 56

Musselburgh coal-mines, 99

NaIl-Making, 170

Nantwich salt works, $145 n$

Navy establishment, 158, 160

Neath, copper-smelting at, 82 ; silver working at, 91

Needle-making, 170

Nesbitt, Glass Vessels, otc., $103 n$

Nevis, 12

Newcastle, rope-making in, 70 ; glass in, 101, 103, 106 ; tanning in, 140; hat-making in, 172

Newcomen's engine, 17, 19, 24, $25,26,97$

Newfoundland, 11 ; fisheries, 164

Newton, Sir Isaac, 8

Nitre. Sbe Saltpetre

Nollekens, 5

Norfolk, cloth-weaving in, 43

Northampton, lace in, 65 ; leather trade of, 139 ; tobacco pipes 
made at, 157 ; pin-making in, 171

Northumberland, copper mines in, 81

North-west Passage, 9

Northwich salt works, 145

Nottingham, framework knitting in, 47,48 ; bank in, 178

Nova Scotia, 11

Ores, mills for crushing, 21

Oppenheim's patent for glassmaking, 104

Oxfordshire, lace in, 65

Pack-honses, 31, 33, 34, 37

Painted glass. See Stained Glass Paisley, cotton manufacture in, 56 ; linen manufacture in, 61 , 62 ; thread manufacture in, 63 ; silk weaving in, 69

Palliser, Mrs, History of Lace, $64 n$

Palmer's mail coaches, 33

Paper-making, pulping rags for, 21 ; early history of, 121 ; improvements in, 122

Papin, 23

Patents for inventions, 173

Paterson, W., 177

Pattinson's desilverising process, $90 n$

Paul and Wyatt's spinning machine, $22,45 n, 53$

Pavenham, mat-making at, 128

Payne, J., hot-air engine, 21

Payne, Roger, 125

Peckett, stained glass by, 109

Peel, Robert, calico-printing, 57

Pendulum, mercurial, 11.9 ; gridiron, 119

Pepys, 134

Percussion cap, 172

Percy, Dr, Iron and Steel, $75 n$, $76 n$; iron-making, 76 ; steelmaking, 78 ; copper-smelting, 81 ; Metallurgy, $81 n$; brassmaking, 84 ; lead, 87

Percy's Reliques, 3

Pettus, Sir J., 87 n

Petty, Sir W., on dyeing, 58

Pewter, 88; tableware of, 113
Pianofortes made in London, 84

Pin-making, 171

Piozzi, Mrs, 130

Pipes, tobacco, 157

Pitt, William (Lord Chatham), 1

Plaids, Scotch, 43

Planing-machine, Focq's, 27

Plassy, 13

Plate, gold and silver, 91 ; destruction of, 92, 93

Plate-glass, 105

Plumier, on turning, 26

Plymouth porcelain works, 115

Pollen, J. H., English Furniture, 125; Gold and Silver Smiths' Work, $91 n$

Pondicherry, 13

Pope, 2

Poplin, manufacture of, 69

Porcelain, early history, 112 ; French, Dresden, Meissen, etc., 114 ; oriental, 112; varieties of, 116

Porter, 132, 133

Potter's wheel, improved, 112

Pottery, early, in England, 109 ; imported, 111 ; improvements in manufacture, 112 ; exports of, 112,118 ; decorating by transfers, 116; development of manufacture, 117

Power, animal. See Animal Power

Power loom, the, 54

Preston, calico-printing in, 57

Prestonpans, salt works in, 145 ; sulphuric acid works at, 155

Prices, the, stained glass by, 109

Priestley, Joseph, 8

Printing, 123; type, 123 ; ink, 124 ; press, 124

Printing and dyeing textiles, 56

Prussian blue, 59

Pumping mines, 25, 88, 97

Quarries, 100

Quebec, 11

Queen's ware, 116, 118

Radcliffe, Origin of Power Weaving, 41, $55 n$

Rags for paper-making, pulping, $21,121,123$ 
Railways, origin of, 100

Rankine on the steam-engine, 19

Redditch, needle-making in, 170

Reynolds, Sir Joshua, 4 ; stained glass by, 108, 109

Ribbed stockings, frame for knitting, 47

Ribbon-making, 69

Richardson, Samuel, 3

Richardson introduces use of saccharometer, 132

Richmond (Surrey), calico-printing in, 56 ; sulphuric acid made at, 155

Ripon, lace in, 65

Rivers, transport by, 35

Roads, 28; Roman, compared with English, 30

Roebuck, Dr, iron works at Carron, 77; experiments at making soda from salt, 147 ; improves sulphuric acid manufacture, 155

Rogers, Thorold, Six Centuries of Work and Wages, $16 n, 40,137$

Rolling iron plate, 86

Rolls for iron, Cort's, 78

Rolls for making tin-plate, 21

Romney, 4

Rope-making, 70

Rotherhithe, copperas works in, 152

Roubiliac, 6

Rovenzon, Treatise of Metallica, $75 n$

Royal Academy, 4

Royal Society, 8, 9, 10, 23, 58, $119,122,145 n$

Rushlights, 143

Rylands starts pin-making in Birmingham, 171

Rysbrach, 6

Saccilarometer, 132

Sadler \& Green, transfer process for decorating pottery, 116

Safety lamp, 97

Sail-cloth, manufacture of, 71

St Helena, 13

St Helens, glass-works at, 105

St Kitts, 12

St Lucia, 12
St Paul's Cathedral, iron railings of, 74

St Vincent, 12

Salt, value of, 141 ; early uses of, 144 ; from sea-water, 144 ; from brine-springs, 145 ; use of coal in making, 145 ; pans for making, 146; soda from, 102, 147

Salt glaze for pottery, 111

Salting hides, 141

Saltpetre, used in making glass, 102 ; manufacture of, 147 ; used in making gunpowder, 147, 149

Saltworkers, slavery of Scotch, 98 Samuel Bros., Wool and Woollen Manufacture, $40 n$

Savery's engine, 23, 24

Sawmills, 20

Scheemakers, 6

Scotland, roads in, 31 ; clothmaking in, 43 ; cotton manufacture in, 56 ; Treaty of Union, 60 ; linen manufacture in, 60 ; linen bleaching in, 64 ; silver in, 90 ; gold in, 90 ; collieries in, 94 ; slavery of colliers in, 98; kelp-burning in, 102 ; whisky in, 136 ; beer in, 136 ; fisheries of, 166 ; bank of, 177

Screening coal, 97

Screw-making by machinery, 170

Scrivenor, History of Iron Trade, $80 n, 142 n$

Seaweed, 102, 144, 171

Seeley, Sir J. R., Expansion of England, $13 n$

Serfs in Scotch collieries, 98

Sewing-thread, 62

Shadwell, A., Drink, otc., $131 n$; $135 n$

Shaw, Christian, improves manufacture of thread, 62

Sheet-glass, 105

Sheffield, iron- and steel-making in, 78,79 ; button-making in, 171

Sheffield plate, 94

Shenstone, 3

Sheppey, Isle of, alum works in, 152

Sheraton, 126

Sherborne, silk manufacture at, 68 
Shields, salt works in, 145 ; alum works at, 150

Shipbuilding, 158 ; books of reference, $163 n$

Shipley's Drawing Academy, 5

Ships, armament of, 160 ; sizes of, $158,159,160,161$

Shropshire, iron in, 73

Silk, frame for knitting, 48 ; spinning by machine, 52,66 ; early history of manufacture, 66 ; weaving, 69 ; mixed fabric of, 69 ; grown in colonies, 70

Silver, mining and metallurgy of, 90

Silver plate, 91 ; destruction of, 92,93

Silvering mirrors, 106

Skertchley, description of flintknapping, $172 n$

Slavery in Scotch collieries, 98

Slide-rest, the, 27

Slip-decorated ware, 111

Slitting mills, 21

Smalt, $59 n$

Smiles, Industrial Biography, 20, $27,73,75 n, 147$; Lives of the Engineers, 30, 31, 34, 36, 37, 69, 147 ; Men of Invention, 68

Smith, Adam, 3

Smoke-jack, 21

Smollett, 3

Smuggling lace, 66 ; wool, $44 n$

Soap-making, 144

Somersetshire, lace in, 65

Southampton, salt works in, 145

Southwark, vinegar works in, 136 ; tanning in, 137; British wine-making in, 137; soapboiling in, 144

Specification of letters patent, 176

Spedding's steel mill, 96 ; system of mine ventilation, 96

Spermaceti candles, 142

Spielman, paper-making, 121

Spinning by machinery, 17, 53 ; by hand, 42 ; cotton, 50,52 ; wool, 52 ; jenny, 54 ; silk, 52 , 66 ; hemp, 72

Spinning metals, 89

Spitalfields, silk-weaving in, 66

Spode, Josiah, potter, 117
Sprat, History of Royal Society, 58

Springs, carriage, 32

Spruce beer, 134

Staffordshire, making tin-plate in, 86

Stage coaches, 29, 33

Stained glass, 107

Stamps for pottery, 111

Stanhope, Earl printing, press, 124

Steam-engine, origin of, 23 ; Newcomen's, 17, 19, 24, 25, 26, 97 ; Savery's, 23, 24; Marquis of Worcester's, 24 ; Papin's, 23 ; Hooke's, 25; Watt's, 8, 17, 26, 31 ; applied to drive textile machinery, 55 ; used for blowing furnaces, 76, 77

Steel, casting, 78

Steel mill, 96

Steele's Lover, 106 n

Stephenson's safety lamp, 97

Sterne, 3

Stewarton, knitting at, 49

Stocking-loom, Lee's, 47

Stoke-upon-Trent, pottery made in, 112,117

Stone-mining, 100

Straw-plait industry, 172

Stroud, cloth-making in, 43

Strutt, J., 47

Stuart, History of Steam Engine, $23 \mathrm{n}$; Anecdotes of Steam Engine, $23 n$

Sturtevant, Treatise of Metallica, $75 n, 76 n$

Suffolk, cloth-weaving in, 43; sail-cloth made in, 71

Sugar, 156

Sulphuric acid, 153

Surajah Dowlah, 13

Surrey, fuller's earth in, 171

Sussex, iron works of, 73, 74; tanning in, 139; salt works in, 145; home-brewed beer in, 129 ; lime-burning in, 171

Swansea, copper-smelting in, 81 ; potteries in, 117

Swift, 2

TABLEWARE, silver, 92; pewter, 89,113 ; china, 113

Tallow candles, 142 
Tanning, early history of, 137 ; processes of, 140 ; materials used in, 141 ; connection with iron manufacture, 141

Tate's paper-mill, 121

Thames, shipbuilding in, 158

Thermometer first used in brewing, 132

Thorpe, 5

Thrale, H., 130

Thread, sewing, 62

“ Throstle," Arkwright's, 54

Throwing silk, apparatus for, 52 , 66

'Thrupp, G. A., Lectures on Coachbuilding, $33 n$

Thurston, History of Steam Engine, $23 n$

Tidal power, 19

Tile-work, Saxon, 109

Tilt hammers, 20

Tin, mining, 81,85 ; plate, 85 ; exports, 85 ; alloys, 86

Tobacco, 156

Tobacco pipes, manufacture of, 157

Tobago, 12

Tompion, 118

Toynbee, Arnold, Industrial Revolution, $16 n, 168 n$

Tram-roads, origin of, 100

Transfer process for decorating pottery, 116

Trawls, 165

Trinidad, 12

Truman's brewery, 131

Tull, J., horse drill, 168

Turnpike Acts, 29, 31

Tyne, shipbuilding in, 158

Type, printing, 123

Twickenham, sulphuric acid works at, 155

Ulster, linen trade of, 63

Valentine, Basil, makes sulphuric acid, 153

Van Linge, stained glass by, 108

Vaucanson, 120

Vauxhall, soap works in, 144

Ventilation of mines, 96
Vertue, silver plate designed by, 92

Vinegar manufacture, 136

Virgin Islands, 12

Vitriol. See Sulphuric Acid

Von Kempelen, 120

WADE, General, roads of, 31

Wakefield, cloth-making in, 43

Wales, lace in, 65 ; silver in, 90

Wall, Dr, porcelain works, 117

Walpole, Horace, 3, 113

Walpole, Sir Robert, 1, 162

Walpole, Sir S., British Fish Trade, $164 n$

Walsall, leather trade of, 139

Waltham Abbey gunpowder mills, 149

Wandsworth, vinegar works in, 136

Ward, Joshua, sets up sulphuric acid works, 155

Ward, Thomas, on salt manufacture, $146 n$

Warehouses, bonded, 163

Warner, T., English Industrial History, $168 n$

Warrington, sugar-boiling in, 156

Waste heat of furnaces, utilising, 21

Watchmaking, 118

Water frame, Arkwright's, 54

Water power, uses of, grinding corn, 19 ; pumping, 19 ; crushing ores, 21 ; rolling tin-plate, 21 ; working bellows, 21 ; pulping rags, 21; working slitting mills, 21; drawing wire, 21, 84; working tilt hammers, 20 ; driving fulling mills, 20,42 ; driving spinning machinery, 45, 54, 67; blowing iron furnaces, 75,76 ; in Sheffield trades, 79; blowing lead furnaces, 87,88 ; grinding flint, 112; in Bermondsey, 138 ; making needles, 170

Watt, James, 8, 17, 26, 31

Wax candles, 142

Weaver, L., uses of lead, 88

Weaving wool, 40 ; blankets, 46 ; cotton, 50 , 52 ; fustians, 50 ; 
silk, 66 ; ribbon, 69 ; hemp, 71 ; carpets, 127 ; by machinery, 17,54

Webster, T., Patents for Inventions, $175 n$

Wedgwood, 116, 118

West, B., 4

West Indian tobacco, 157 ; sugar, 156

West Indies, 10, 12; pottery exported to, 112

Weymouth, sail-cloth made in, 71

Whale fishery, 166

Whatman, paper-making, 122

Wheat, export of, 16

Wheatley, London Past and Present, $137 n$

Wheel-cutting machine, 28

Whisky, 136

Whitbread's brewery, 131

Whitby, alum works at, 150

White, Gilbert, 8, 134, 143

Whitechapel, vinegar works in, 136

Whitehaven, collieries in, 95

Whitstable, copperas works in, 153

Wigan, copperas works in, 153

Willis, Prof., on machine tools, 26

Wills, T., Explosions in Coal Mines, $95 n, 96 n$

Wilton, J., 6

Wilton carpets, 127

Wiltshire, lace in, 65

Wind-furnaces, 73, 75, 87

Wind-mills, uses of, grinding corn, 19 ; pumping, 19 ; draining mines, 19 ; in collieries, 20 ; driving sawmill, 21; various applications, 21

Wine, British, making, 137

Wire drawing, 21, 84

Witney blankets, 46

Wolfe, 11
Wolverhampton, making tinplate in, 86

Woodcroft, Brief Biographies, stc., $52 n, 53 n$

Wool, industry of, 39 ; hand spinning and weaving, 41, 52; fulling mills, $20,42,46,49$; principal localities of, 43 ; Dyer's poem on, 44; smuggling, $44 n$; knitting, 46 ; machinery used in, 46, 47 ; acts for protecting, 50

Woollett, 5

Worcester, cloth-weaving in, 43 ; porcelain works, 115, 117 ; glove-making, 140

Worcester, Marquis of, 24

Worcestershire, iron in, 73

Worsley and Manchester Canal, 36

“Wove" paper, 122

Wren, Sir Christopher, 6

Wrexhain, tanning in, 140

Wrotham pottery made at, 111

Wyatt and Paul's spinning machine, 22, $45 n, 53$

Wyatt Brothers' screw-making machine, 170

Wyatt's file-cutting machine, 28

YALDEN, 19

Yarmouth, imports of pottery, 111 ; fisheries, 163, 166

Yarranton, improvements in tinplate, 85

Yeats, Technical History of Commerce, $132 n$

Yorkshire, iron in, 73 ; coppersmelting in, 81 ; breweries, 133 ; alum slate, 150

Young, Arthur, 3, 29, $168 n$

ZiNc, reduction of, 81, 83 ; alloy, 82,83 
PRINTED BY

OLIVER AND BOYD RUINBURGH 


\section{A SELECTION FROM}

\section{Mr MURRAY'S LIST}

A CRITICAL EXAMINATION OF SOCIALISM. By W. H. Mallock. Cheap Edition. Crown 8vo. Paper

Covers. 1s. net.

"Mr Mallock's brilliant critical examination."-Times.

"We have not met with a more able statement of the points at issue, and everyone should read the book, whether he is an opponent or a defender of Socialistic theories. . . . By this book Mr Mallock resumes the position he held twenty years ago as one of the shrewdest thinkers and most lucid writers in our midst."-Sheffield Independent.

THE PEOPLE'S PROGRESS : A Study of the Facts of National Wealth, and some Answers to Socialists. By Frank Ireson, B.A. Demy 8vo. 2s. 6d.

"As a text-book of political economy, Mr Ireson's little volume will be cordially welcomed. As a scathing exposure of Fabian absurdities it has few if any equals."-Globe.

THE BASIS OF SOCIAL RELATIONS: A Study in Ethnic Psychology. By Daniel G. Brinton. Edited by Livingston Farrand. Demy 8vo. 8s. net.

\section{THE PRINCIPLES AND METHODS OF TAXATION.}

By G. Armitage Smith, M.A., Principal of the Birkbeck College. Crown 8vo. Cheap Edition. 2s. 6d. net.

The object of this work is to present in a concise and simple form an account of the British system of taxation and the principles on which it is based, together with some of the leading historical facts in its evolution.

"A treatise as useful as it is modest, which discusses in a broad and lucid way the principles and history and difficulties of taxation." -St James's Gazette. 
COLLECTIVISM: A Study of some of the Leading Social Questions of the Day. By Paul Leroy-Beaulieu, Member of the Instilute, and Professor of the College of France. Abridged and Translated by Sir Anthur Clay, Bart. Demy 8vo. 10s. 6d. net.

"It is a searching exposure of the shallowness and sophistry of the leading Socialistic writers of our time, and could it only be plainly made known to the crowds who unthinkingly believe and applaud the Socialistic agitators in our streets, it would serve a still more useful purpose. . . Many difficulties which the Socialists have not detected are explained with much force and lucidity in M. Beaulieu's book, which it is to be hoped will be carefully read by all who have it in their power to influence the working classes of this country."-Yorkshire Post.

LOCAL AND CENTRAL GOVERNMENT : A Comparative Study of England, France, Prussia, and the United States. By Percy Ashley, M.A., Lincoln College, Oxford; Lecturer at the London School of Economics and Political Science in the University of London; Author of "Modern Tariff History." Demy 8vo. 10 s. $6 \mathrm{~d}$. net.

THE MANUFACTURE OF PAUPERS: A Protest and a Policy. By Sir Arthur Clay, Bart., Sir William Chance, Bart., Sir Edward Brabrook, W. A. Bailward, Miss K. V. Bannatyne, Thomas Mackay, Colonel E. Montefiore, and Mrs E. T. OGiLvy. With an Introduction by J. St Loe Strachey. Large Crown 8 vo. 2 s. 6 d. net.

" These papers form a strong and emphatic condemnation of the 'dole' system of government, which is becoming more and more characteristic of modern England, and which is viewed with so much concern by all those who value manly independence and individual intelligence. The book should be carefully studied by those sentimental but unwise people who continually cry aloud for the State to do this or that, without pausing to recollect that every new step in that direction is helping to destroy all that has made the England of the past. "The articles on the feeding of school children are especially vigorous."-Sheffield Daily Telegraph.

MUNICIPAL OWNERShIP. By Major Leonard Darwin, Author of "Municipal Trade" and "Bimetallism." Crown 8vo. 2s. 6d. net.

Four Lectures delivered at Harvard University, discussing in a popular manner the advantages and disadvantages of Municipal Ownership, as Municipal Trade is called in the United States. 
THE BRITISH TRADF BOOK. First Issue, covering the 25 years (1880-1904), and showing the Course of Trade; Second Issue, covering the 26 years (1880-1905), and showing the Course of Trade. By John Holt Schooling. With numerous Tables, each containing several sections of British or of International Trade. Numerous Diagrams. 10s. 6d. net each issue.

This is the only book that shows the course of trade in an intelligible and compendious form.

"This is going to be one of the great books of reference, universally recognised as such, a storehouse of sifted and ordered facts, indispensable to anyone taking part in current economic controversies."Guardian.

"No thoughtful and patriotic Englishman, whatever his political creed, will refuse gratitude to $\mathrm{Mr}$ Schooling for this most opportune work. The excellence of Mr Schooling's method is clear at a first glance amongst the tables."-Daily Chronicle.

\section{WORKS BY SIR HENRY S. MAINE}

ANCIENT LAW. Its Connection with the Early History of Society, and its Relation to Modern Ideas. With Introduction and Notes by Sir Frederick Pollock, Bart. Demy 8vo. 5s. net.

ANCIENT LAW. Demy 8vo. 2s.6d. net.

INTRODUCTION AND NOTES TO MAINE'S ANCIENT LAW. By Sir Frederick Pollock, Bart. Demy 8vo. 2s. 6 d. net.

VILLAGE COMMUNITIES IN THE FAST AND WEST. Six Lectures delivered at Oxford. Demy 8vo. $9 \mathrm{~s}$.

LECTURE ON THE EARLY HISTORY OF INSTITUTIONS. Demy 8vo. 9s.

DISSERTATIONS ON FARLY LAW AND CUSTOM. Demy 8vo. 9s.

POPULAR GOVERNMENT. Four Essays. Cheap Edition. Large Crown 8vo. 2s. 6d. net.

INTERNATIONAL LAW. The Whewell Lectures, delivered at Cambridge in 1887. Demy 8vo. 7s.6d. 
MODERN TARIFF HISTORY. Showing the Origin and Growth of Tariffs in Germany, France, and the United States. By Percy Ashley, M.A. Demy 8vo. 10s. 6d. net.

"A careful, fair, and accurate review of the modern fiscal history of three countries."-Times.

THE SERVICE OF THE STATE: Four Lectures on the Political Teaching of T. H. Green. By J. H. Muirhead, M.D., LL.D., Professor of Philosophy in the University of Birmingham. Demy 8vo. 3s. 6d. net.

OVER-SEA BRITAIN: A Descriptive Record of the Geography, the Historical, Ethnological, and Political Development, and the Economic Resources of the Empire.

THE NEARER EMPIRE. The Mediterranean, British Africa, and British America. By E. F. Knrght, Author of "Where Three Empires Meet," "Small Boat Sailing," etc. With 9 Coloured Maps. Crown 8vo. 6 s. net.

" In this book Mr Knight has turned his travel sketches into a gazetteer without losing the brilliance of the one or failing to obtain the fulness and accuracy of the other. It is a wonderful literary feat! Anyone taking up the volume without knowing its instructive character, would read to the end for pleasure; and yet it is a book which no newspaper office nor anyone who requires works of reference can possibly do without."-Morning Post.

AUSTRIA-HUNGARY. By Geoffrey Drage, Author of "Russian Affairs." With Maps. Medium 8vo. 2ls. net.

"Mr Drage has aimed, he tells us in the preface, at making a permanent contribution to the subject; and after a critical and exhaustive examination of the work, we can aver that he has succeeded. . . The standard work of the time on AustriaHungary."-Giobe.

THE TRIBE, AND INTERTRIBAL RELATIONS IN AUSTRALIA. By Gerald C. Wheeler, B.A., late Martin White Student in Sociology in the University of London. With a Prefatory Note by EDward A. Westermarck, Ph.D., Professor of Sociology at the University of London. Demy 8vo. 3s. 6d. net. 
INDIAN PROBLEMS. By S. M. Mitra. With an Introduction by Sir George Birdwood, K.C.I.E., C.S.I., LL.D. Large Crown 8vo. 7s. 6d. net.

"A useful and candid contribution to the discussion of many of the perplexing issues which engross the attention of Indian administrators. Sir George Birdwood calls Mr Mitra's pages 'earnest, laboured, accurate, elementary, and weighty,' praise which is not too high even from such an authority . . . such a work is specially welcome."-Times.

WESTERN CULTURE IN FASTERN LANDS: A Comparison of the Methods adopted by England and Russia in the Middle East. By Arminius Vambéry, C.V.O., Author of "Travels in Central Asia," "History of Bokhara," etc. Medium 8vo. 12s. net.

"It is always a pleasure to read anything published by Professor Vamberry, and it is more especially so when he deals with the great problems of the influence of Europe upon Asia, and of the possibilities of Asiatic development, upon which his knowledge and experience exceed those of any living writer."-Morning Post.

ANCIENT AND MODERN IMPERIALISM : An Address delivered to the Classical Association in January 1910. By the EARL of Cromer, G.C.B., O.M., G.C.M.G. Crown 8vo. 2s. 6d. net.

Mr Roosevert, in his Guildhall speech, said :- " Those of you who know Lord Cromer's excellent book in which he compares Ancient and Modern Imperialism, need no words from me to prove that the dominion of modern civilised nations over the dark places of the earth has been fraught with widespread good for mankind."

\section{THE INDUSTRIAL ORGANISATION OF AN INDIAN} PROVINCE. By TheOdore Morison, formerly Principal of the Mohammedan College at Aligarh. Demy 8 vo. 10 s. 6 d. net.

The author is mainly concerned with the condition of the masses who live by the land, and with all that affects their position, whether as agricultural labourers, yeomen, tenant farmers or payers of revenue. The literature on the subject would fill a good sized library ; but $\mathbf{M r}$ Morison approaches it from a different standpoint from that usually taken by the Indian officials.

"His opinions are expressed with lucidity and moderation, and even where they provoke dissent they demand the closest attention." -Manchester Guardian. 
LIFE AND LABOUR IN INDIA. By A. YUSUf-Ali, M.A., LL.M. (Cantab.), M.R.A.S., Barrister-at-Law of His Majesty's Indian Civil Service. With Illustrations, including Drawings by Native Artists. Demy 8vo. $12 \mathrm{~s}$. net.

"Mr Murray may be congratulated on the publication, in a handsome illustrated volume, of an interesting work. The author shows wide reading and much power of description, some pathos, and also some sense of humour. The work is very different from the ordinary British work on India, and equally different, though in another way, from the Congress works, as well as from the French works upon our Eastern Empire. The general reader will be delighted with the friendly explanation of the normal inferiority of girls to boys in the Indian social system."-Athoncum.

THE SOUTH AFRICAN NATIVES: Their Present Condition and Progress. Edited by the Soutr African Native Races Commitee. Demy 8vo. 6s. net.

"The Committee are perfectly fair and candid. They start with no prepossession except a desire to deal honestly by the natives . . . and their conclusions are modest and convincing."-Spectator.

"It is by far the fullest and most careful statement of facts relating to the Kaffirs that has yet appeared, and should command considerable attention, in view of the political reconstruction of South Africa which is now seen."-Nation.

CANADIAN CONSTITUTIONAL DEVELOPMENT : Shown by Selected Speeches and Despatches, with Introductions and Explanatory Notes. By H. E. Egerton, M.A., Fellow of All Souls' College, Beit Professor of Colonial History at Oxford; and W. L. Grakst, M.A., Beit Assistant Lecturer on Colonial History at Oxford. With Maps. Demy 8vo. 10s.6d. net.

"Our authors are sound guides, and the selection of state papers made by them merits the highest praise."-Athenoum.

"A record of constitutional history which all persons aspiring to a share in solving the great imperial questions of the day will do well to read, mark, learn, and inwardly digest . . . the book is admirable in every way . . . it will not only meet the special requirements for which it was compiled, but it will also act as a guide to knowledge in many other quarters, both in the old country and in the British Dominions beyond the Seas."-Empire Review.

JOHN MURRAY, ALBEMARLE STREET, W. 


\section{,}


RETURN TO the circulation desk of any University of California Library

or to the

NORTHERN REGIONAL LIBRARY FACILITY

Bldg. 400, Richmond Field Station

University of California

Richmond, CA 94804-4698

ALL BOOKS MAY BE RECALLED AFTER 7 DAYS

- 2-month loans may be renewed by calling (510) 642-6753

-1-year loans may be recharged by bringing books to NRLF

- Renewals and recharges may be made 4 days prior to due date

\section{DUE AS STAMPED BELOW IJAN 062003}

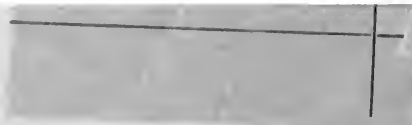




\section{YB 61489}

\section{HC 254 i 5}

220831

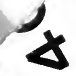

U.C. BERKELEY LIBRARIES |||||||||||||||||||||||||||||||||||||||||||

C006086392 


\section{(t)

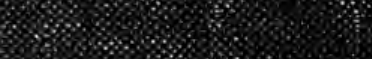

$8 \% 0 \%$

$28 \%$

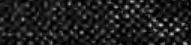

$8 \%$

$8 \% 8$

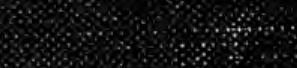

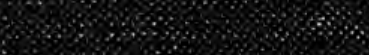

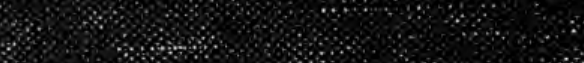

$8+2+8$

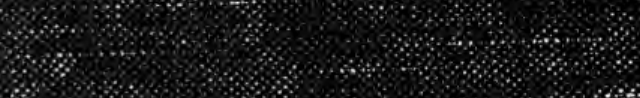

\%

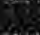

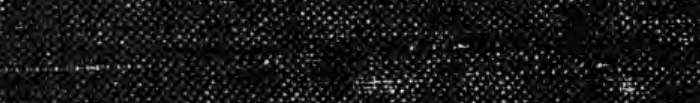

m

$300398 \%$

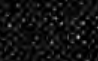

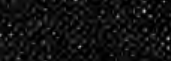

$803 \%$

$3 \%$

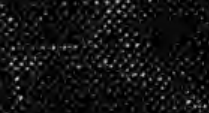

$* *+2 \%+2 \%$

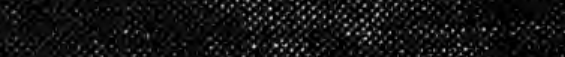

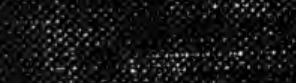

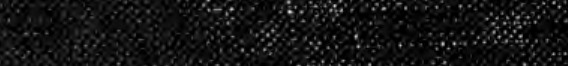

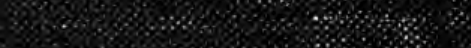

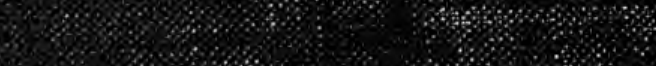

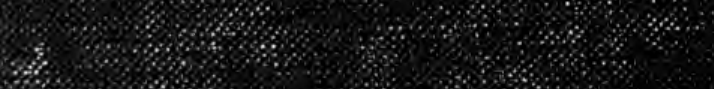

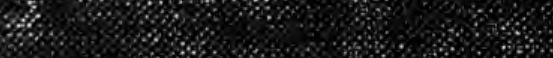

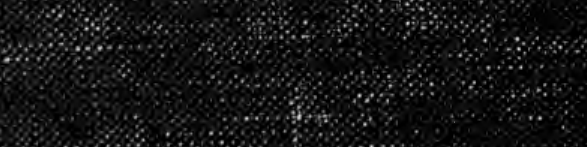

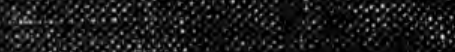

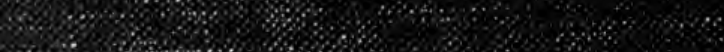

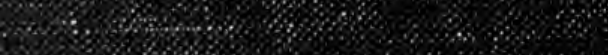

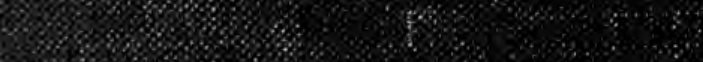

$80 \% 3 \% 3 \%$ 